UNIVERSIDADE DE SÃO PAULO

FACULDADE DE FILOSOFIA, LETRAS E CIÊNCIAS HUMANAS DEPARTAMENTO DE LETRAS CLÁSSICAS E VERNÁCULAS PROGRAMA DE FILOLOGIA E LÍNGUA PORTUGUESA

ESTUDO PALEOGRÁFICO E EDIÇÃO SEMIDIPLOMÁTICA DE MANUSCRITOS DO CONSELHO ULTRAMARINO (1705-1719)

Phablo Roberto Marchis Fachin 
UNIVERSIDADE DE SÃO PAULO

FACULDADE DE FILOSOFIA, LETRAS E CIÊNCIAS HUMANAS

DEPARTAMENTO DE LETRAS CLÁSSICAS E VERNÁCULAS

PROGRAMA DE PÓS-GRADUAÇÃO DE FILOLOGIA E LÍNGUA PORTUGUESA

\section{ESTUDO PALEOGRÁFICO E EDIÇÃO SEMIDIPLOMÁTICA DE MANUSCRITOS DO CONSELHO ULTRAMARINO (1705-1719)}

Phablo Roberto Marchis Fachin

Dissertação apresentada ao Programa de Pós-Graduação em Filologia e Língua Portuguesa, do Departamento de Letras Clássicas e Vernáculas da Faculdade de Filosofia, Letras e Ciências Humanas da Universidade de São Paulo, para obtenção do título de Mestre em Letras.

Orientador: Prof. Dr. Heitor Megale

São Paulo

2006 
Aos meus pais, Elvira e Fachim, exemplos de vida, e à Janaina Mantelli, namorada e companheira em todos os momentos 


\section{AGRADECIMENTOS}

A Fundação de Amparo à Pesquisa do Estado de São Paulo (FAPESP) pela bolsa concedida durante o mestrado.

Ao Prof. Dr. Heitor Megale pela orientação precisa e sempre presente em todos os momentos da pesquisa.

Aos Profs. Drs. Sílvio de Almeida Toledo Neto e Manoel Mourivaldo Santiago Almeida pela importante contribuição na Qualificação e durante o andamento da pesquisa.

Por fim, mas não menos importante, agradeço a todos os meus familiares pela ajuda, compreensão e incentivos constantes. 


\title{
RESUMO
}

Edição semidiplomática de documentos manuscritos do século XVIII (1705-1719) lavrados pelo Conselho Ultramarino, com vistas a oferecer edição confiável para a pesquisa em História da Língua Portuguesa e Lingüística Histórica. Trata-se de estudo baseado em critérios paleográficos que busca oferecer subsídios para a escrita desse século, visto que a bibliografia a respeito é muito escassa. Este trabalho está dividido em três partes: 1) descrição do corpus e comentário sobre o provável escriba dos documentos do Conselho Ultramarino; 2) caracterização da escrita presente no corpus, seu processo de leitura e levantamento detalhado do alfabeto, com descrição do processo de formação de cada letra e classificação das abreviaturas; 3) edição semidiplomática dos documentos.

Palavras-chave: Filologia, Paleografia, Conselho Ultramarino, manuscritos, edição semidiplomática.

\begin{abstract}
Semidiplomatic edition of manuscripts documents of XVIII century (1705-1719), cultivated by the Conselho Ultramarino, in Portugal, with sights to offer trustworthy edition for the research in Portuguese Language and Historical Linguistic. One is about study based on paleographical criteria that it searches to offer subsidies for the writing of this century, since the bibliography the respect is very scarce. This work is divided in three parts: 1) description of the corpus and brief explanation about the probable scribe of documents of the Conselho Ultramarino; 2) characterization of the present writing in the corpus, its process of reading and the detailed survey of the alphabet, with description of the process of formation of each letter and classification of abbreviations; 3 ) the semidiplomatic edition of documents.
\end{abstract}

Key words: Philology, Paleography, Conselho Ultramarino, manuscripts, semidiplomatic edition. 


\section{SUMÁRIO}

Introdução 7

\section{Primeira parte}

O corpus e o provável escriba dos documentos do Conselho Ultramarino

1 O corpus

2 O provável escriba dos documentos do Conselho Ultramarino 18

\section{Segunda parte}

A escrita presente no corpus, o seu processo de leitura e o estabelecimento do alfabeto

1 A escrita presente nos documentos do Conselho Ultramarino

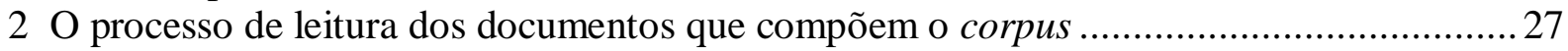

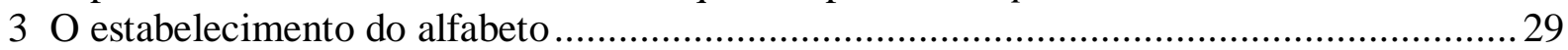

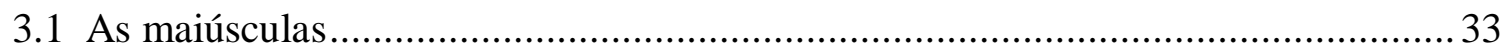

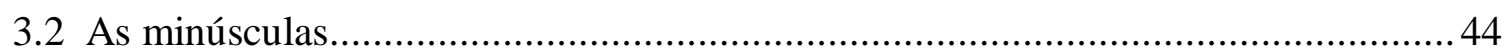

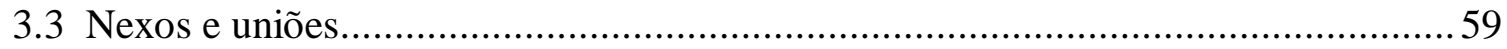

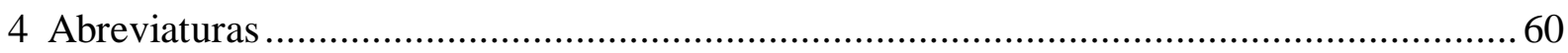

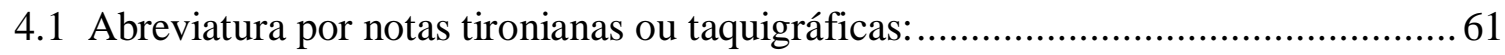

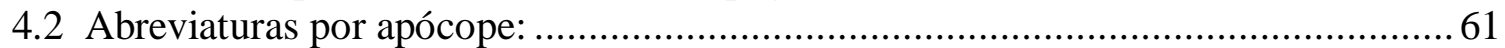

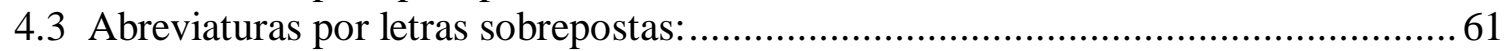

\section{Terceira parte}

A edição semidiplomática dos documentos do Conselho Ultramarino

1. Normas para transcrição de manuscritos para a História do Português do Brasil. 64

2. A edição semidiplomática dos documentos do Conselho Ultramarino 


\section{Introdução}

O objetivo desta dissertação é a edição semidiplomática de documentos manuscritos do século XVIII (1705-1719) lavrados pelo Conselho Ultramarino, com vistas a oferecer edição confiável para a pesquisa em História da Língua Portuguesa e Lingüística Histórica. Acompanha a edição a análise paleográfica da escrita presente nesses documentos, composta pelo levantamento meticuloso de seu alfabeto e pela descrição detalhada do processo de formação de cada letra. Trata-se de estudo baseado em critérios paleográficos que busca oferecer subsídios para a escrita desse século, visto que a bibliografia a respeito é muito escassa. Assim, o método de trabalho que levou ao estabelecimento da lição de cada um dos manuscritos pode vir a ser de alguma utilidade para quem encontrar pela frente letra com grau de dificuldade semelhante ou superior à da encontrada nesses documentos.

Este trabalho está dividido em três partes: 1) o corpus e o provável escriba dos documentos do Conselho Ultramarino; 2) a escrita presente no corpus, o seu processo de leitura e o estabelecimento do alfabeto; 3) a edição semidiplomática dos documentos do Conselho Ultramarino.

Na primeira parte, descreve-se o corpus da pesquisa, explica-se a sua tipologia, apresentando o glossário das espécies documentais e traz a tabela dos documentos com a indicação de suas datações cronológica e tópica. Com base no regimento do Conselho Ultramarino e em obras que trataram desse tema, discute-se, também, sobre o seu provável escriba.

Na segunda parte, caracteriza-se a escrita presente nesses documentos, comparam-se, brevemente, as suas características com as da escrita de mãos inábeis levantadas por Marquilhas (2000), em sua obra A faculdade das letras, e descreve-se o processo de leitura que levou à edição dos documentos em questão. O estabelecimento da escrita presente no corpus está dividido em maiúsculas e minúsculas. Cada letra conta com uma ocorrência 
retirada dos manuscritos como modelo do traçado de seu ductus; outras foram selecionadas para exemplificar as variações que podem sofrer de acordo com as particularidades da escrita do punho em questão, seguidas da palavra de onde foram retiradas e de sua lição. Acompanha esses dados o levantamento dos nexos e das abreviaturas.

$\mathrm{Na}$ terceira parte, apresentam-se as normas utilizadas na edição semidiplomática desses documentos e em seguida a edição propriamente dita, organizada de forma justalinear à imagem facsimilada de cada manuscrito.

Esse trabalho é resultado de pesquisa iniciada há quase três anos. Seu objetivo era a edição semidiplomática de documentos manuscritos da primeira metade do século XVIII (1704-1724). O corpus era composto por manuscritos referentes à Capitania de São Paulo, catálogo de Alfredo Mendes Gouveia, existentes no Arquivo Histórico Ultramarino / Instituto de Investigação Histórica Tropical, de Lisboa. Tratava-se de quarenta e um documentos, compostos por cento e trinta e quatro fólios. O primeiro datava de 24 de janeiro de 1704 e o último, de 19 de agosto de 1724. A sua tipologia documental abrangia alvarás, autos, autuações, bilhetes, cartas, certidões, despachos, informações, listas, mandados, ordens, pareceres, provisões, reconhecimentos, representações, requerimentos e termos de assentada. Todos esses documentos foram lidos e editados.

No decorrer do processo de edição, um conjunto de manuscritos com um tipo de letra de difícil leitura demandou mais tempo, método e trabalho do que os demais documentos propriamente ditos. Trata-se de um único punho, provavelmente de um funcionário de uma das instituições mais importantes da administração colonial, o Conselho Ultramarino. A dificuldade se deveu mais em razão da grafia do escriba do que do estado de língua, do papel ou da tinta. Dos 41 documentos selecionados para a pesquisa, 13 possuíam esse tipo de letra, em forma de anotações à margem, despachos e alguns pareceres, ou como informação principal, ocupando todo o fólio, como as minutas. 
Criado em 1642, pelo rei D. João IV, o Conselho Ultramarino nasceu da necessidade de sanar os inconvenientes que se seguiam ao serviço real no governo das Índias e dos demais territórios ultramarinos. Essa instituição foi responsável pela produção de documentos que constituem a memória de cinco séculos da administração portuguesa sobre as colônias. Nele, encontra-se todo tipo de documentação sobre os negócios ultramarinos tratados na época.

Durante o período colonial, todo documento enviado das colônias para o rei passava primeiro pelo Conselho Ultramarino para ser lido, analisado e remetido ao monarca em forma de consultas para que fossem despachados (ACIOLI, 1994:58). O fundo do Conselho Ultramarino, existente hoje no Arquivo Histórico Ultramarino, em Lisboa, agrupa documentação de várias instituições da administração central portuguesa que superintenderam nos negócios ultramarinos, são documentos avulsos e códices, desde o século XVI até $1833^{1}$. Trata-se de material de valor inestimável para as pesquisas acadêmicas, principalmente nas áreas de História, Filologia e Lingüística Histórica.

Dada a importância dos documentos do Conselho Ultramarino para a compreensão dos negócios tratados entre Brasil e Portugal. Decidiu-se, então, por investir na leitura e transcrição desses manuscritos com o intuito de apreender as peculiaridades de seus elementos gráficos e entender a lógica da escrita do escriba em questão. Contribuiu para essa escolha a dificuldade de leitura oferecida por suas características. Muitos trechos desses documentos tinham de ser representados por meio de [legível], marcação utilizada quando há intervenção do editor, na forma indicada, nos casos de letra ou palavra não legível, ou nem eram selecionados para compor corpus quando se tratava de documento que ocupava todo o fólio ${ }^{2}$.

\footnotetext{
${ }^{1}$ Essas informações constam do Catálogo dos Códices do Fundo do Conselho Ultramarino Relativos ao Brasil Existentes no Arquivo Histórico Ultramarino (MARTINHEIRA (org.), 2001:10).

${ }^{2}$ A pesquisa inicial não foi interrompida. Muitos dos temas estudados já foram discutidos em congressos e seminários; outros, inclusive, serviram de matéria para publicação: Fachin (2006), Fachin (2005).
} 
A transcrição desses documentos envolveu rigor filológico e, principalmente, conhecimentos paleográficos. Embora a letra humanística presente em manuscritos do século XVIII, seja, em sua maioria, de fácil leitura, com características bem próximas às utilizadas no nosso tempo, dependendo da grafia do escriba, como poderá ser observado no decorrer do trabalho, de editor, o filólogo passa a decifrador, em meio a manuscritos que se transformam em verdadeiros desafios. Nesse sentido, a Paleografia funciona como principal instrumento de leitura, como afirma Martínez (1991:21), fornecendo mecanismos necessários para ler e decifrar os signos gráficos (letras, palavras, frases, signos complementares) até se chegar ao que significam em seu sentido mais elementar e simples. 


\section{Primeira parte}

\section{O corpus e o provável escriba dos documentos do Conselho Ultramarino}

\section{O corpus}

O corpus deste trabalho é composto por manuscritos avulsos referentes à Capitania de São Paulo, escritos tanto no Brasil quanto em Portugal ${ }^{3}$. Trata-se de 13 documentos, compostos por 16 fólios. O critério de seleção teve como base documentos do Conselho Ultramarino com a grafia de difícil leitura aqui estudada, pertencente, provavelmente, a um dos secretários do Conselho Ultramarino, isso porque se tratava de documentos cuja competência se devia a essa instituição, como consultas, pareceres e despachos principalmente. Constam do catálogo de Alfredo Mendes Gouveia, localizado no Arquivo Histórico Ultramarino em Lisboa e fazem parte do conjunto de documentos organizados e catalogados pela equipe do Projeto Resgate "Barão do Rio Branco". O primeiro data de 22 de julho de 1706 e o último, de 22 de julho de 1719.

Esse projeto foi coordenado pelo Ministério da Cultura do Brasil e apoiado por mais de 200 instituições, públicas e privadas. Contou com quase 100 pesquisadores e técnicos para tornar possível a busca e a reunião da documentação manuscrita colonial encontrada em Lisboa e em instituições brasileiras. Estima-se um total de 3000 rolos de microfilmes para um conjunto documental de 300000 documentos. O trabalho de coleta e ordenamento resultou na distribuição de CDs com documentação microfilmada a várias universidades do Brasil e de Portugal, e na publicação de Catálogos. Além de facilitar o seu acesso, agilizou essencialmente sua consulta e pesquisa (ARRUDA, 2000).

\footnotetext{
${ }^{3}$ A indicação das datações cronológica e tópica encontra-se na tabela de documentos (p.14).
} 
A tipologia documental dos manuscritos em questão abrange cartas, consultas (minutas), despachos, pareceres (alguns são minutas), representação e requerimentos. Para que se possa ter idéia da estrutura e finalidade de cada um desses documentos, segue descrição de sua tipologia, de acordo com Bellotto (2000:305-315), retirada do glossário das espécies documentais, presente no catalogo de documentos manuscritos avulsos da Capitania de São Paulo (ARRUDA,2000), publicado pela equipe do projeto em questão.

Tabela 1. Glossário das espécies documentais que constam do corpus

\begin{tabular}{|c|c|}
\hline Carta & $\begin{array}{l}\text { (documento não diplomático, porém de desenho mais ou menos } \\
\text { oficializado, ascendente, descendente ou horizontal) }[\ldots] \text { Questões de } \\
\text { caráter oficial ou particular, que se desejasse expor ao Rei, quaisquer que } \\
\text { fossem os assuntos, não tendo o caráter peditório, eram-lhe dirigidas por } \\
\text { meio de carta. [...]. (p.307) }\end{array}$ \\
\hline Consulta & $\begin{array}{l}\text { (documento não-diplomático informativo opinativo, enunciativo, } \\
\text { ascendente) Ato pelo qual uma instituição ou indivíduo, em cumprimento } \\
\text { de um preceito genérico ou específico da autoridade máxima, no caso, o } \\
\text { Rei, o assessora em um assunto determinado. Por extensão, recebia o } \\
\text { nome de consulta o documento que o indivíduo ou instituição transmitia } \\
\text { ao soberano seu conselho em alguma questão que lhe havia sido } \\
\text { encomendada. Ato [...] pelo qual o Conselho Ultramarino assessora o Rei } \\
\text { em assuntos coloniais, [...] sobre determinado assunto. [...]. (p.309) }\end{array}$ \\
\hline Despacho & $\begin{array}{l}\text { (documento diplomático informativo-opinativo, horizontal entre } \\
\text { autoridades) - Manifestação escrita de autoridade sobre assuntos de sua } \\
\text { competência, submetidos à sua apreciação em autos ou em papéis } \\
\text { administrativos. Podem ser independentes ou fazer parte de outro } \\
\text { documento, como no caso das consultas do Conselho Ultramarino. (p.310) }\end{array}$ \\
\hline Parecer & $\begin{array}{l}\text { (Documento diplomático informativo enunciativo, horizontal) - Opinião } \\
\text { técnica sobre um ato. O parecer serve de base à decisão de um assunto, } \\
\text { orientado-a ou facilitando o processo decisório. Difere da informação, pois }\end{array}$ \\
\hline
\end{tabular}




\begin{tabular}{|l|l|}
\hline \multirow{7}{*}{ Representação } & $\begin{array}{l}\text { o parecer visa a interpretar e apreciar fatos; a informação visa a fornecer } \\
\text { fatos ou dados sobre fatos. No caso do Conselho Ultramarino, podem } \\
\text { ocorrer isoladamente ou fazendo parte de consultas. (p.313) }\end{array}$ \\
\hline Requerimento & $\begin{array}{l}\text { (Documento diplomático informativo ascendente) - Correspondência } \\
\text { apsinada coletivamente, [...] apresentada a qualquer autoridade } \\
\text { para solicitar algo a uma autoridade pública e que, ao contrario da petição, } \\
\text { está baseado ema tos legais ou em jurisprudência. Muitas vezes, o o } \\
\text { requerimento faz menção a estes atos que toma por base jurídica. (p. 314) }\end{array}$ \\
\hline
\end{tabular}

O assunto que gerava cada documento e lhe dava nome vinha escrito na posição central do fólio, parte denominada mancha. Nas margens, poderia vir escrito outro, geralmente, do Conselho Ultramarino. Como os secretários dessa instituição eram responsáveis pela escrita da maioria desses documentos marginais, despacho e pareceres principalmente, e é neles que se encontra a escrita estudada. Independente de sua posição, tratava-se de conteúdo relevante para o entendimento e a conclusão da matéria ali discutida, referentes a processos que ocorriam no Brasil e em Portugal e serviam de base para, ou eram, decisões reais. Daí o porquê de determinadas cartas, consultas, requerimentos, entre muitos outros documentos, trazerem, à margem do fólio, despachos, resoluções e pareceres, comunicando as decisões tomadas sobre o assunto ali em questão.

Megale (1998:3) já chamava a atenção para o interesse que esses documentos marginais vinham despertando durante pesquisas filológicas:

Os trabalhos que vimos freqüentando ao longo dos últimos anos têm revelado tendência nitidamente marcada pela preocupação em não se deixar perder nenhum dos traços da fonte primária no ato de transcrição, diria mais: mesmo as anotações à margem ou nas entrelinhas, bem como informações consideradas alheias ao conteúdo do texto passam a despertar interesse. 
Os documentos que compõem o corpus foram organizados cronologicamente numa tabela, onde após o número de ordem, seguem a datação em ano, mês e dia, a sua tipologia, a sua procedência, o número de fólios que o compõem e a indicação da página onde se encontram nesta dissertação. Optou-se por indicar em primeiro plano a datação que se refere aos documentos do Conselho e, entre parênteses, a do documento principal do fólio, quando aqueles vinham nas margens. O mesmo foi feito com a indicação do local onde foram escritos e com a da tipologia documental. Quando não há datações tópica e cronológica no principal, essa ausência é marcada com um ponto de interrogação, também entre parênteses.

A indicação do primeiro documento, por exemplo, deve ser entendida da seguinte maneira: despacho (com a grafia estudada), escrito em 22 de julho de 1706 em Lisboa, acompanha uma carta, escrita em 28 de outubro de 1705 em São Paulo.

Tabela 2. Documentos que compõem o corpus

\begin{tabular}{|c|c|c|c|c|c|}
\hline $\mathbf{N}^{\circ}$ & Datação & Tipologia & Procedência & Fólios & Pág. \\
\hline 1 & $\begin{array}{l}\text { 1706, julho } 22(1705, \\
\text { outubro 28) }\end{array}$ & Despacho (Carta) & Lisboa (São Paulo) & 2 & 68 \\
\hline 2 & $\begin{array}{l}\text { 1710, março } 21 \\
(1709, \text { agosto } 27)\end{array}$ & $\begin{array}{l}\text { Despacho } \\
\text { (Representação) }\end{array}$ & Lisboa (São Paulo) & 1 & 74 \\
\hline 3 & 1710, março 31 & $\begin{array}{l}\text { Minuta de Consulta } \\
\text { Parecer }\end{array}$ & Lisboa & 2 & 76 \\
\hline 4 & 1710, abril 1 & $\begin{array}{l}\text { Minuta de Consulta } \\
\text { e Parecer }\end{array}$ & Lisboa & 2 & 84 \\
\hline 5 & $\begin{array}{l}\text { 1710, dezembro } 20 \\
(?)\end{array}$ & $\begin{array}{l}\text { Despacho } \\
\text { (Requerimento) }\end{array}$ & Lisboa (São Paulo) & 1 & 92 \\
\hline 6 & $\begin{array}{l}\text { 1711, junho } 6(1710, \\
\text { outubro 12) }\end{array}$ & Despacho (Carta) & $\begin{array}{l}\text { Lisboa (V. de Santo } \\
\text { Ant. de Guaratinguetá) }\end{array}$ & 1 & 96 \\
\hline 7 & $\begin{array}{l}\text { 1711, agosto } 3(1710, \\
\text { setembro } 8)\end{array}$ & Despacho (Carta) & Lisboa (Santos) & 1 & 100 \\
\hline
\end{tabular}




\begin{tabular}{|c|l|l|l|c|c|}
\hline 8 & 1712, março 9 & Minuta de Parecer & Lisboa & 1 & 102 \\
\hline 9 & \begin{tabular}{|l|l|l|}
1712, junho 10 \\
10
\end{tabular} & $\begin{array}{l}\text { Minuta de Consulta } \\
(1713, \text { setembro 1) }\end{array}$ & Lisboa & 1 & 106 \\
\hline 11 & 1718, agosto 9 (?) & $\begin{array}{l}\text { Despacho } \\
\text { (Requerimento) }\end{array}$ & Lisboa Ocidental (?) & 1 & 112 \\
\hline 12 & $\begin{array}{l}1718, \text { julho 8 (?) } \\
\text { (Requerimento) }\end{array}$ & $\begin{array}{l}\text { Lisboa Ocidental (São } \\
\text { Paulo) }\end{array}$ & 1 & 114 \\
\hline 13 & $\begin{array}{l}1719, \quad \text { agosto } \\
(1719, \text { agosto 6) }\end{array}$ & $\begin{array}{l}\text { Despacho (Carta) } \\
\text { Lisboa (Santos) }\end{array}$ & 1 & 116 \\
\hline
\end{tabular}

Como exemplo da estruturação dos documentos nos fólios, segue requerimento de João Ferreita a D. João V, sem datação, pedindo que lhe mande passar carta de confirmação da mercê de meia légua de terra de sesmaria no sítio de Caetê. Sobre ele, recaíram dois despachos do Conselho Ultramarino, um de 9 de agosto de 1718, outro de 13 de agosto do mesmo ano, e um parecer do procurador da fazenda, sem datação. O primeiro, na margem superior; o parecer, na margem direita e o segundo despacho, na parte inferior. 


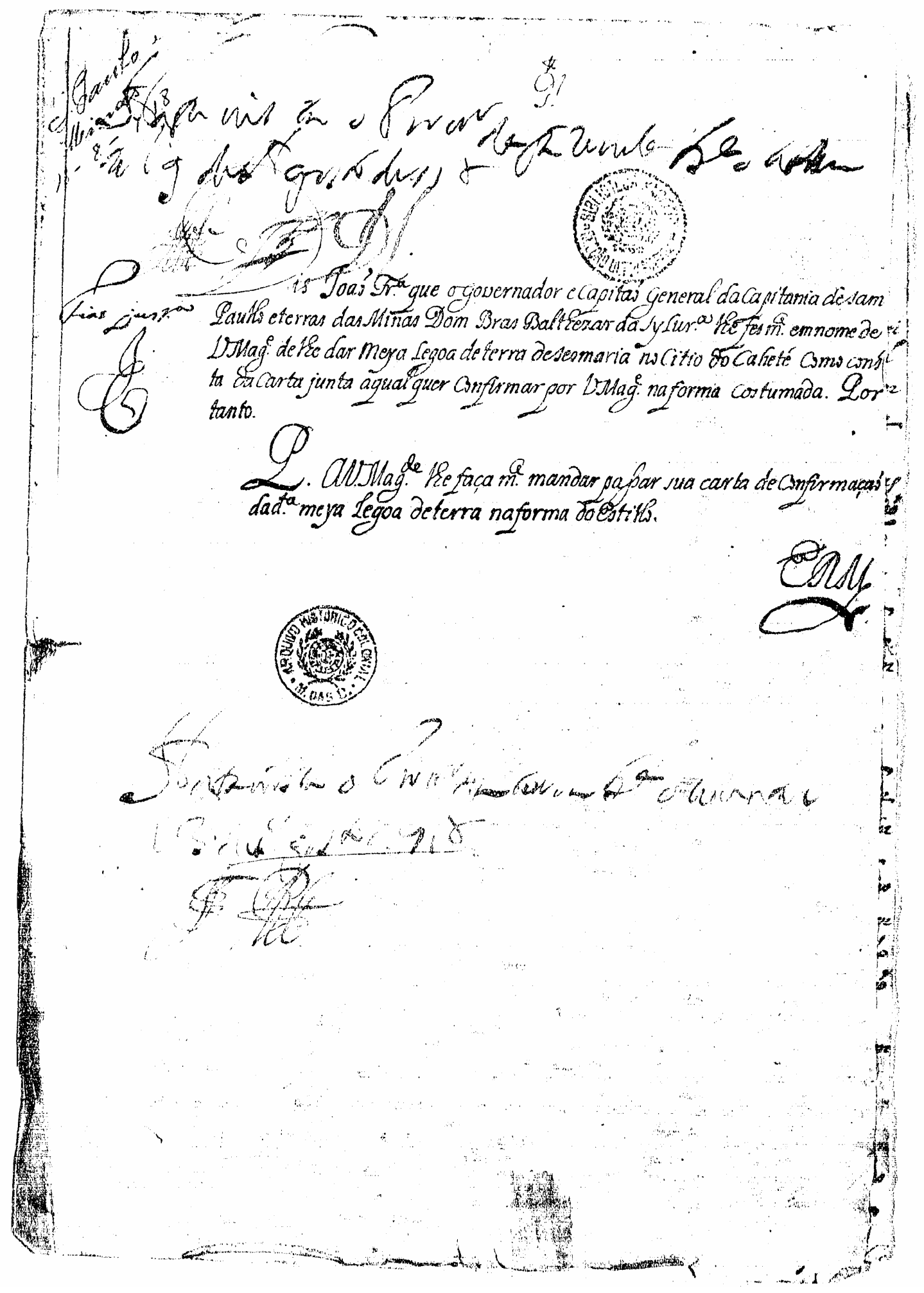

Figura 1: Despachos e parecer de 1718 acompanhando requerimento sem datação. 


\section{Senhor ${ }^{4}$}

$<$ Haja uista o Procurador da fazenda Lisboa ociden

tal 9 deAgosto de718 >

Dis Ioaõ Ferreira que oGouernador e Capitaõ General da Capitania deSam

5 Paullo e terras das Minas Dom Bras Balthezar da Sylueira lhe fes merce em nome de ${ }^{6}$ VossaMagestade de lhe dar meya Legoa de terra deSesmaria no Citio do Caheté Como cons ta da Carta junta a qualquer Confirmar por VossaMagestade na forma Costumada. Por tanto.

Pede aVossaMagestade lhe faça merce mandar passar sua carta de Confirmaçaõ 10 da dita meya Legoa de terra na forma do Estillo.

\section{EsperaReceberMerce ${ }^{7}$}

$<$ Haja vista o Procurador da Coroa Lisboa ocidental

13 de Agosto d $[\mathrm{e}] 718^{8}>$

\footnotetext{
${ }^{4}$ Abaixo do vocativo, há uma marca do carimbo da Biblioteca Nacional. Na margem esquerda superior, há a seguinte anotação: "São Paulo | Minas | 18 - 8 - 718”.

${ }^{5}$ Seguem rubricas.

${ }^{6} \mathrm{Na}$ altura dessa linha, na margem esquerda, há a seguinte anotação, seguida de rubrica: "Fiat justitia"

${ }^{7}$ Abaixo, há uma marca redonda do carimbo do Arquivo Histórico Colonial.

${ }^{8}$ Seguem rubricas.
} 


\section{0 provável escriba dos documentos do Conselho Ultramarino}

Durante o período colonial, a tramitação de documentos entre as colônias e a metrópole se dava por meio do Conselho Ultramarino, que tinha a função de julgar toda a correspondência enviada ao rei. Nele, os papéis eram lidos, transformados em consultas e remetidos ao monarca para que fossem despachados (ACIOLI, 1994:58).

Como dito anteriormente, o Conselho Ultramarino foi criado em 1642, pelo rei D. João IV, em razão da necessidade de sanar os inconvenientes que se seguiam ao serviço real no governo das Índias e dos demais territórios ultramarinos. Tal instituição era composta por um presidente, três conselheiros (dois homens de guerra e um letrado), um secretário e dois porteiros $^{9}$. Abaixo segue trecho do regimento desse conselho, exarado pelo rei, em que se descreve parte de suas finalidades (CAETANO, 1967:120):

Ao dito Conselho hei por bem, que pertenção todas as materias, \& negocios de qualquer calidade que forem, tocantes aos ditos Estados da India, Brasil, \& Guinè, Ilhas de S. Thomé,\& Cabo Verde,\& de todas as mais partes vltramarinas [...] Ao dito conselho viraõ dirigidas todas as cartas, \& despachos,que se me enuiarem de todos os Ministros,\& Prelados,\& quaesquer outras pessoas dos ditos Estados,\& todas as vias dos ditos despachos se leuaraõ ao dito Conselho serrados $[\ldots]$

Os manuscritos que compõem o corpus deste trabalho também tiveram o mesmo destino, pois se tratava de documentos oficiais referentes à capitania de São Paulo, que tramitaram entre Brasil e Portugal. Passaram, portanto, pelas mãos dos funcionários do Conselho Ultramarino que, por sua vez, "assentaram" o que foi decidido nos próprios documentos, em forma de despachos principalmente, ou em um novo, no caso, as consultas e os pareceres.

\footnotetext{
${ }^{9}$ Essa composição, provavelmente, foi alterada com o passar do tempo devido às necessidades de dar conta do grande volume de papéis que chegavam ao Conselho Ultramarino.
} 
Não era comum assinarem esses tipos de documentos após o cumprimento das tarefas discutidas pelo conselho, principalmente no caso de secretários do Conselho Ultramarino. Por isso as únicas "pistas" que se tem do escriba dos manuscritos em questão são as rubricas que os seguem e o fato de se tratar de documentos exarados por essa instituição. De acordo com o conteúdo do regimento, porém, essas rubricas poderiam ser de diversas pessoas, dos conselheiros, do procurador da coroa, do secretário ou até do próprio rei, sem a necessidade de vir acompanhada da de seu autor material. Acioli (1994:169) traz documentação em que há uma rubrica de D. Pedro II após o despacho.

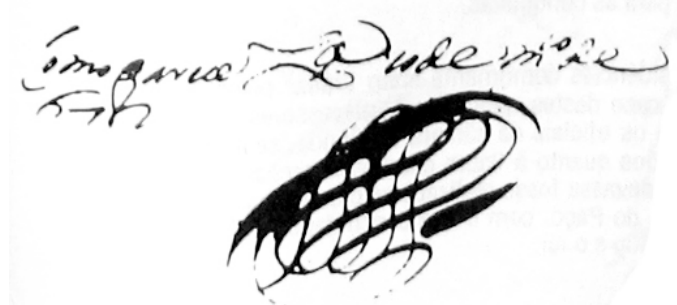

Figura 2. Despacno datado de $10 / 2$ seguido de rubrica de D. Pedro II.

Seguem as rubricas presentes nos documentos correspondentes ao Conselho Ultramarino:

Tabela 3. Rubricas presentes nos documentos do Conselho Ultramarino

\begin{tabular}{|l|l|}
\hline Rubricas & Documentos em que foram escritas \\
\hline & Doc. 1 - 1706, julho 22 - p. 68 \\
\hline & Doc. 2 - 1710, março 21 - p.74 \\
\hline & Doc. 3 - 1710, março 31 - p. 76 \\
\hline
\end{tabular}




\begin{tabular}{|c|c|}
\hline Afre & Doc. 5. - 1710, dezembro 20 - p. 92 \\
\hline 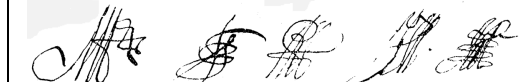 & Doc. 9 - 1712, junho 10 - p. 106 \\
\hline
\end{tabular}

Trata-se de diferentes rubricas, algumas até aparecem em vários documentos. Por causa da dificuldade em desenvolvê-las e da escassez de informações que se tem em mãos, não há como afirmar se uma delas é do escriba em questão, para que se possa buscar seus dados e pesquisar a sua biografia. Esse tipo de estudo é dificultado por vários fatores, entre eles a falta de bibliografia no Brasil a respeito dos funcionários do Conselho Ultramarino, como, por exemplo, um livro de registros com a indicação dos nomes e datas das posses dos respectivos cargos. Sem a sua identificação torna-se quase impossível a descoberta de outras informações que contribuíram relevantemente para a pesquisa.

Conforme o regimento do Conselho Ultramarino (CAETANO, 1967:120), o principal responsável pela produção dos documentos nesse órgão era o secretário. Fato que nos leva a crer que tenha sido pessoa com essa função o responsável pela produção dos manuscritos que compõem o corpus.

[...] o Secretario tomarâ em lembrança o que se assentar, em liuros,que para isso tera, \& fará as consultas,as quais seraõ rubricadas pello Presidente,\& Conselheiros todos em regra,\& as cartas, \& prouisoẽs, \& outros despachos, que elle fizer $[\ldots] \&$ o dito Secretario [...] terá muito cuidado dos negocios,\& despachos,que estiuerem a seu cargo, lendo os papeis,\& fazendo relação delles no Conselho,sem poder fallar mais,se não sendo perguntado.

Mesmo sem saber a identidade do escriba e sem ter como assegurar qual era a sua função, pode-se levantar a hipótese de que, por se tratar de um funcionário do Conselho Ultramarino, um dos órgãos mais importantes no auxílio da administração ultramar, o autor 
material desses documentos era um profissional da escrita, com papel semelhante ao de um secretário, escrivão ou tabelião, por exemplo. Provavelmente se tratava de um letrado, com manejo e habilidade nesse processo e possuidor de mecanismos de facilitação de escrita, como abreviaturas, conhecimento de linguagem formulaica, muito utilizados nesses tipos de documento.

Segundo Caetano (1967:48), "a fluência dos papéis obrigou os conselheiros a distribuir o serviço pelos vários dias da semana", o que evidencia a prática habitual de escrita que os secretários do Conselho possuíam. Daí o porquê de serem representativos de uma parte da sociedade que registrou nos manuscritos o estado de língua daquela época. 


\section{Segunda parte}

\section{A escrita presente no corpus, o seu processo de leitura e o estabelecimento do alfabeto}

\section{A escrita presente nos documentos do Conselho Ultramarino}

A escrita presente nos documentos do Conselho Ultramarino é cursiva, mas nem todas as letras se apresentem ligadas umas as outras. Possui traçado rápido e forte, aparentemente, irregular. À primeira vista, passa a impressão de falta de cuidado, com aspecto garranchoso, se comparada com a de outros manuscritos do mesmo período.

A direção da escrita é angulosa, ora está crescente, ora decrescente em relação à pauta. As letras de uma mesma palavra variam de acordo com essa oscilação, o que dificulta identificá-las em certos contextos. Tais características podem ser resultadas da velocidade empregada durante a escrita, o que também poderia ser a causa da falta de cuidado na apresentação do manuscrito, principalmente quando se tratava de minuta.

Algumas letras apresentam muita semelhança entre si. Os casos que mais chamam a atenção são $\langle\mathrm{A}\rangle|\langle\mathrm{H}\rangle,\langle\mathrm{B}\rangle|\langle\mathrm{D}\rangle \mid\langle\mathrm{R}\rangle$, $\langle\mathrm{e}\rangle \mid\langle\mathrm{i}\rangle$ e, em determinados contextos, $\langle\mathrm{f}\rangle \mid\langle\mathrm{p}\rangle$. Além de não apresentar regularidade no que diz respeito às maiúsculas e minúsculas, a cursividade da escrita do escriba proporciona tipos caligráficos rápidos e corridos, tendo como conseqüência vários nexos entre as letras, ampliando ainda mais a dificuldade de leitura. As vogais $\langle\mathrm{e}\rangle \mathrm{e}<\mathrm{i}\rangle$, por exemplo, são formadas por apenas um traço inclinado para a esquerda quando pospostas a um $\langle\mathrm{t}\rangle$.

A separação entre os elementos gráficos de uma palavra ou a falta de fronteira entre elas é outro problema que essa escrita oferece ao leitor. Seu traçado pesado, com a pena 
carregada, muitas vezes, causa um maior absorvimento da tinta pelo papel, fazendo com que a leitura do conteúdo do recto seja dificultada pelo que está no verso.

No trecho que segue, abertura de um documento de 1712, escrito em Lisboa, podem ser observadas algumas das características descritas acima:

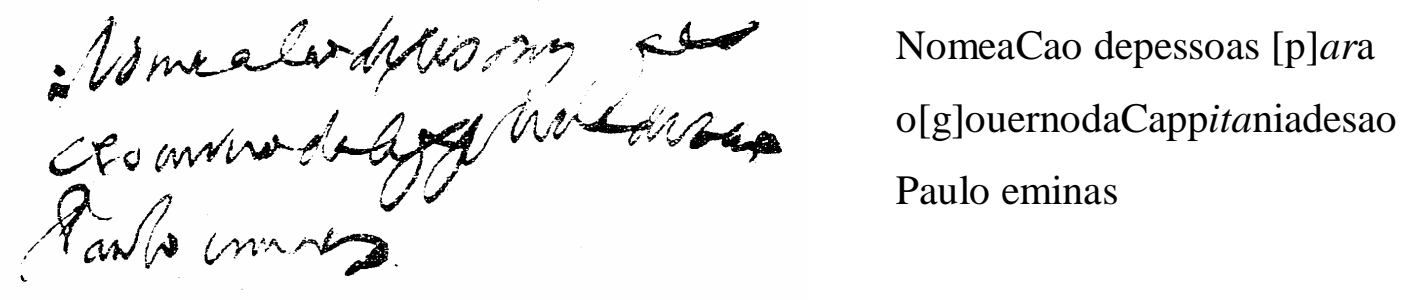

Figura 3. Abertura de minuta de parecer de 1712.

A habilidade de um escriba, teoricamente, deveria ser refletida numa escrita regular, simples e totalmente legível, portanto, de fácil leitura. Tendo em vista um regramento ideal, todas as letras deveriam ser padronizadas, ou seja, as minúsculas teriam seu corpo entre as linhas médias, suas hastes e caudas alcançariam regularmente as linhas superiores e inferiores e as maiúsculas, a parte superior desse regramento. As características da escrita presente nos documentos do Conselho Ultramarino e a dificuldade de leitura causada pela sua aparente irregularidade poderiam suscitar dúvidas a respeito da habilidade do escriba em questão.

Numa análise superficial, tal escrita poderia ser taxada como produto de mãos inábeis, expressão utilizada por Marquilhas (2000), em sua obra A faculdade das letras, para classificar a produção gráfica de indivíduos pouco familiarizados com a língua escrita. No entanto, a comparação entre as características gráficas da primeira com as das levantadas nessa obra, com certeza, mostraria que o escriba em questão não estava no mesmo nível dos 
escribas dos documentos estudados pela autora, pois, não há outras razões para acreditar que isso seja verdadeiro, senão, apenas, pela dificuldade de leitura oferecida por sua grafia.

Para designar os autores materiais dos documentos levantados em seu livro, Marquilhas utilizou o termo mãos inábeis, emprestado da expressão escripteurs maladroits, utilizada por Blanche-Benveniste (1992) em referência a indivíduos nesse mesmo patamar ${ }^{10}$. Segundo a autora (2000:237), a maneira de se reconhecer, entre os milhares de documentos arquivados pelos promotores da Inquisição, os textos das mãos inábeis seiscentistas era por meio de sua aparência física, constituída pela caligrafia de mão com falta de exercitação, causando irregularidades físicas, e por particularidades do suporte, relacionadas à frequiência de vincos devidos a uma fórmula de dobragem própria dos escritos de circulação privada bilhetes, cartas, amuletos e talismãs - a transportar junto ao corpo.

Como parâmetro de análise, Marquilhas utilizou as características levantadas pelo paleógrafo italiano Armando Petrucci (1979) que identificou sete aspectos ao analisar execução de mãos poucos exercitadas. Feitas algumas adaptações ao confrontar com os documentos da inquisição trabalhados por ela, a autora (2000:239-240) chegou aos seguintes dados caligráficos para a detecção de mãos inábeis: a) ausência de cursus: desenho autônomo de cada caractere; b) uso de módulo grande: dificuldade de integrar as letras num módulo pequeno; c) ausência de regramento ideal: incapacidade de respeitar uma pauta virtual; d) traçado inseguro, aparência desenquadrada das letras, rigidez e falta de leveza do conjunto; e) irregularidade das margens: falta de proporção entre as margens; f) letras monolíticas: desconhecimento da alografia ${ }^{11}$ combinatório dos sinais em contexto inicial, medial ou final. Abaixo seguem dois trechos de documentos produzidos por mãos inábeis levantados por Marquilhas.

\footnotetext{
${ }^{10}$ As informações sobre a utilização dessa expressão por Blanche-Benveniste foram dadas pela própria Marquilhas (2000:235).

${ }^{11} \mathrm{O}$ termo alografia se refere à presença de variantes de uma mesma letra.
} 


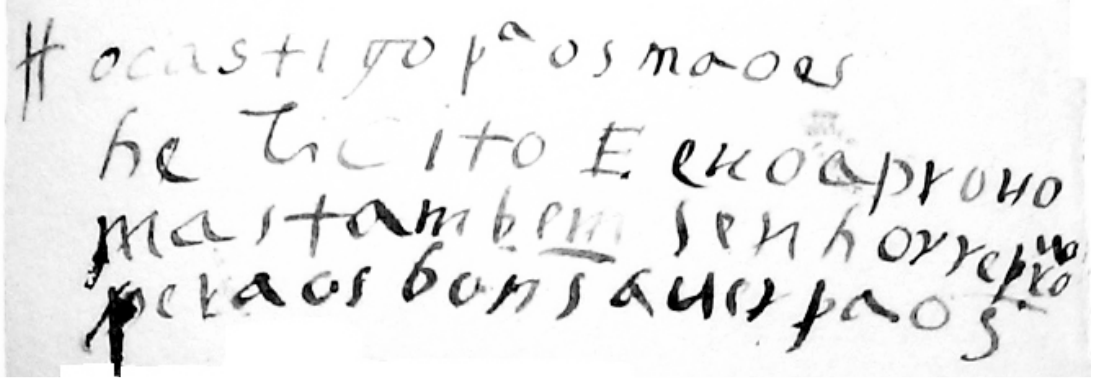

Figura 4. Quadras judaizantes enviadas à inquisição de Coimbra. (MARQUILHAS, 2000:323).

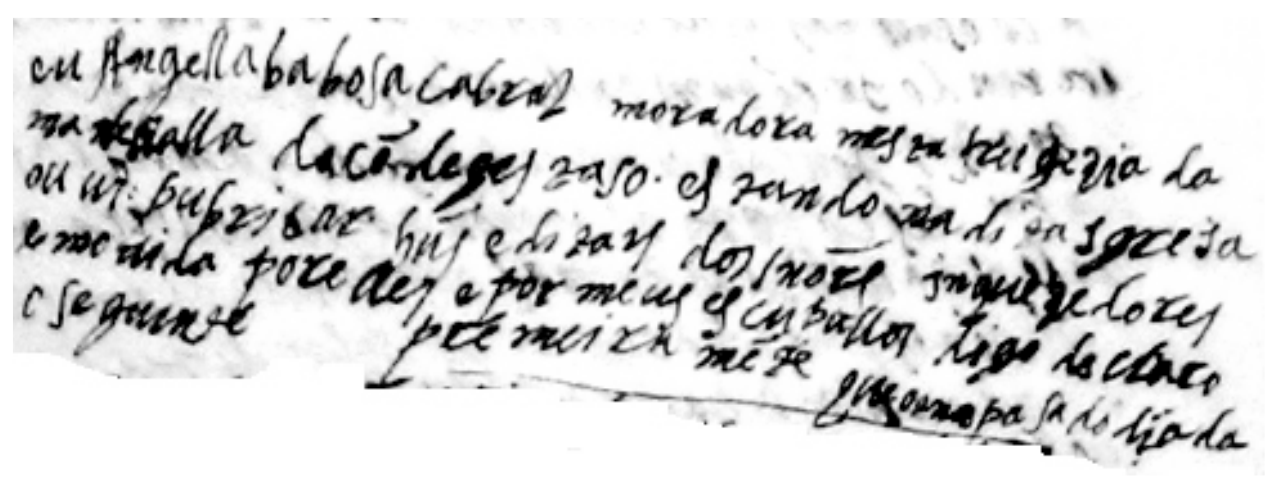

Figura 5. Trecho de denúncia particular (MARQUILHAS, 2000:343)

Embora haja características caligráficas coincidentes entre os documentos do Conselho Ultramarino e os estudados por Marquilhas, como o uso de módulo grande, pouca observância a um regramento ideal e falta de regularidade da paginação, estes se distanciam significativamente daqueles pelo seu traçado inseguro na formação das letras, em certos pontos tremido, passando a impressão de lentidão no processo de escrita, oposto ao aspecto rápido observado no punho do escriba dos documentos do Conselho.

Conhecendo-se, pelo menos como hipótese, o cargo do escriba dos manuscritos que compõem o corpus e os dados biográficos dos escribas dos documentos levantados por Marquilhas (2000:234), “indivíduos pouco familiarizados com a língua escrita”, pode-se afirmar que o aspecto aparentemente irregular da escrita pode ter influência direta, não só da 
falta de exercitação e familiaridade como é o caso dos testemunhos estudado pela autora, mas também de um processo de simplificação, decorrente, principalmente, da rapidez empregada nesse processo, em virtude da habilidade do escriba, e não o contrário, principalmente se tratando de um secretário do Conselho Ultramarino e do fluxo de trabalho de que estava encarregado. Como conseqüência o número de traços que compõem as letras pode variar, como são os casos do $\langle\mathrm{r}\rangle$ e do $\langle\mathrm{s}\rangle$, ou sofrer deformações de acordo com o contexto, como poderá ser observado de forma detalhada com o estabelecimento do alfabeto.

Tabela 4 Ocorrências gráficas retiradas do corpus

<r>




\section{O processo de leitura dos documentos que compõem o corpus}

A leitura de documentos manuscritos com vistas à edição semidiplomática, com caráter extremamente conservador, necessita de conhecimentos filológicos e critérios rigorosos. Também são necessários outros conhecimentos, principalmente, os advindos de ciências auxiliares. Dentre as que mais fornecem meios para a efetivação do trabalho filológico é a Paleografia. Por meio dela, o filólogo realiza o processo de leitura dos manuscritos, analisa-os graficamente e situa a escrita presente neles no tempo e no espaço.

Nesse processo, as letras que compõem cada palavra têm de ser identificadas e analisadas isoladamente. Uma edição confiável para servir de base para pesquisas lingüísticas é resultado de trabalho metódico, em que se utilizam princípios e procedimentos paleográficos fixados por uma das mais importantes ciências para a Filologia, que, além de funcionar como instrumento de leitura dos manuscritos, auxilia na sua interpretação.

A equipe de Tomás Marín Martínez (1991), na obra Paleografía y Diplomática, descreve detalhadamente caminho semelhante ao percorrido durante a pesquisa para o sucesso nessa tarefa. Trata-se de simples procedimento, porém muito eficaz em sua prática. Alguns dos princípios defendidos por essa equipe e que deveriam ser seguidos por qualquer editor se resumem no seguinte:

1) Observar e tentar fixar na memória as formas típicas de cada letra, isto é, sua figura e seu desenho considerados isoladamente, ou seja, com independência uma da outra. Para apreendê-las, levantará mão de livros (manuais, cartilhas, abecedários, regras etc.) de onde venham bem e facilmente reproduzidas tais letras. 
2) Uma vez apreendidas teoricamente as formas de cada letra, deve-se passar em seguida a fazer o mesmo com as figuras e desenhos correspondentes aos nexos e uniões de letras que contribuem para deformar as formas primitivas e autênticas daquelas.

3) Dar especial atenção às abreviaturas e buscar manuais e dicionários de especialistas.

4) Aplicar-se então à prática constante e ordenada de leitura, começando por conjuntos escritos mais fáceis e, gradualmente, passando aos mais difíceis.

De certo que apenas com o esquema acima não seria possível levar a cabo tarefa tão criteriosa, fez-se necessária consulta indicada no próprio exposto a manuais, cartilhas e outras obras afins. De importância particular nesse processo destaca-se o manual de paleografia de Jean Mallon (1952), Paléographie Romaine, em que explicita procedimentos bem objetivos na orientação de leitura de manuscritos e estudos de escritas.

Nos casos de textos tradicionais e curtos, com estrutura e tradição formulaica, como é a maioria dos despachos, há considerável facilitação desse trabalho. Documentos com maior extensão, por um lado, tem a sua leitura dificultada inicialmente; por outro, porém, oferecem mais elementos de comparação para o editor cumprir o seu trabalho de decifração.

Para que a leitura fosse concretizada, não houve outra sorte que realizar o levantamento detalhado do alfabeto. Para tal façanha, inicialmente, necessitava-se da seleção mínima de alguns vocábulos passíveis de identificação para então se fazer o levantamento de outros. Tentou-se, como exposto nos princípios da equipe, fixar as formas típicas de cada letra, observando seu desenho, fazendo estudo como demonstra Mallon, porém, mesmo conhecendo o seu alfabeto, não foi possível a leitura total dos manuscritos. A bem da verdade, após muitas tentativas, nem da metade deles.

Procurou-se então fazer o mesmo com as letras em contextos silábicos, uma vez que, interligadas às outras, costumam sofrer deformação em relação às suas formas primitivas. Esse levantamento ajudou consideravelmente a concretização da leitura dos documentos. Com 
ele e o alfabeto em mãos, passou-se à comparação do traçado das letras isoladamente e em contexto com as passagens que ainda não estavam identificadas. Pouco a pouco, certos enigmas foram resolvidos e chegou-se à edição, senão completa, satisfatória dos manuscritos em questão. Como consequiência, muitos dos textos, despachos e pareceres, com a mesma letra presentes em documentos menores também tiveram a sua leitura resolvida.

\section{0 estabelecimento do alfabeto}

O estabelecimento de um alfabeto representa etapa essencial para a leitura e transcrição satisfatória de qualquer manuscrito, principalmente quando se trata de grafia de difícil decifração. Trata-se de atividade que requer critério e paciência na coleta e distribuição de cada uma das letras. Nesse processo, é necessário se habituar ao tipo de escrita, a empregos de letras deformadas, trechos apagados, abreviaturas de diversos tipos, borrões e um vocabulário, muitas vezes, desconhecido.

Importante na realização dessa tarefa é o critério utilizado. Uns dos que mais se destacam nesse assunto são os procedimentos fixados por Mallon (1952). Tendo como base o que defende o autor, além da forma das letras, deve-se refazer o trabalho do escriba no processo de escrita, acompanhando exatamente a ordem em que os traços foram realizados, isto é, deve-se estudar seu ductus. Há casos em que conhecer a forma apenas não é suficiente para alcançar a sua identificação. Um "a", por exemplo, pode sofrer variações que o deixem irreconhecível em determinado contexto. Daí, a importância da noção da trajetória porque cada letra foi construída, relacionada a outros elementos de análise, como o ângulo gerado pela pena e o suporte, o módulo de cada letra (suas dimensões quanto à altura, à largura, etc) e o peso da escrita (traços fortes ou finos de acordo com o instrumento da escrita). 
Quando o trabalho baseia-se em manuscritos cuja letra já tenha sido estudada, portanto com alfabeto organizado, o paleógrafo tem mais facilidade para analisá-la e apreender suas particularidades, lançando mão de informações em manuais, cartilhas e abecedários. Embora haja pesquisadores que buscassem sistematizar o tipo de escrita do Brasil colonial, como fez Acioli (1994), contribuindo consideravelmente para esse tema, esse tipo de estudo ainda não é suficiente para dar conta da multiplicidade de punhos presentes em diversos manuscritos brasileiros e portugueses.

Como, normalmente, a leitura dos manuscritos não sai de imediato, o editor busca palavras de fácil identificação para observar, isoladamente, as formas típicas de cada letra que a compõe. À medida que tal procedimento é realizado, inevitavelmente, alcança-se o significado de outras antes desconhecidas e, assim, selecionam-se as que comporão o seu alfabeto. Trata-se de uma das tarefas mais morosas desse processo, porém, ao término, geralmente, tem-se a leitura do manuscrito quase concluída.

O estabelecimento do alfabeto apresentado tem o objetivo de compreender as particularidades da escrita do secretário do Conselho Ultramarino, autor da maioria dos manuscritos que compõe o corpus deste trabalho. Está organizado da seguinte maneira: primeiro separou-se as letras de acordo com o espaço ocupado num regramento ideal, semelhante ao de um caderno de caligrafia (segue exemplo abaixo); desse grupo formaram-se dois subgrupos: maiúsculas que, além das linhas médias, ocupam o espaço até a linha superior; e minúsculas que ocupam apenas o espaço entre as suas linhas médias e, em certos casos, chegam a alcançar a inferior e a superior por causa da haste e/u da cauda.

Para cada letra, selecionou-se uma ocorrência para servir como modelo do traçado de seu ductus; outras foram selecionadas para exemplificar algumas das variações que podem sofrer de acordo com as particularidades da escrita do punho em questão, acompanhadas da palavra de onde foram retiradas, seguidas de sua lição. Assim, espera-se reunir traçados 
suficientes para a análise das letras da grafia estudada, tanto isolada quanto em contexto. No caso das maiúsculas, em menor número, foram selecionados dois exemplos por letra; diferentemente, para as minúsculas que, em maior número, apresentam maior variação, optouse por trazer três exemplos, com exceção de algumas que não foram utilizadas nessa quantidade. Quando se julgar necessário, serão acrescentadas mais ocorrências tanto na descrição do ductus, quanto na exemplificação de sua variação.

\section{Regramento de um caderno de caligrafia ${ }^{12}$ :}

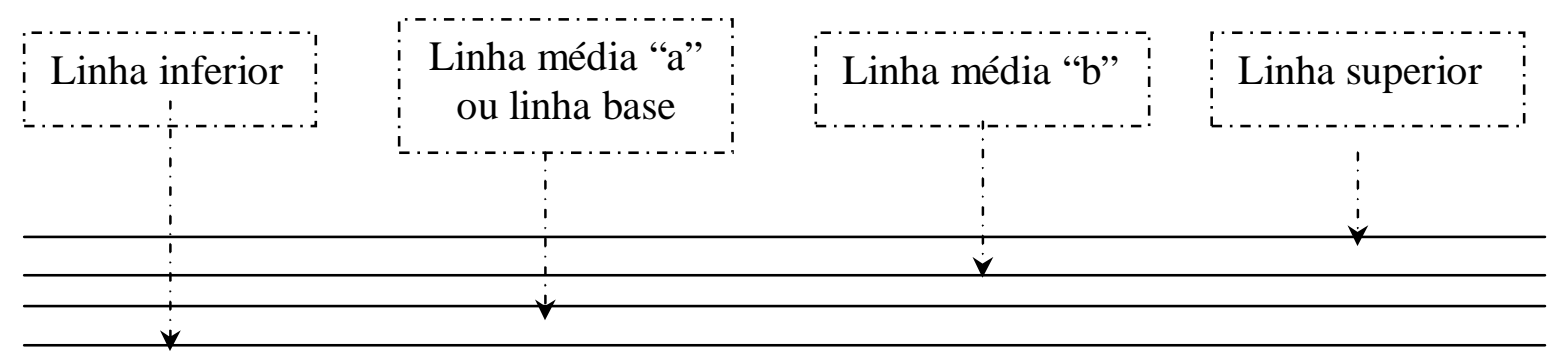

Não se pode afirmar que o escriba que produziu os manuscritos em questão fez uso de um regramento como esse, porém será de suma importância tê-lo em mente na reconstituição do processo de escrita das letras do alfabeto, pois, além de favorecer a apreensão das peculiaridades da grafia estudada, facilita a sua descrição ao ter pontos de referência que orientam o leitor no entendimento da trajetória de construção dos elementos gráficos.

Em certos casos, a identificação e a descrição das letras esbarram na semelhança gráfica entre elas e no fato de algumas serem utilizadas nos mesmos contextos, como ocorrem com as ramistas, $\langle\mathrm{i}\rangle \mid\langle\mathrm{j}\rangle$ e $\langle\mathrm{u}\rangle \mid\langle\mathrm{v}\rangle$. Por essa razão e pela necessidade de se ter um parâmetro de cada letra da época em questão para poder comparar com as encontradas no corpus,

\footnotetext{
${ }^{12} \mathrm{O}$ nome dado a cada linha desse regramento é meramente sugestivo e serve apenas como referência na orientação da formação das letras, matéria a ser tratada mais adiante.
} 
utilizou-se o alfabeto de minúsculas e maiúsculas levantado por Figueiredo (1722), em seu manual para aprender a ler, escrever e contar, escrito também no século XVIII. Seguem os alfabetos selecionados:

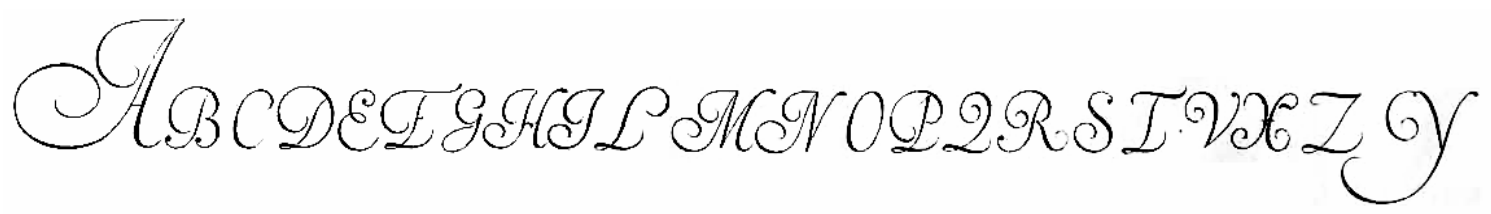

Figura 6: Alfabeto maiúsculo do século XVIII levantado por Figueiredo (1722:7)

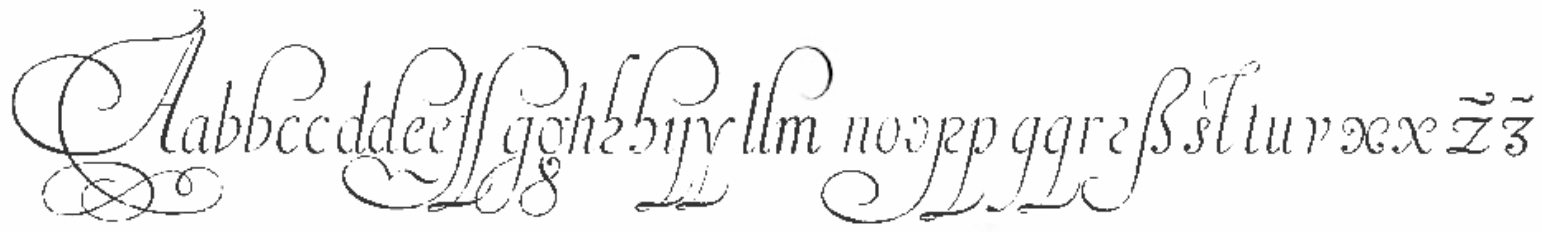

Figura 7: Alfabeto minúsculo do século XVIII levantado por Figueiredo (1722:7)

Nesse manual, Figueiredo descreve a maneira como os mestres deveriam ensinar aos principiantes a formação das letras. Mesmo tendo se limitado somente à descrição das minúsculas, esse trabalho tem grande importância para o que se pretende realizar. A contribuição dada pelo autor servirá como apoio para o estabelecimento e análise do alfabeto dos manuscritos selecionados para esta dissertação, principalmente no que diz respeito à descrição da formação das letras. Ao teorizar sobre esse assunto, Figueiredo (1722:39) afirmou que:

[...] conforme a experiencia me tem mostrado, me parece por sem duvida, que o fundamento principal de todas as fórmas de letras, consiste sómente em huma linha recta, e outra curva. Vareaõ as letras na fórma de seus caracteres no cortado das linhas, por serem humas feitas com alguma inclinaçaõ á parte esquerda, e outras a prumo, e as curvas humas ovadas, e outras em meyo circulo; porém me parece (como ja disse) consistir a formação das letras na linha recta, e curva, das quaes tomada a altura, de que 
cada hum quer fazer a letra, talhando a linha curva voltada á parte direita, e a esquerda, e a recta outro tanto para cima, e para baixo, se fórmaõ todas as letras do Abecedario, [...]

Para facilitar este estudo, a descrição das letras foi realizada com base, também, na noção de tempo e traços defendida por Mallon (1952:24-25). Segundo o autor, as letras são feitas em um ou mais tempos, cada tempo comporta um ou mais traços de acordo com o traçado utilizado na composição das letras.

É importante ressaltar que a descrição das letras que compõe o alfabeto refere-se apenas à escrita cujo responsável provavelmente pertencia ao Conselho Ultramarino e aqui caracterizada como de difícil leitura. A presente em outros documentos, como as cartas, os requerimentos, por exemplo, não é matéria de estudo deste trabalho. Vale lembrar que se trata de uma descrição interpretativa e, por isso, não está livre de equívocos inerentes a esse tipo de análise. A presença de seu ductus explicado por meio de setas que indicam a quantidade e a ordem de traços que compõe cada letra oferece ao leitor não só as particularidades dessa escrita, mas também o caminho trilhado nessa interpretação.

\subsection{As maiúsculas}

Com algumas exceções, a maioria das letras maiúsculas tem características semelhantes às das levantadas por Figueiredo (1722). Em geral, são de fácil identificação e apresentam pouca variação. O leitor encontrará mais dificuldade em identificar e distinguir as letras $\langle\mathrm{B}\rangle,\langle\mathrm{D}\rangle$ e $\langle\mathrm{R}\rangle$ pela semelhança entre elas na forma, no módulo e no ductus. Oito não foram utilizadas pelo escriba: $\langle\mathrm{F}\rangle,\langle\mathrm{G}\rangle,\langle\mathrm{J}\rangle,\langle\mathrm{O}\rangle,\langle\mathrm{Q}\rangle,\langle\mathrm{S}\rangle,\langle\mathrm{T}\rangle$ e $\langle\mathrm{U}\rangle$. Como já foi dito, cada letra será acompanhada por duas ocorrências do corpus para exemplificar seu uso, com exceção da letra $\langle E\rangle$, utilizada apenas uma vez. 


\section{Letra $\langle\mathrm{A}\rangle$ :}
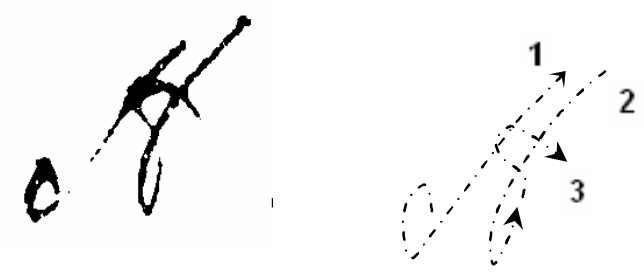

Não apresenta muita variação em seu módulo, nem em seu traçado, e é de fácil identificação, exceto pelo fato de poder ser confundida com o traçado do $\langle\mathrm{H}\rangle$, pois suas hastes não se encontram unidas na parte superior. É escrita em três tempos, cada qual com um traço. O primeiro, iniciado com uma curva volta para a esquerda na linha média "a”, sobe até a linha superior inclinadamente para a direita, onde encerra sua haste (1). O segundo começa da altura que terminou o primeiro e desce, paralelamente a esse, até a base, formando a segunda haste com uma curva no final volta para a direita (2), de onde sobe uma linha curva para a direita que unirá os dois traços por meio de outra curva voltada para a esquerda (3). Há casos, como o <A> de Antônio, mostrado abaixo, em que da própria base da segunda haste, sobe o terceiro traço encurvado para a esquerda, sem a curva para a direita observada no $\langle\mathrm{A}\rangle$ de Agosto.
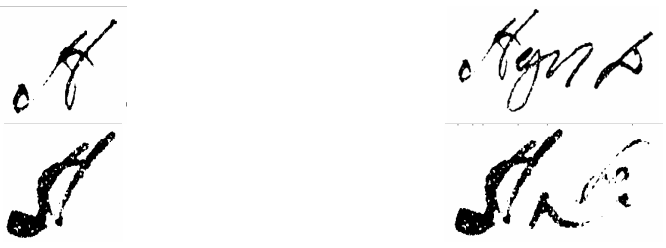

Agosto

Antonio 


\section{Letra $\langle\mathrm{B}>$ :}
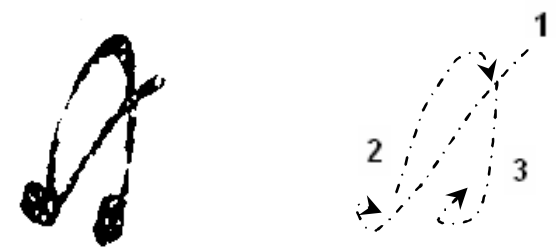

Essa letra é facilmente confundível com o $\langle\mathrm{D}\rangle \mathrm{e}$, principalmente, com o $\langle\mathrm{R}\rangle$ presentes no corpus e mostradas mais adiante, pois possuem módulos e ductus semelhantes. É formada em três tempos, por dois traços. O primeiro inicia-se próximo da linha superior do regramento e desce, inclinadamente para a direita, até a linha média "a", onde é encerrado com uma pequena curva fechada voltada para a esquerda (1). Desse mesmo ponto, no segundo tempo, inicia-se o segundo traço que é formado por uma linha que sobe, ligeiramente encurvada para a esquerda, até a linha superior, onde faz-se uma curva oval para a direita (2), e volta a descer, levemente encurvada nessa mesma direção, até a base, sendo finalizado como o primeiro, com uma linha curva fechada (3). O primeiro traço pode vir torto em determinados casos, como ocorre no $<\mathrm{B}>$ de Bras.
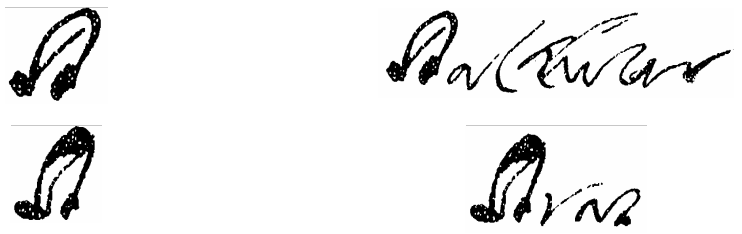

Balthezar

Bras 


\section{Letra $\langle\mathrm{C}\rangle$ :}
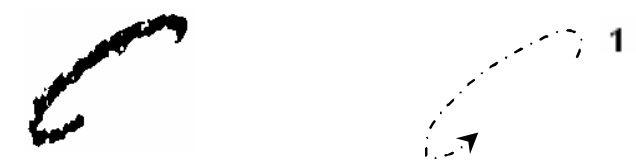

De fácil identificação, é escrita em um único tempo, com um traço apenas formado por uma linha curva voltada para a esquerda, cobre os espaços entre as linhas superior e média "a".
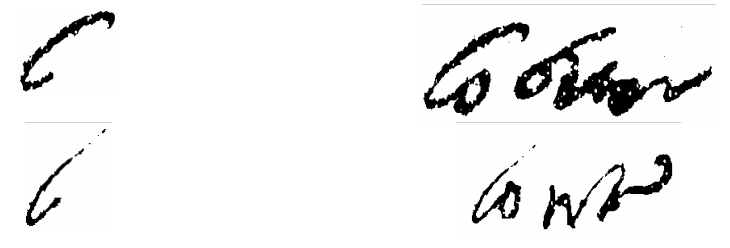

Cobrar

Conselho

\section{Letra $\langle\mathrm{D}\rangle$ :}
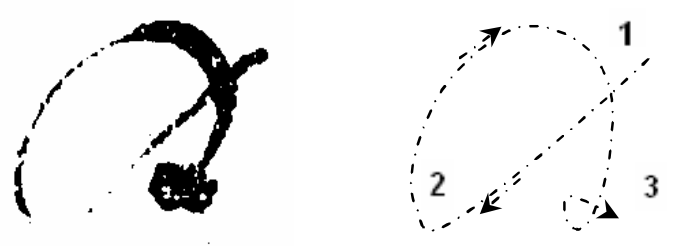

Como já foi dito anteriormente, essa e as letras $\langle\mathrm{B}\rangle$ e $\langle\mathrm{R}\rangle$ são facilmente confundíveis entre si. É formada em dois tempos, por um traço. A linha que compõe seu traço é contínua, diferente do que ocorre com $\langle$ B $>$. Talvez esse seja o principal aspecto que auxilie na distinção entre essas duas letras, o outro seria o contexto. Inicia-se como o <B>, com um traço que, inclinadamente para a direita, a partir da linha superior, desce até a base do 
regramento (1) e, em vez de ser encerrada com uma curva para o início do segundo, como ocorre com $\langle\mathrm{B}\rangle$, segue, encurvada para a esquerda, para cima continuamente até a linha superior, onde faz-se uma curva para a direita (2) e volta a descer, levemente encurvada nessa mesma direção, até a base, sendo finalizado com uma curva fechada à esquerda (3). A forma de seu primeiro traço pode variar bastante, como ocorre no $\langle\mathrm{D}\rangle$ do segundo exemplo, em que é formada pelo traçado de um $\langle\mathrm{V}\rangle$.
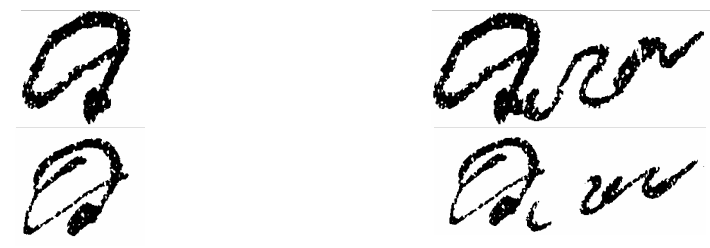

Dezembargador

Dezembargador

\section{Letra $\langle\mathrm{E}\rangle$ :}

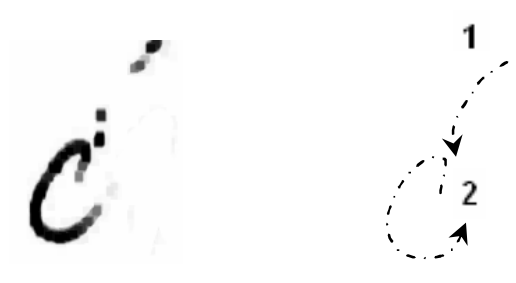

Rara no corpus, houve apenas uma ocorrência. Essa letra não se diferencia muito da levanta por Figueiredo (1722). É formada em dois tempos, cada qual com o seu traço. O primeiro na parte superior do regramento, é formado por uma linha levemente encurvada para a esquerda (1); o segundo, entre as linhas médias, por uma linha curva no mesmo sentido que o primeiro (2).

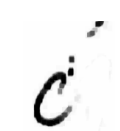




\section{Letra $\langle\mathbf{H}\rangle$ :}
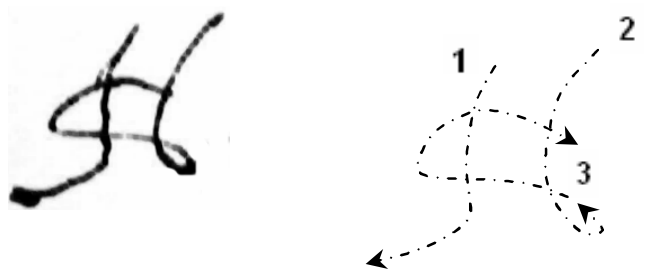

Essa letra tem forma e traçado semelhantes aos do presente no alfabeto de Figueiredo (1722). Como já citado anteriormente, também se assemelha à letra $<\mathrm{A}>$. É escrita em três tempos, com dois traços. O primeiro traço, iniciado na altura da linha superior, inclinado e levemente encurvado para a esquerda, desce, na altura da linha média "b", encurva para a direita até chegar à linha média "a”, onde encerra sua haste com a pena carregada (1). No segundo, começa também na mesma altura que o primeiro e desce, encurvado para a esquerda, até a base, formando a segunda haste com uma curva no final volta para a direita (2), de onde sobe em curva para a esquerda, unindo as duas hastes (3). Às vezes, ocorre de esse trecho não ser suficiente para fazer essa união, como pode ser observado no $\langle\mathrm{H}\rangle$ do segundo exemplo.
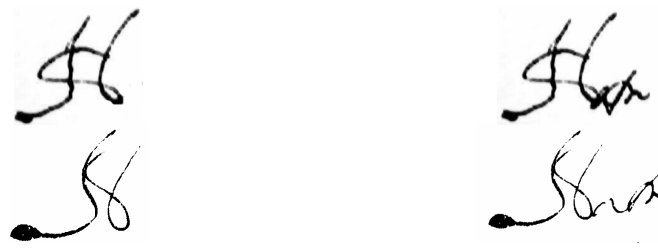

Haja

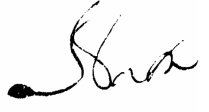

Haja

\section{Letra $<$ I $>$ :}
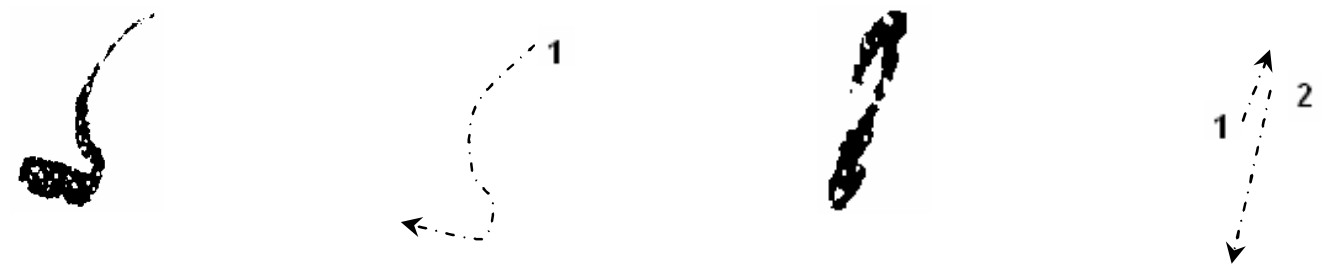
Substitui a letra $<\mathrm{J}>$ em determinados contextos, principalmente, em início de palavra. Possui duas formas. A primeira é realizada em um tempo, com um único traço que começa na linha superior, levemente encurvada para a esquerda, na altura da linha média "b", encurva-se para a direita, onde se encerra com um peso maior. A segunda tem o que Figueiredo (1722) chamou de farpa, um detalhe antes de iniciar o traço principal, que começa na altura do da forma anterior e, inclinadamente para a direita, desce até a linha média "a".

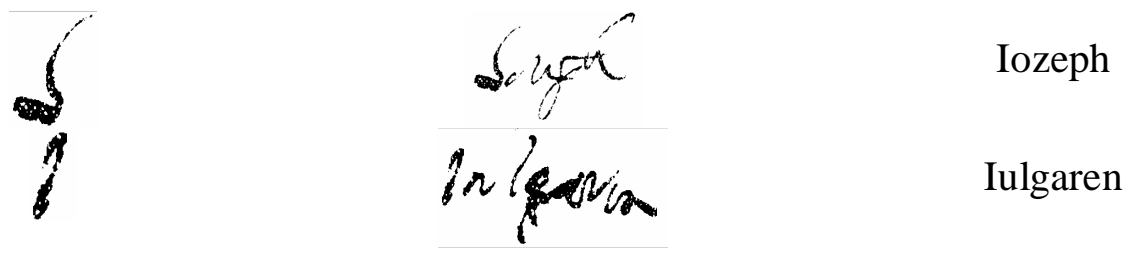

\section{Letra $\langle\mathrm{L}\rangle$ :}
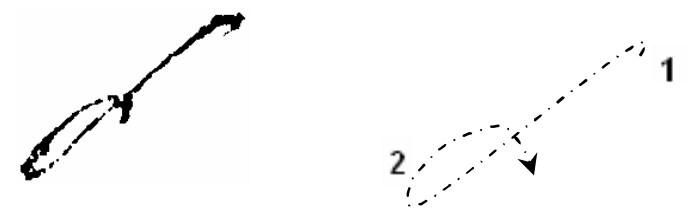

Essa letra é formada em dois tempos, por um traço contínuo. Inicia-se na altura da linha superior, um traço que, inclinadamente para a direita, desce até a linha média "a", formando a sua haste (1), de onde sobe em curva para a esquerda até cortar o primeiro na altura da linha média "b" (2). O que pode variar nessa letra é a circunferência da curva formada, como se observa entre os dois exemplos que seguem.
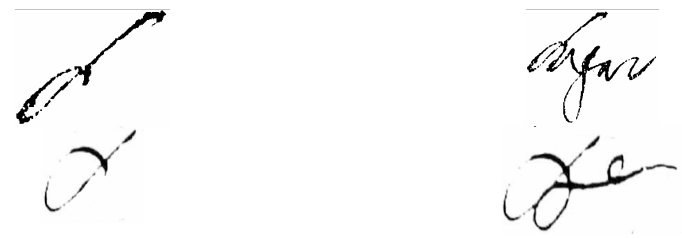

Lugar

Lisboa 


\section{Letra $\langle\mathrm{M}\rangle$ :}
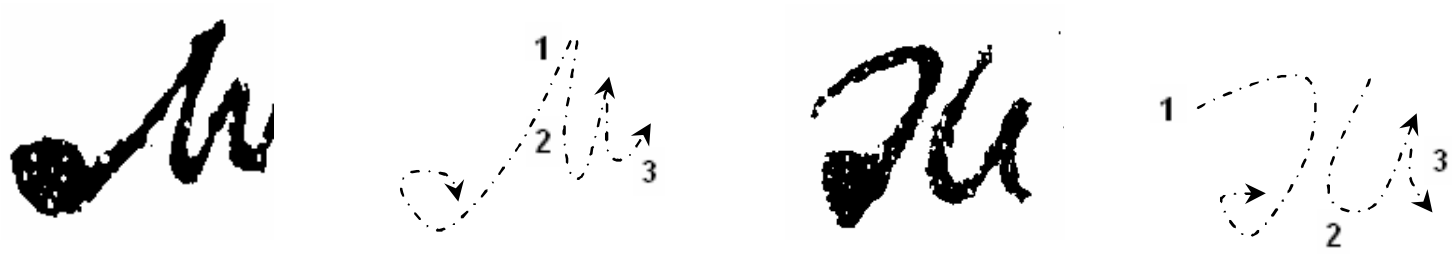

Essa letra possui uma forma com traçado semelhante ao levantado por Figueiredo (1722) e outra que difere desse modelo, encontrada mais na abreviatura de Vossa Majestade. Ambas são escritas da mesma maneira, em três tempos, cada qual com o seu traço. O primeiro inicia-se na altura da linha superior do regramento e, inclinadamente para a direita, desce até a linha média "a", onde é encerrado com uma curva fechada para a esquerda, com a pena carregada (1). O segundo, iniciado no mesmo local que o anterior, desce, levemente encurvado para a esquerda, próximo à linha média "a" e, inclinadamente para a direita, volta a subir (2). O terceiro inicia-se onde parou o anterior e, levemente encurvado para a esquerda, desce até encerrar a letra, semelhante a traço dois (3). O segundo modelo se difere do primeiro pelo fato de o traço 2 não iniciar colado ao 1 . É importante lembrar que o traçado desse outro $\langle\mathrm{M}\rangle$ é semelhante ao da letra $\langle$ s $>$, o que pode causar dificuldade em identificálos e diferenciá-los em caso de palavra de difícil leitura.
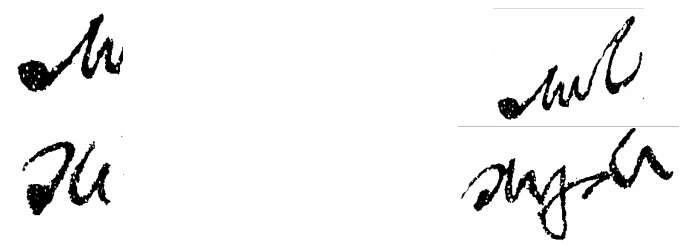

Manoel

Magestade 


\section{Letra $\langle\mathbf{N}\rangle$ :}
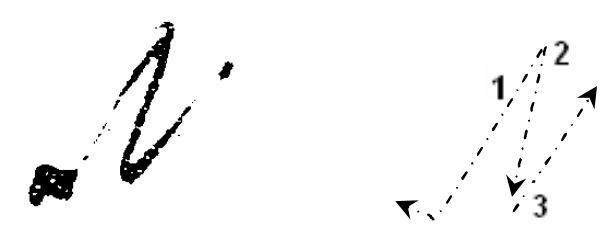

Essa letra é formada em três tempos, por dois traços. Só aparece uma vez no corpus como maiúscula. $\mathrm{O}$ primeiro é feito da mesma maneira que o traço inicial da letra $\langle\mathrm{M}\rangle$, mas com menor inclinação. Forma-se a haste (1) com um traço que desce a partir da linha superior, ligeiramente inclinado para a direita, até a linha média "a", onde é encerrada à esquerda, carregando-se a pena. $\mathrm{O}$ segundo tem o traçado de um $\langle\mathrm{V}\rangle$ inclinado para a direita; uma linha reta desce, paralela ao primeiro (2) e sobe, a partir da linha base, inclinada para a direita (3).
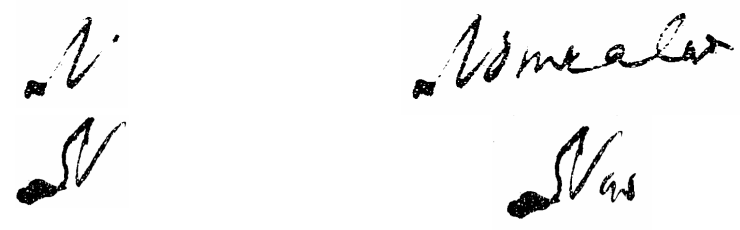

\section{NomeaCao}

$\mathrm{NaO}$

\section{Letra $\langle\mathrm{P}\rangle$ :}
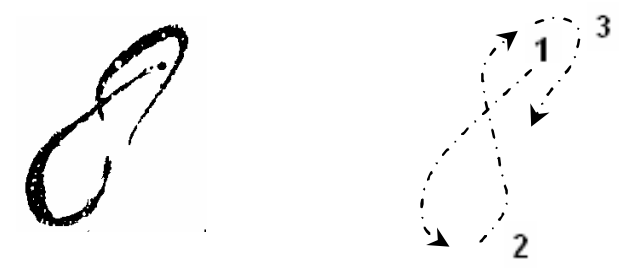

Essa letra é formada em três tempos, por apenas um traço. Parece-se, à primeira vista, com o número 8. Começa quase na altura da linha superior e, inclinadamente para a direita, desce, encurvando-se para a esquerda até chegar à linha média "a", onde gera um arco (1); 
sobe, encurvado para a direita, corta o traçado anterior e forma um outro arco (2), e volta a descer para encerrar a letra (3).
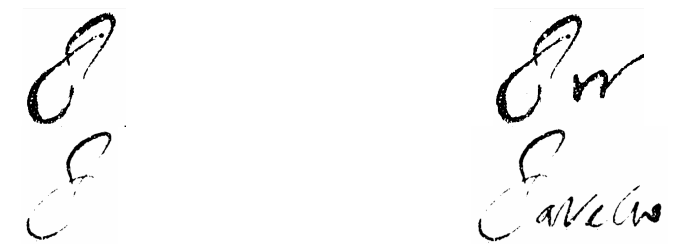

\section{Por \\ Pareceo}

\section{Letra $\langle\mathbf{R}>$ :}
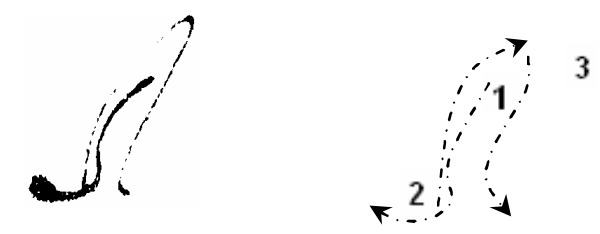

Como foi dito anteriormente, essa letra é muito parecida com o $\langle\mathrm{D}\rangle$ e, principalmente, com o $\langle\mathrm{B}\rangle$, tanto que em certos casos parecem ter o mesmo ductus. É formada em dois tempos, por três traços. O primeiro inicia-se próximo à linha superior do regramento e desce, de forma tortuosa, até a linha média "a", onde é encerrado à esquerda, carregando-se a pena (1). Desse ponto, inicia-se o segundo traço que é formado por uma linha que sobe, ligeiramente encurvada para a esquerda, até a linha superior, onde faz-se uma curva oval para a direita (2), descendo, paralelamente ao traçado que subiu, até a base, finalizando-se para a direita (3).
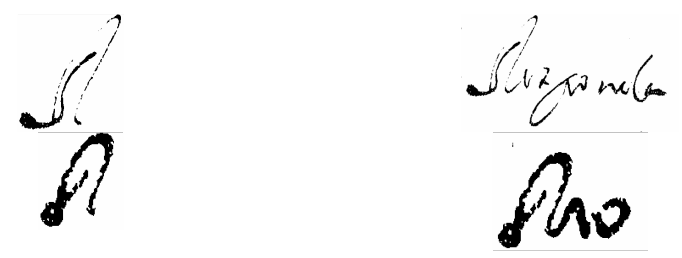

Responda

Rio 


\section{Letra $\langle\mathrm{V}\rangle$ :}
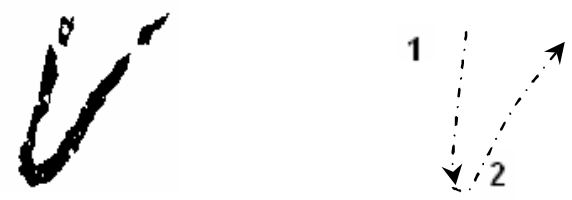

Essa letra é formada em dois tempos, por um traço. Inicia-se na linha superior do regramento e desce verticalmente até a linha média "a" (1), de onde sobe, inclinado para a direita, até a altura da linha superior (2).
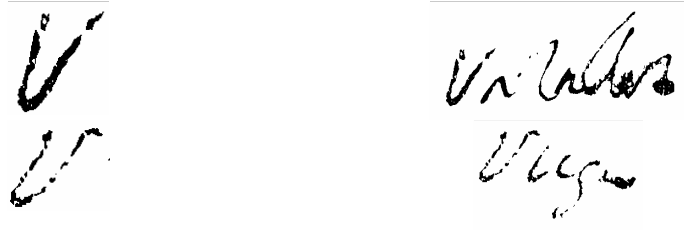

VaCallos

Veiga

\section{Letra $\langle\mathrm{Z}\rangle$ :}
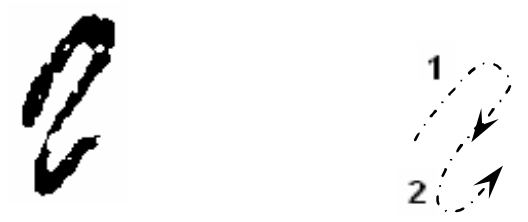

A letra $\langle Z\rangle$ é formada em dois tempos, por um traço. No primeiro tempo, próximo à linha média "b", sobe, inclinadamente para a direita, até a superior, onde faz uma curva para a direita e volta no mesmo sentido (1). No segundo tempo, nesse mesmo ponto, o traço desce inclinadamente para a direita até a linha média "a" e faz uma curva voltada para a esquerda e sobe novamente até encerrar a letra, próximo à média "b" (2).
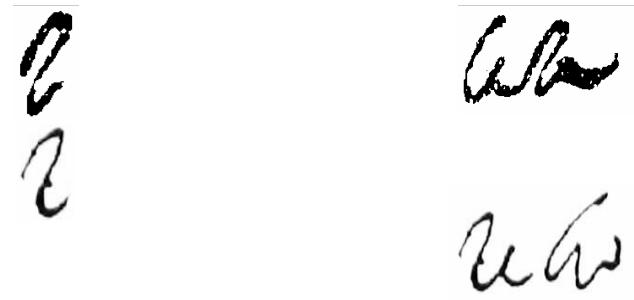

$\mathrm{CaZa}$ 


\subsection{As minúsculas}

As minúsculas estão divididas de acordo com o espaço ocupado num regramento ideal. Primeiramente serão descritas as letras cujo corpo ocupa apenas as letras médias ${ }^{13}$, vogais: $\langle\mathrm{a}\rangle,\langle\mathrm{e}\rangle,\langle\mathrm{i}\rangle,\langle\mathrm{o}\rangle,\langle\mathrm{u}\rangle$; consoantes: $\langle\mathrm{m}\rangle,\langle\mathrm{n}\rangle,\langle\mathrm{r}\rangle,\langle\mathrm{s}\rangle,\langle\mathrm{v}\rangle,\langle\mathrm{x}\rangle \mathrm{e}\langle\mathrm{z}\rangle$; seguidas das que possuem haste ou cauda, portanto, alcançando a parte superior ou inferior do regramento, as primeiras são representadas pelas letras $\langle\mathrm{b}\rangle,\langle\mathrm{d}\rangle,\langle\mathrm{h}\rangle,\langle\mathrm{l}\rangle$, as segundas, $\langle\mathrm{j}\rangle$, $<\mathrm{p}>$ e $<\mathrm{q}>$; por fim, a que, além da haste, possui cauda, ocupando todas as suas extremidades, $\langle\mathrm{f}\rangle$. Para cada letra, foram selecionados três exemplos para demonstrar as suas variações dentro do corpus. Quando a letra apresenta variação que não possa ser demonstrada por essa quantidade, foram acrescentados outros. Da mesma maneira se procedeu quando a ocorrência selecionada como modelo de ductus não dava conta da variação sofrida dentro do corpus.

\section{Letras sem haste e sem cauda}

\section{Vogais}

\section{Letra $\langle\mathbf{a}>$ :}

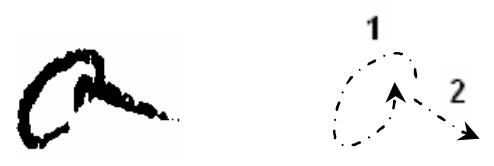

\footnotetext{
${ }^{13}$ A letra $<c>$ não está presente nessa lista, pois a sua forma apresenta-se apenas com módulo grande, portanto já descrita na parte reservada às maiúsculas.
} 
Em geral, essa letra é de fácil identificação, exceto em algumas posições, principalmente em final de palavra, pois pode aparecer deformada, isto é, seu ductus e sua forma apresentam-se diferentes dos que foram selecionados como modelo. É escrita em dois tempos. O número de traços que compõe cada um deles varia de acordo com a posição na palavra. Geralmente, no primeiro tempo, faz-se um círculo voltado para a esquerda (1) e, no segundo, encerra-se a letra com um traço que, inclinado para a esquerda, encerra a letra (2). Quando não se completa o círculo, desce verticalmente outro traço do ponto em que se iniciou o primeiro e se encerra para a direita com uma espécie de farpa, é o caso do <a> de Pareceo. Às vezes, o primeiro traço forma apenas meio círculo num primeiro tempo, necessitando de mais dois traços para concluir a letra, como se observa no <a> de sua. Em alguns casos, pode aparecer muito simplificada, formada com dois traços, mas sem chegar a completar o círculo inicial, muito menos um arco, como em algũ , podendo ser confundida com o $\langle\mathrm{e}\rangle$ ou o $\langle\mathrm{i}\rangle$, descritos mais adiante.

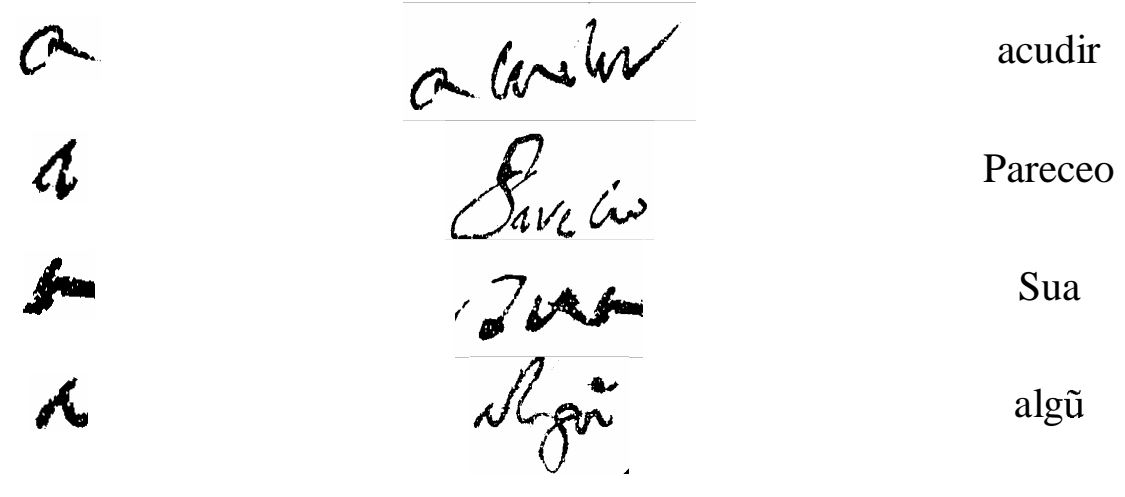

\section{Letra $\langle\mathrm{e}\rangle$ :}
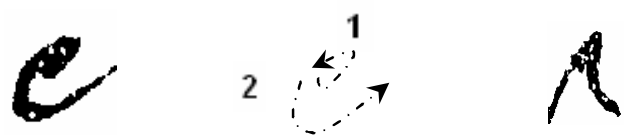

$1, i_{i}^{2}$ 
Essa letra possui duas formas no corpus, uma delas semelhante a que se observa no alfabeto de Figueiredo (1722); outra que, além de causar estranhamento por causa de sua forma, é facilmente confundível com a letra <i>. Como fenômenos de abaixamento e alçamento entre essas letras eram comuns em manuscritos da época, a sua transcrição em determinados casos se baseou em hipóteses levantadas com base no contexto e no registro moderno. A primeira forma é realizada em dois tempos por um traço. Inicia-se entre as linhas médias, por meio de um pequeno arco voltado para a direita e encerra a letra por meio de uma curva voltada para a esquerda. A segunda forma é escrita em dois tempos, por dois traços. Inicia-se na linha média "a" e sobe, inclinadamente para a direita, até a linha média "b" (1), em seguida, desce, levemente encurvado para a esquerda, até a linha em que se iniciou o primeiro (2), formando uma espécie de pirâmide. Esse 〈e〉 piramidal é encontrado, geralmente, em posições medial e final.
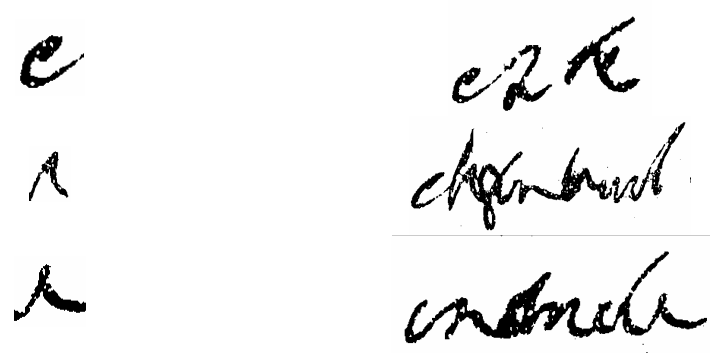

este

defenCauel

de

\section{Letra $\langle\mathbf{i}>$ :}

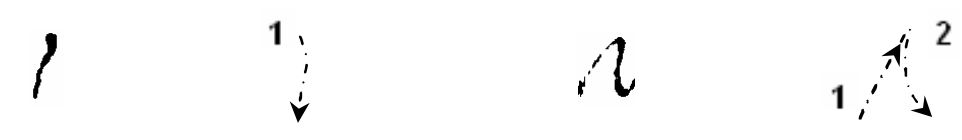


Substitui a letra “j” em determinados contextos, principalmente, em início de palavra, onde se apresenta apenas com módulo grande, portanto não será listado aqui exemplo nessa posição. Raríssimas vezes, vem acompanhada pelo pingo, o que amplia a dificuldade em diferenciá-la da letra $<\mathrm{e}\rangle$. Sua forma oscila entre a realizada com apenas um traço vertical (1), como vista em Pimentel, e a forma piramidal semelhante ao <e〉, presente em Cappitania, realizada em dois tempos e com dois traços: inicia-se na linha média "a" e sobe, inclinadamente para a direita, até a linha média "b" (1), em seguida, desce, levemente encurvado para a esquerda, até a linha em que se iniciou o primeiro (2).
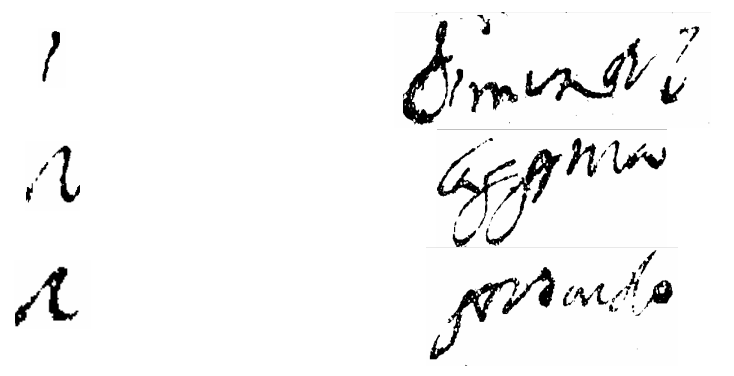

\author{
Pimentel \\ Cappitania \\ prouido
}

\title{
Letra $\langle\mathbf{0}\rangle$ :
}

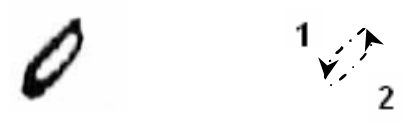

Quando se encontra em início de palavra e fechada, seu corpo é formado em dois tempos, com um único traço. Primeiro, é feito um arco voltado para a esquerda (1), depois outro a encerra, voltado para a direita (2). Devido à sua irregularidade quanto à forma e ao ductus, em alguns casos, aparece com o corpo aberto e é escrita com apenas um traço em meia circunferência, observada em desenho, ou como um $\langle\mathrm{u}\rangle$, apontada em nomear. 


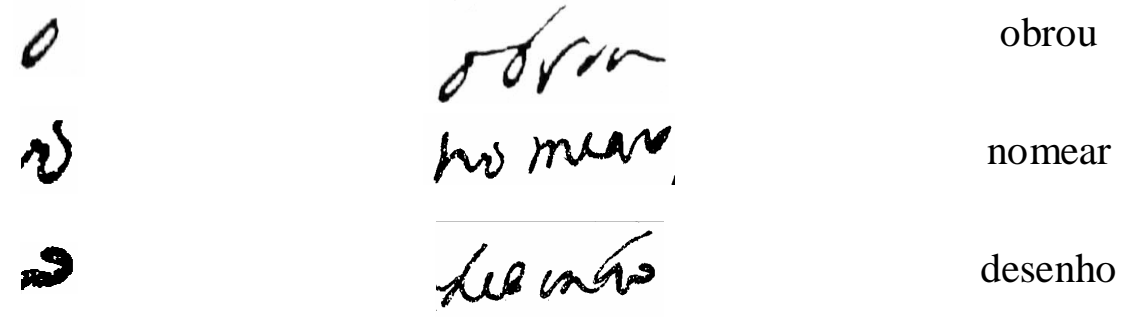

\section{Letra $<\mathrm{u}>$ :}

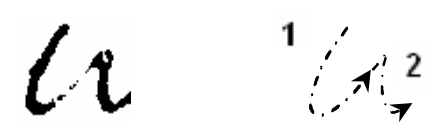

Essa letra é usada tanto com valor de vogal, quanto de consoante, substituindo o $\langle\mathrm{v}\rangle$. Todas as formas possuem traçados semelhantes, formadas em dois tempos e com dois traços. No primeiro tempo, a partir da linha média "b", um traço, levemente encurvado para a esquerda, desce até a base do regramento, onde faz uma curva para a direita e sobe até a altura de onde se iniciou (1) e se encerra, no segundo tempo, voltando a descer como anteriormente (2). Em certos casos, pode ser confundida com a letra $\langle\mathrm{v}\rangle$, pela semelhança de traçado em seu primeiro tempo de formação. Entretanto, seguindo o modelo levantado por Figueiredo (1722) em seu alfabeto, a letra $<u>$ se caracteriza por ser encerrada com mais um traço (2) além do que foi delineado na sua primeira etapa, independente de seu aspecto em $v$ inicial, como pode ser observado em Paulo e obrou.

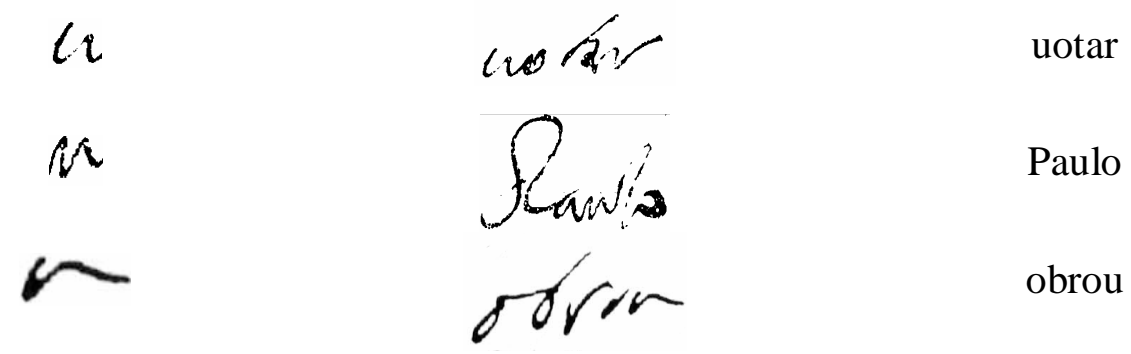




\section{Consoantes}

\section{Letra $<\mathrm{m}>$ :}

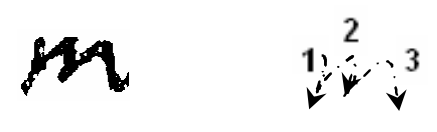

Essa letra é escrita em três tempos, cada qual com o seu traço. O primeiro inicia-se na altura da linha média "b" do regramento e, levemente encurvada para a direita, desce até a linha média "a" (1). No segundo tempo, pela mesma linha do traço anterior, sobe até a sua metade e, inclinadamente para a direita, vai até a linha média "b", onde faz uma curva para a direita e volta a descer à base (2). No terceiro, repete-se o traçado anterior e encerra-se a letra (3).

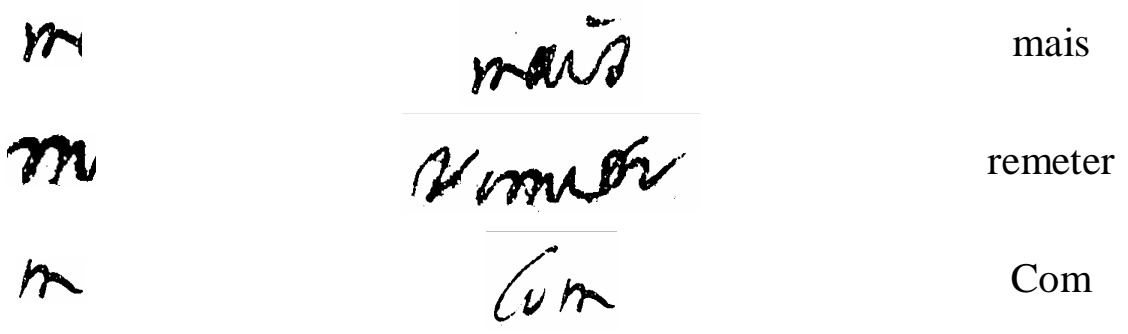

\section{Letra $<\mathbf{n}>$ :}

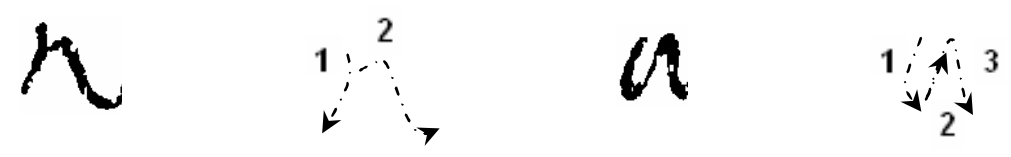

Essa letra possui duas formas, ambas formadas em dois tempos, cada qual com um traço. A primeira é semelhante à levantada por Figueiredo (1722). Inicia-se na linha média 
"b" e, ligeiramente encurvado para a direita, desce até a linha média "a" (1). No segundo tempo, pela mesma linha do traço anterior, sobe até um pouco mais de sua metade e, inclinadamente para a direita, vai até a linha média "b", onde faz uma curva para a direita e volta a descer à base, inclinado e levemente encurvado para a esquerda (2). A segunda forma tem seu início semelhante ao da anterior no primeiro tempo (1), mas diferencia-se na sua continuação. Da linha média "a”, inclinadamente para a direita, sobe até a linha média "b” (2), em seguida, desce, levemente inclinado para a esquerda, até a linha em que se iniciou o primeiro (3).

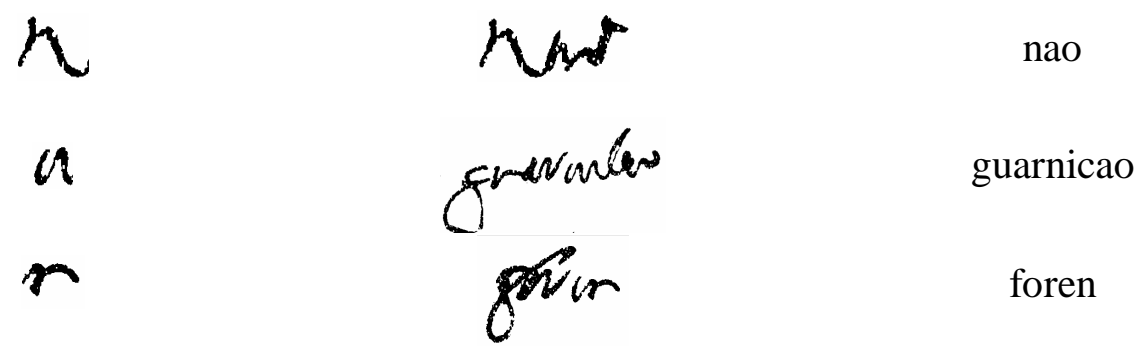

\section{Letra $\langle\mathbf{r}>$ :}
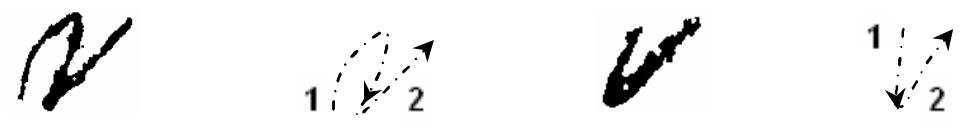

Essa letra é formada em dois tempos, por um traço. Inicia-se na linha média "a" do regramento e sobe, encurvado para a direita, até a linha média "b", faz uma curva e volta a descer (1), de onde sobe, inclinado para a direita, até a altura da linha "b" (2). Às vezes, aparece com seu traçado simplificado, semelhante a um $\langle\mathrm{v}\rangle$, como se observa em tornara. 


\section{6 \\ $6+12$ \\ tornara \\ $N$ \\ acen \\ auer}

\section{Letra $\langle\mathrm{s}>$ :}
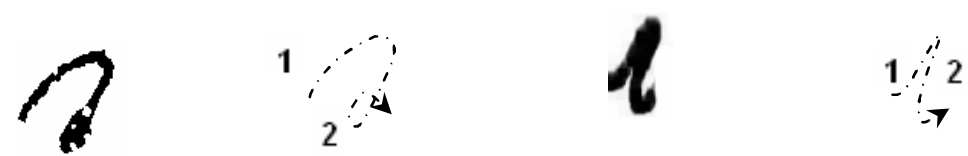

Essa letra não tem bem definida o tamanho de seu módulo, grande e pequeno. A diferença entre um e outro é muito tênue, o que dificulta diferenciar maiúsculas de minúsculas. Para manter padronizadas essas ocorrências, optou-se por marcar todas as formas encontradas no corpus com módulo pequeno. As formas em início de palavra são semelhantes, independente de sua variação modular. Geralmente, inicia-se um pouco acima da linha média "a" e sobe, encurvado para a direita, até um pouco acima da linha média "b", faz uma curva e volta a descer (1) onde se encerra com uma curva fechada voltada para a esquerda até cortar o traçado anterior (2). Pode vir simplificada sem o arco inicial, como em sera. Em meio de palavra, apresenta forma e traçado semelhantes aos das letras $\langle\mathrm{e}\rangle \mathrm{e}\langle\mathrm{i}\rangle$, como pode ser constatado em Escreuasse. No final de palavra, pode vir sem a curva que o encerra, observada em alguas.
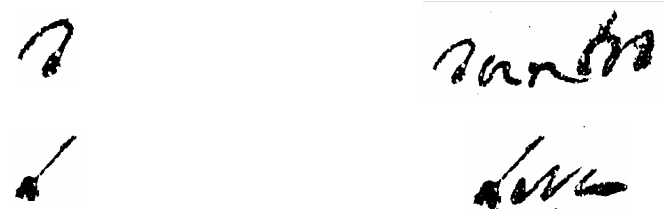

santos

sera 


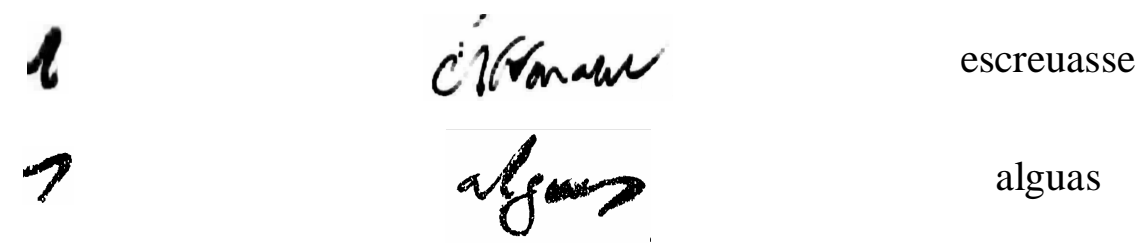

Letra $<x>$ :

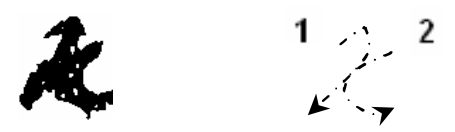

Feita em dois tempos, com dois traços, essa letra se apresenta como a que aparece no alfabeto de Figueiredo (1722). No primeiro tempo, entre as linhas médias, realiza-se um arco voltado para a esquerda (1); no segundo, um outro voltado para a direita (2), unidos pelo meio.

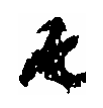

$a^{2}$

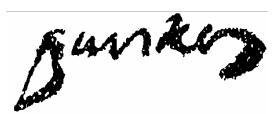

25 queixas

Lisboa

Letras que possuem haste

\section{Letra $\langle\mathbf{b}\rangle$ :}

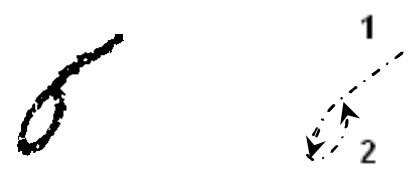


É uma das letras mais uniformes no corpus, o que varia é o nível da inclinação de sua haste. É formada em dois tempos, por dois traços. O primeiro, a partir da linha superior, desce inclinadamente para a direita até a linha média "a" (1), após isso, é encerrada por meio de uma curva voltada para a direita (2).
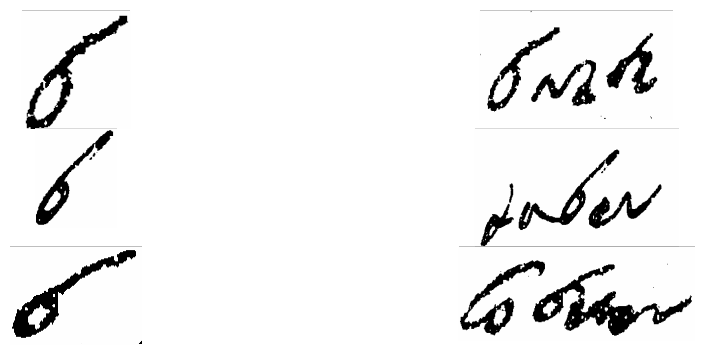

baste

saber

Cobrar

\section{Letra $<\mathrm{d}>$ :}
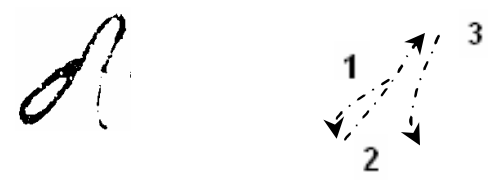

Embora seja de fácil identificação, a forma dessa letra varia bastante, principalmente, no que diz respeito à sua haste. Feita em dois tempos e, geralmente, com dois traços, o primeiro forma a curva de seu corpo (1) e sobe, num segundo tempo, inclinadamente para a direita, até a linha superior (2), podendo ir, em certos casos, ligar-se à letra posterior, num terceiro tempo, com um outro traço (3). Em outros casos, primeiro é feito seu corpo com uma curva, depois, um traço, suavemente encurvado para a esquerda, desce formando a haste, como no $<\mathrm{d}>$ de fazenda.

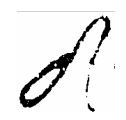




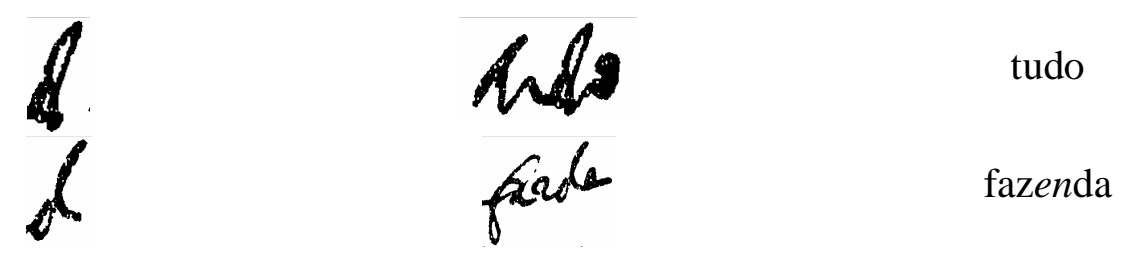

\section{Letra $\langle\mathrm{h}>$ :}

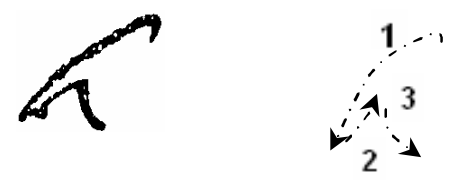

Essa letra é formada em três tempos, por três traços. No primeiro tempo, forma-se a sua haste, com um traço que desce, inclinadamente para a direita, da linha superior até a linha média "a" (1). No segundo, um traço sobe dessa linha, inclinadamente para a direita, até a linha média "b" (2), em seguida, volta a desce, inclinado e levemente encurvado para a esquerda, (3), formando uma espécie de pirâmide. Ao lado da letra <l> aparece com módulo menor, o que dificulta a sua identificação.
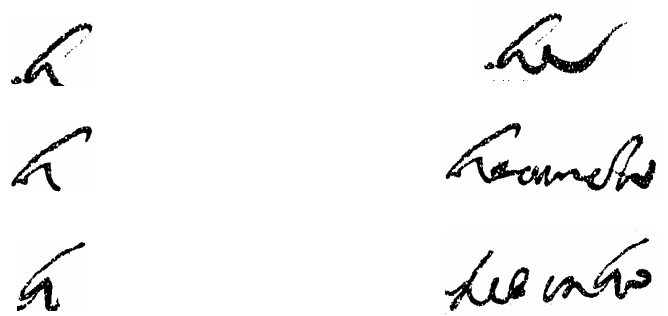

he

hauendo

desenho

\section{Letra $<\mathrm{l}>$ :}
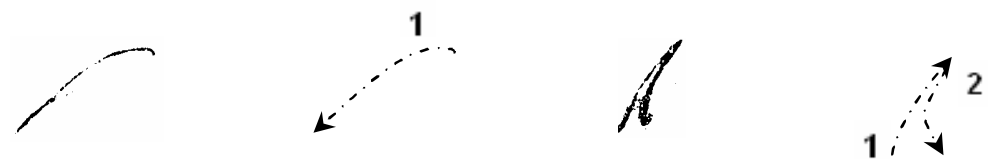
Essa letra é formada num único tempo, com um traço levemente inclinado para a direita (1). Geralmente, em posição medial, é escrita em dois tempos. Iniciada na linha média “a”, por um traço ascendente e inclinado para a direita até a linha superior (1), de onde desce, levemente encurvado para a esquerda (2), como pode ser observado no $<1>$ de defenCauel.

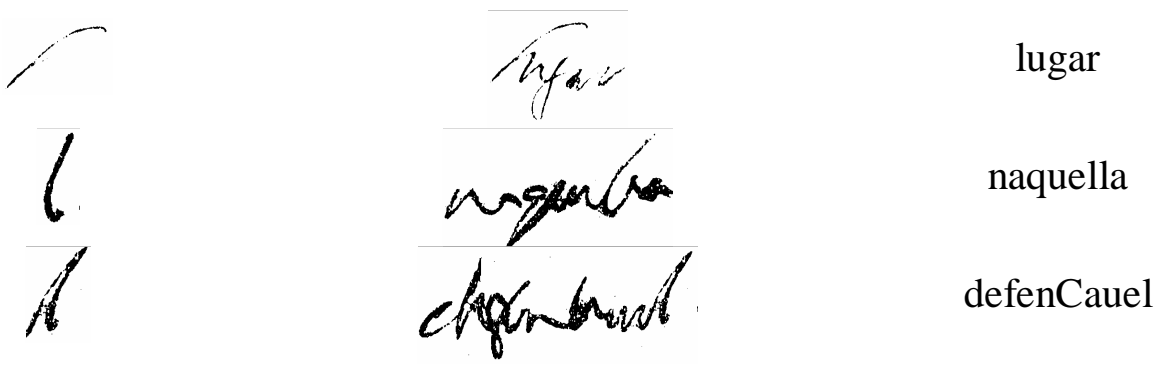

\section{Letra $\langle\mathbf{t}>$ :}

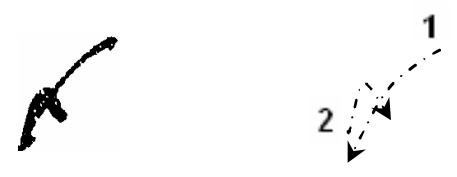

Nem sempre a haste dessa letra chega à linha superior do regramento como se observa no alfabeto modelo, porém, às vezes, a ultrapassa. Feita em três tempos e com dois traços, inicia-se com um traço vertical que desce, inclinadamente para a direita, até a linha base (1) e, depois, sobe, à direita e estreitamente ligado ao primeiro, até a linha média "b" (2), onde encurva-se para a direita e o corta. Em certos casos, o segundo traço sobe pelo anterior, colando-se nele, como pode ser constatado no $<\mathrm{t}>$ de tudo e de planta.
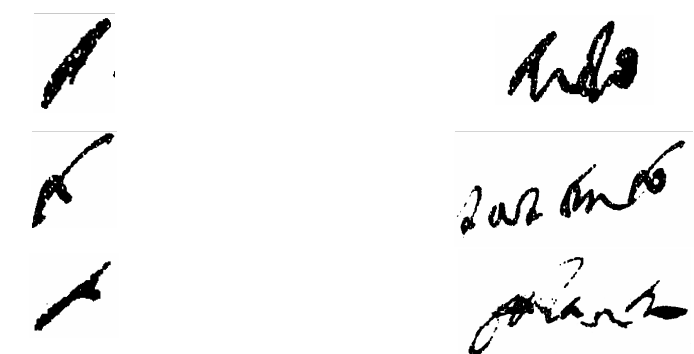
tomar
sustento
planta 


\section{Letras que possuem cauda}

\section{Letra $\langle\mathrm{g}>$ :}
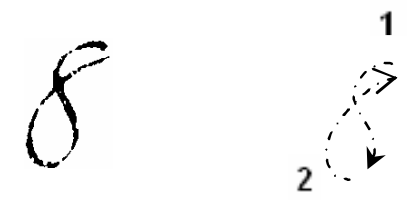

É escrita em dois tempos, com apenas um traço. No primeiro, na altura da linha média "b", realiza-se uma curva voltada para a esquerda e começa a descer, na altura da linha média "a", faz uma curva para a direita e desce até a linha inferior (1). Esse mesmo traço sobe, encurvado para a esquerda, corta o traçado anterior na altura da linha média "a" e encerra a letra antes de chegar à "b" (2).

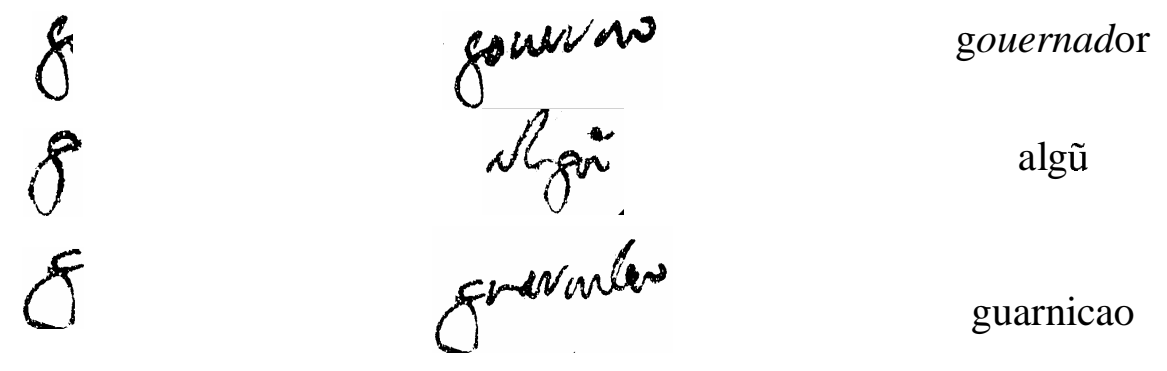

\section{Letra $\langle\mathbf{j}>$ :}
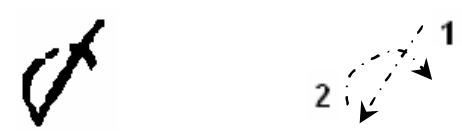

Essa letra é formada em dois tempos, por um único traço. Para facilitar a sua descrição, supõe-se que o $<\mathrm{j}>$ utilizado no corpus ocupasse os esquema do regramento, pois, 
na realidade, essa letra, embora possua haste, apresenta-se a partir da linha média "a" para cima. Num regramento ideal, seria iniciada na altura da linha média "b" e desceria, inclinadamente para a direita, até a linha inferior (1), voltaria a subir, em linha curva para a esquerda, até cortar o traçado anterior na altura da linha média "a" (2).
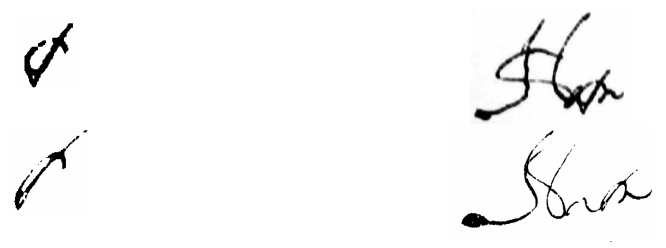

Haja

Haja

\section{Letra $\langle\mathbf{p}>$ :}
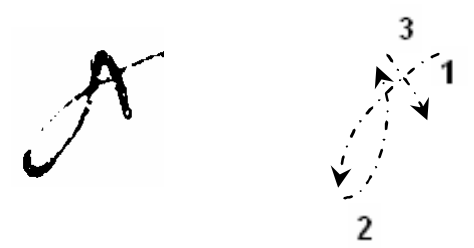

Essa letra é muito parecida com o $\langle\mathrm{f}\rangle$, mostrado mais abaixo. É formada em três tempos, por um traço contínuo. A diferença está em seu traço inicial que, diferente do da outra, não começa na linha superior do regramento, mas na altura da linha média "b" e desce, inclinadamente para a direita, até a linha inferior (1), volta a subir, levemente encurvada para a direita, corta o traçado anterior na altura da linha base e vai até a "b" (2), onde faz uma curva para a direita e volta a descer para encerrar a letra um pouco abaixo da linha média "a".
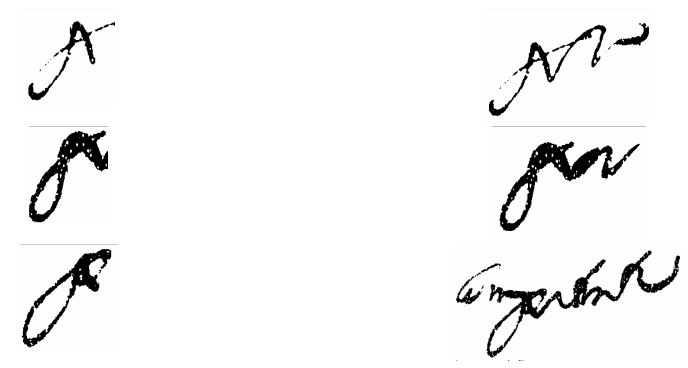

primeiro

por

Competente 


\title{
Letra $<\mathbf{q}>$ :
}

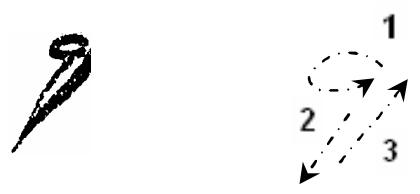

Seu corpo é formado por um círculo (1), de onde sai um traço que desce, levemente inclinado para a direita, até a linha inferior do regramento (2) e, volta a subir (3), ora paralelamente, como em naquella, ora encurvado para a esquerda e para a direita, como em apliquem. Ocorre também de o terceiro traço, ao subir, encurvar-se para a esquerda e depois voltar para a direita, cortando o anterior, como em quanto.
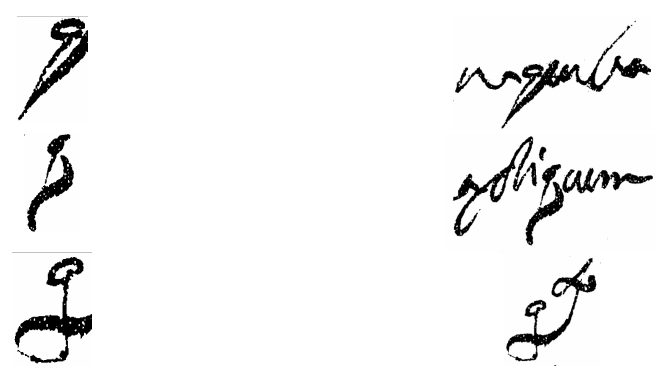

\author{
naquella \\ apliquem \\ quanto
}

\section{Letra que possui haste e cauda}

\section{Letra $\langle$ f $>$ :}
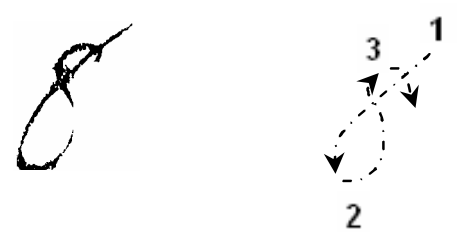

Há quem a confunda com a letra $\langle p>$ em determinados contextos quando sua haste não alcança a linha superior do regramento. É feita em três tempos, também com um único traço contínuo. Da linha superior, desce um traço, inclinadamente para a direita, até a linha inferior (1), volta a subir, encurvado para a direita, corta o traçado anterior na altura da linha base e 
vai até a "b" (2), onde faz uma curva para a direita e volta a descer, cortando novamente o primeiro traço, e encerra a letra (3).
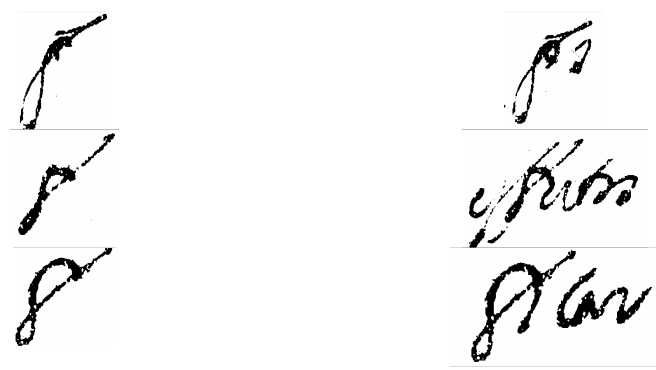

fes

effeitos

ficar

\subsection{Nexos e uniões}

Dependendo da palavra, o levantamento do alfabeto não garante o sucesso de sua leitura. Nexos e uniões entre letras costumam causar deformações, tornando-se necessário analisar as formas assumidas nesses contextos. Não se trata de exemplos literais, pois não há desfiguração total da forma original em todas as palavras, o que ocorre é consequiência do traçado rápido e, aparentemente, descuidado da grafia do escriba. Quase sempre, é a segunda letra que mais sofre variação nessa união. Característica comum da escrita cursiva, essa união aglutinada, muitas vezes, causa alguma deformação que dificulta a sua leitura. Ter isso em vista auxilia na eliminação de pendências no momento da edição, pois se trata de trechos de difícil reconhecimento. Seguem as ocorrências que mais chamaram atenção:

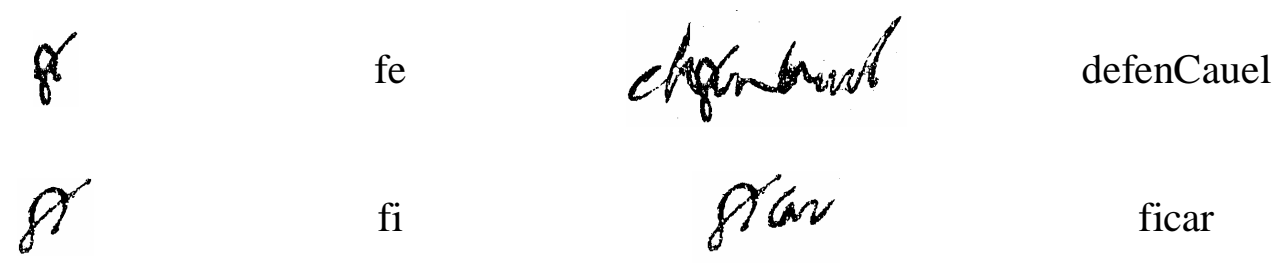


<smiles>C=CC</smiles>

fo<smiles>[Ca]</smiles>

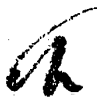

An
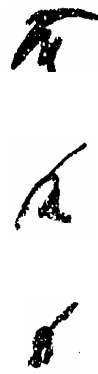

01

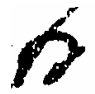

6

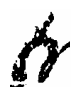

a
11

lh

pe

ta

ta

te

te

to

to

to

tu<smiles>C1=CCCCC1</smiles>

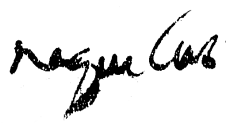

h

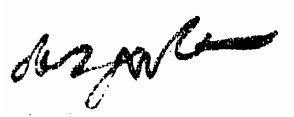

0
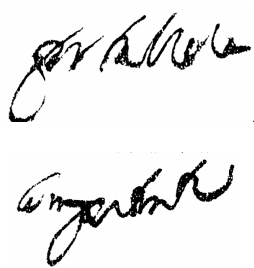

Omagr?

eroto<smiles>[C]1C=[Co]1</smiles>

ando

ads santos

for

naquellas

lhe

despesa

estao

fortallesa

Competente

Pimentel

effeitos

quanto

tudo

\section{Abreviaturas}

Há poucas ocorrências de abreviaturas nos manuscritos com esse tipo de letra. Os únicos casos são por nota tironiana ou taquigráfica, por apócope e por letra sobreposta, em maior número que as anteriores. Trata-se de abreviaturas muito usuais nos documentos 
brasileiros e, portanto, sem dificuldade de desenvolvimento se não fosse pela dificuldade de leitura. A sua identificação é fundamental para a realização da edição de manuscritos.

4.1 Abreviatura por notas tironianas ou taquigráficas:<smiles>C=C</smiles>
$\mathrm{que}$

4.2 Abreviaturas por apócope:



4.3 Abreviaturas por letras sobrepostas:
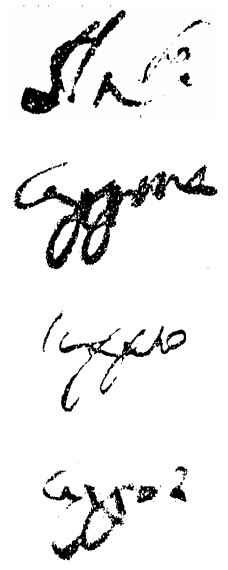

$\operatorname{GN} \omega^{3}$
Antonio

Cappitania

Cappitao

Cappitullos

Carualho 


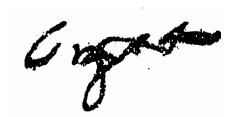

Companhia

$\operatorname{con} 2$
lnoto

Conselho

Consulta

aror

Dezembargador

$2 w^{2}$

Dezembro

faide

fazenda

6

geral

Gol

gouernador

$\sigma^{d a}$

grande

rana

Ianeiro

to

Lisboa

2

Lixboa

and

Manoel

040

$\mathrm{MarCo}$

$n^{6}$

muito

$2 y$

negocio 


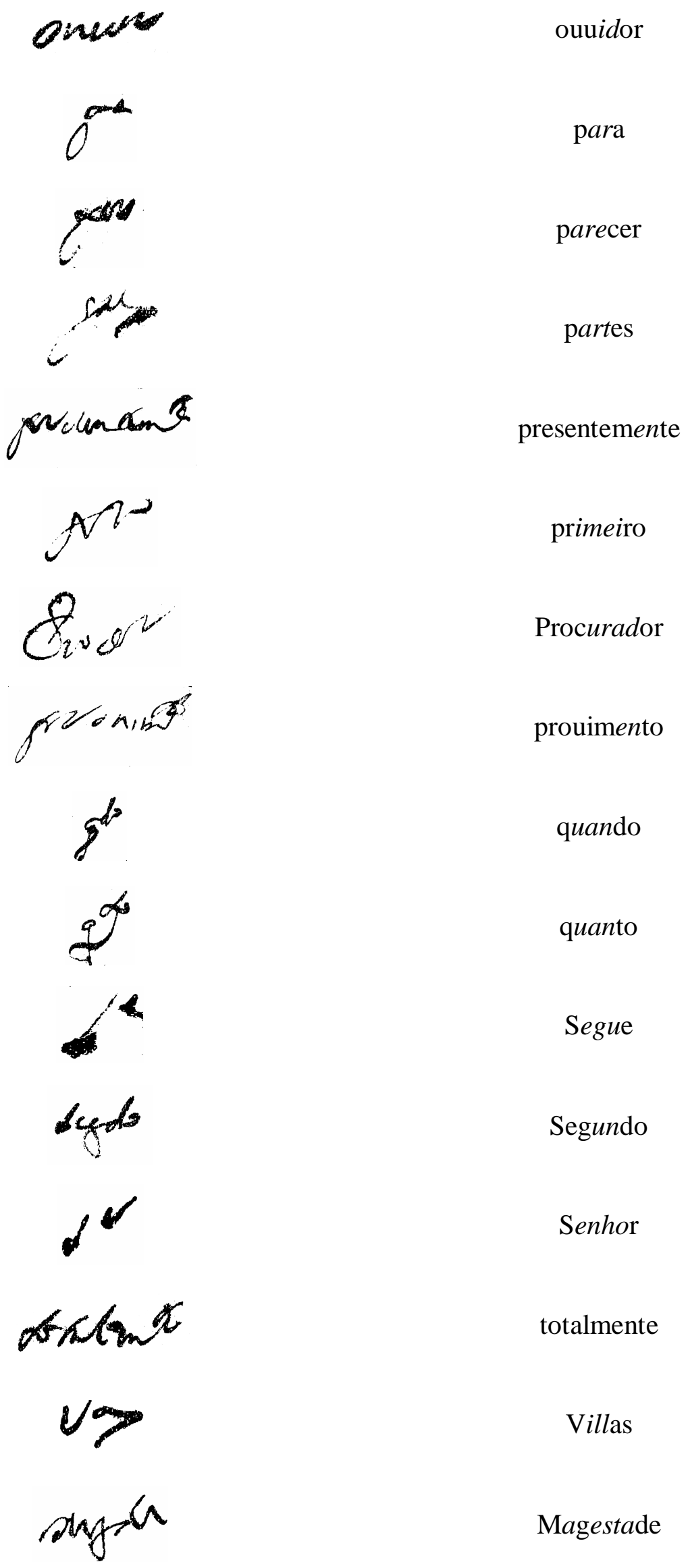




\section{Terceira parte}

\section{A edição semidiplomática dos documentos do Conselho Ultramarino}

\section{Normas para transcrição de documentos manuscritos para a História do Português do Brasil.}

A edição semidiplomática desses documentos foi produzida de acordo com as "Normas para Transcrição de Documentos Manuscritos para a História do Português do Brasil" (CAMBRAIA, CUNHA, MEGALE, 1999:23-6), propostas durante o II Seminário para a História do Português Brasileiro, em Campos do Jordão-SP, no período de 10 a 16 de maio de 1998, pela comissão de pesquisadores composta por Heitor Megale (USP), César Nardelli Cambraia (USP), Gilvan Muller de Oliveira (UFSC), Marcelo Módolo (mestrandoUSP), Permínio Ferreira (UFBa), Sílvio de Almeida Toledo Neto (USP), Tânia Lobo (UFBa) e Valdemir Klamt (UFSC).

1. A transcrição será conservadora.

2. As abreviaturas, alfabéticas ou não, serão desenvolvidas, marcando-se, em itálico, as letras omitidas nas abreviaturas, obedececndo aos seguintes critérios:

a. respeitar, sempre que possível, a grafia do manuscrito, ainda que manifeste idiossincrasias ortográficas do escriba, como no caso da ocorrência "munto", que leva a abreviatura "m. ${ }^{\text {to" }}$ a ser transcrita "munto";

b. no caso de variação no próprio manuscrito ou em coetâneos, a opção será a forma atual ou a mais próxima da atual, como no caso de ocorrências "Deos" e "Deus", que levam a abreviatura "D." a ser transcrita "Deus". 
3. Não será estabelecida fronteira de palavras que venham escritas juntas, nem se introduzirá hífen ou apóstrofo onde não houver.

Exemplos: "epor ser" ; "aellas"; "daPiedade"; "ominino"; "dosertaõ", "mostrandoselhe"; "achandose"; "sesegue".

4. A pontuação original será rigorosamente mantida. No caso de espaço maior intervalar deixado pelo escriba, será marcado [espaço]. Exemplo: "que podem perjudicar [espaço] Osdias passaõ eninguem comparece".

5. A acentuação original será rigorosamente mantida, não se permitindo qualquer alteração. Exemplos: "aRepublica"; docommercio ; "edemarcando tambem lugar" ; "Rey D. Jose" ; oRio Pirahý ; "oexercicio; "que hé munto conveniente".

6. Será respeitado o emprego de maiúsculas e minúsculas como se apresentam no original. No caso de alguma variação física dos sinais gráficos resultar de fatores cursivos, não será considerada relevante. Assim, a comparação do traçado da mesma letra deve propiciar a melhor solução.

7. Eventuais erros do escriba ou do copista serão remetidos para nota de rodapé, onde se deixará registrada a lição por sua respectiva correção. Exemplo: "nota 1. Pirassocunda por Pirassonunga; "nota 2. deligoncia por deligencia"; "nota 3. adverdinto por advertindo".

8. Inserções do escriba ou do copista na entrelinha ou nas margens superior, laterais ou inferior entrarão na edição entre os sinais $<>$, na localização indicada. Exemplo: <fica definido que olugar convencionado é acasa depedro nolargo damatriz>.

9. Supressões feitas pelo escriba ou pelo copista no original serão tachadas. Exemplo: todos ninguem dospresentes assignaron"; "sahiram sahiram aspressas para oadro". No caso de repetição que o escriba ou o copista não suprimiu, passa a ser suprimida pelo editor que a coloca entre colchetes duplos. Exemplo: "fugi[[gi]]ram correndo [[correndo]] emdireçaõ opaço". 
10. Intervenções de terceiros no documento original devem aparecer no final do documento informando-se a localização.

11. Intervenções do editor hão de ser raríssimas, permitindo-se apenas em caso de extrema necessidade, desde que elucidativas a ponto de não deixarem margem a dúvida. Quando ocorrerem, devem vir entre colchetes. Exemplo: "naõ deixe passar neste [registo] de Areas".

12. Letra ou palavra não legível por deterioração justificam intervenção do editor na forma do item anterior, com a indicação entre colchetes: [ilegível].

13. Trecho de maior extensão não legível por deterioração receberá a indicação [corroídas $\pm \underline{5}$ linhas]. Se for o caso de trecho riscado ou inteiramente anulado por borrão ou papel colado em cima, será registrada a informação pertinente entre colchetes e sublinhada.

14. A divisão das linhas do documento original será preservada, ao longo do texto, na edição, pela marca de uma barra vertical: | entre as linhas. A mudança de fólio receberá a marcação com o respectivo número na seqüência de duas barras verticais: || 1v. || 2r. || 2v. $\|3 r .\|^{14}$.

15. Na edição, as linhas serão numeradas de cinco em cinco. Essa numeração será encontrada à margem direita da mancha, à esquerda do leitor. Será feita de maneira contínua por documento.

16. As assinaturas simples ou as rubricas serão sublinhadas. Os sinais públicos serão indicados entre colchetes. Exemplos: assinatura simples: Bernardo Jose de Lorena; sinal público: [Bernardo Jose de Lorena].

\footnotetext{
${ }^{14}$ Como a edição está justalinear às imagens dos manuscritos, não será respeitada a marcação com uma barra vertical para indicar a mudança de linha.
} 
2 A edição semidiplomática dos documentos do Conselho Ultramarino 
Documento 1: despacho escrito em 22 de julho de 1706 em Lisboa, acompanhando uma carta, escrita em 28 de outubro de 1705 em São Paulo.

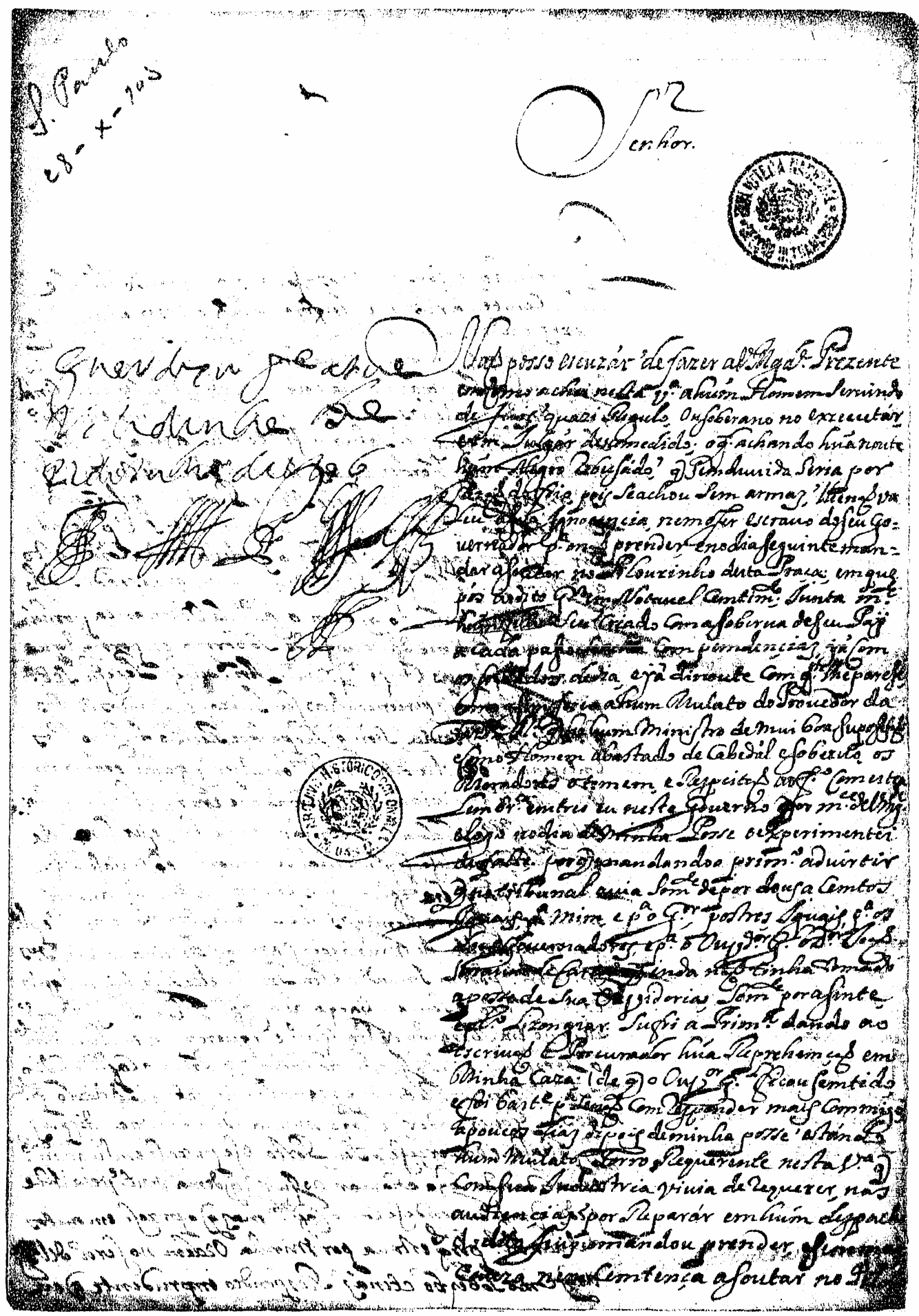


Senhor $^{15}$

$<$ [Guardem] para atua

5 residenCia Lisboa

22 deIunho de $1706^{16}>$

Naõ posso escuzár de fazer aVossaMagestade Prezente

emComo achei nesta Villa a hũm Homem Seruindo

de Juis quazi Regulo, ousoberano no exzecutar

10 eem Iulgár descomedido; o qual achando hũa noute

hũm Negro rebusádo; que Sem duuida Seria por

razaõ do frio, pois Se achou Sem armaz, lhe naõ va

Leu asua Jgnorancia, nem oser escrauo do seu Go=

uernadorepara onaõ prender, e no diaseguinte man=

15 dar asoutar no PiLourinho desta Praça; em que

pos ao dito Gouernador em Notauel Centimento; İunta mente

hũm filho Seu criado Com asoberua deseuPaÿ

a cada passo Seacha Com pemdençiaz ÿá Com

os soldados dedia, eÿá dinoute Com quem lhe parese,

20 como asim seria a hum Mulato do Prouedor da

Fazenda Real que he hum Ministro de mui boa suposisaõ

eComo Homem abastado de Cabedál esoberuo, os

Moradores otemem, e Respeitaõ aofilho Com esta

Lembrança emtrei eu neste Gouerno por merce deVossaMagestade

25 elogo no dia de minha Posse o experimentei

de falta, por que mandando o primeiro aduirtir

que no tribunal auia Somente depor dous a Cemtos

Jguais, para mim, e para o Gouernador, postres, İguais, para os

dous Gouernadorez, e para o OuVidor Geral oDoutorIoaõ

30 Saraiua deCarualho que inda naõ tinha tomado

aposse de Sua ouVidoria, Somente por asinte

epelo Lizongiar, Sufri a Primeira dando ao

escriuaõ e Procurador hũa Reprehençaõ em

Minha caza (de que o ouVidor Geral ficou semtido,

35 e foi bastante para Senaõ Com responder mais Commigo,

a poucos diaz dipois de minha posse estándo

hum mulato Forro Requerente nestaVilla que

comsua Industria Viuia de requerer, nas

audiençias por Reparár em hũm dezpacho

40 do dito Juiz emandou prender, esem mais

couza nem Cemtença asoutar no PiLou

\footnotetext{
${ }^{15} \mathrm{Na}$ margem superior, à esquerda, há a seguinte anotação tardia: São Paulo | 28 - x - 705. Abaixo do vocativo, há uma marca redonda do carimbo da Biblioteca Nacional.

${ }^{16}$ Seguem rubricas.
} 
||1v.

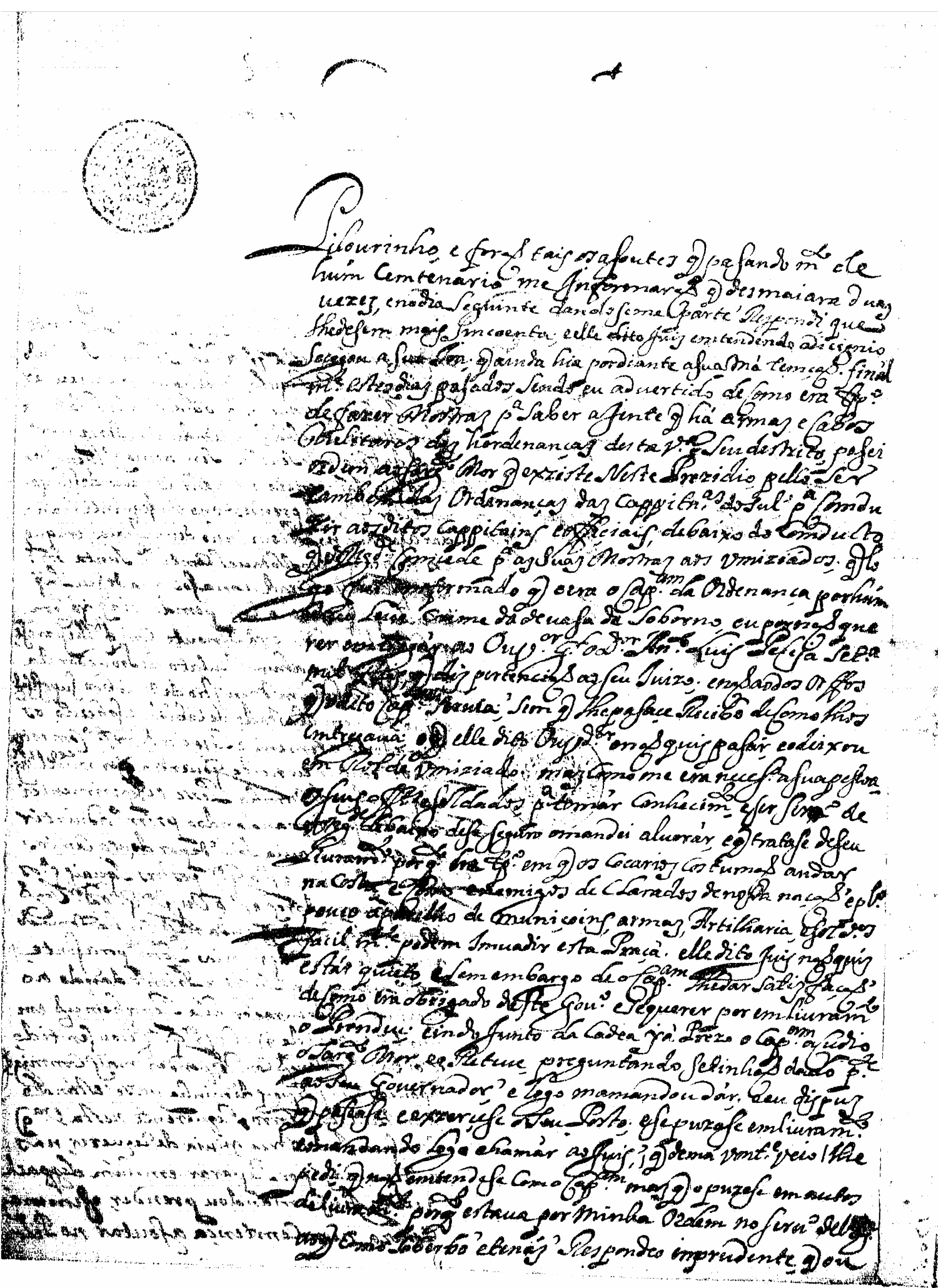




\section{$\|1 \mathrm{v} \cdot\|$}

[[Pilou]]rinho, e foraõ tais os asoutes que pasando muito de hũm Cemtenario me Jnformaraõ que desmaiara duas uezez, e no dia Seguinte dandoseme parte Respondi que lhedesem mais sincoenta; e elle dito Juiz emtendendo adicignis

5 Se cegou a sua İm; que ainda hia por diante asuamá tençaõ. final mente estes diaz pasados, Sendo eu aduertido de Como era [tempo] de fazer Mostraz para Saber asinte que há armaz e Cabos Militares daz hordenançaz desta Villa e Seu destrito, pasei ordem aosargento Mor que exziste Neste Prezidio, pello Ser

10 tambem daz Ordenançaz daz Cappitanias, doSul para Comdu zir aos ditos cappitains e offeciais, debaixo do Comducto que VossaMagestade Comcede para as Suas Mostraz aos vmiziádos, quelo go fui imformado que o era o Capitam da Ordenança por hũm [ilegível] Leue crime da deuasa de Soborno, eu por naõ que

15 rer em lugar ao OuVidor Geral o Doutor Antonio Luis Peleja Serra mil Reis, que diz pertençiaõ ao seu Iuizo; enaõao dos [os] ffilhos que o dito Cappitam Seruia; Sem que lhe pasaçe Recibo deComo lhos emtregaua; o que elle dito OuVidor onaõ quis pasar, e o deixou em Rol do vmiziado, maz Como me era necessariaasuapessoa

20 os seus officiais e soldados, para tomar Conhecimento, e ser ser[uiç]o de VossaMagestade debaixo dese seguro omandei aluorar, e que tratase deseu Liuramento por quanto era [tempo] em que os Cocarioz Costumaõ andar na Costa e Como enemigos deCLarados de nossa naçaõ e pelo pouco aparelho de muniçoins, armaz, Artilharia, esoldados

25 facilmente podem Imuadir esta Praça. elle dito Juis naõ quiz estár quieto, eSem embargo de oCappitam lhedar satizfaçaõ deComo era obrigado deste Gouerno e Se querer por em Liuramento o Prendeu; e indo Junto da Cadea ÿá Prezo o Cappitam aCudio oSargento Mor eo Reteue, preguntando setinhaõ dado parte

30 aoSeu Gouernador; e Logo momandou dár; eeu dispuz que passase e exzerçese oSeu Posto; e se puzese emliuramento emandando Logo chamár ao Juis; (que demá vontade Veio) lhe pedi, que naõ emtendese Como Cappitam maz que o puzese em autos deliuramento por quanto estauapor minha ordem no seruiço deVossa[Magestade] ao que Emo Soberdo etenáz Respondeo inprudente, que ou 


\section{||2r. $\|$}
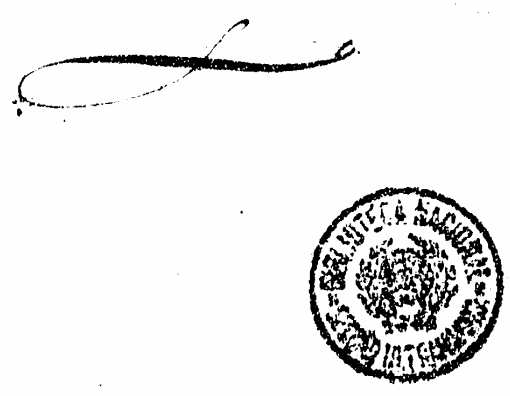

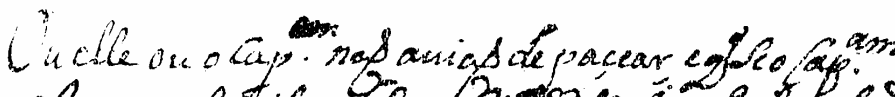

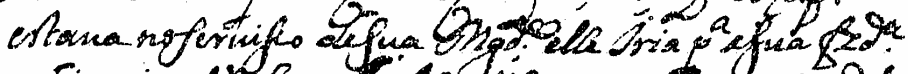

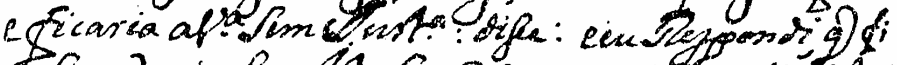

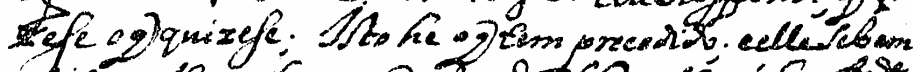

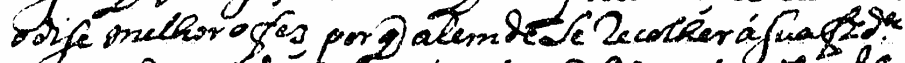

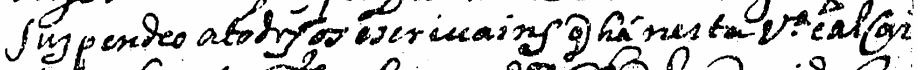

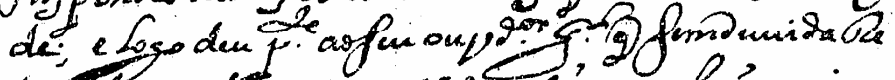

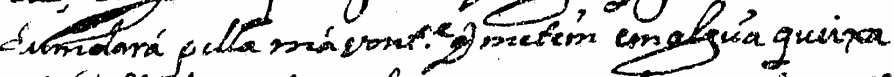

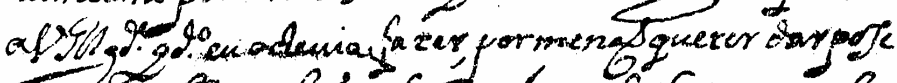

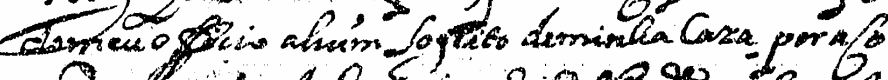

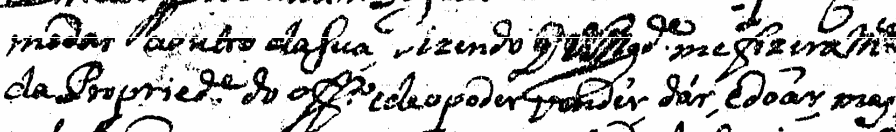

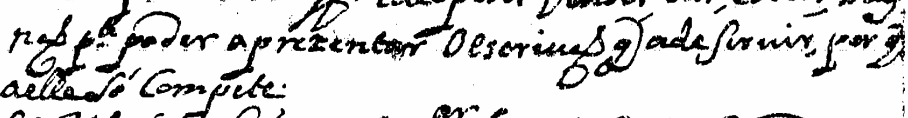

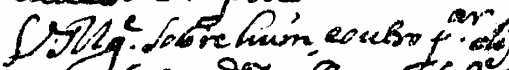

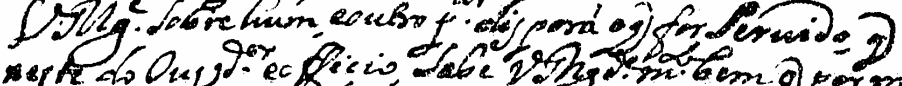

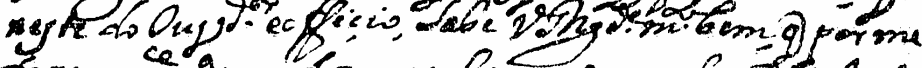

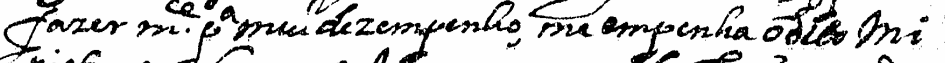

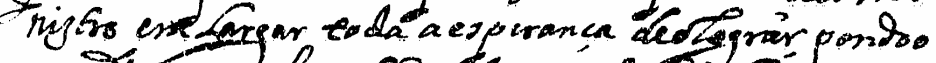

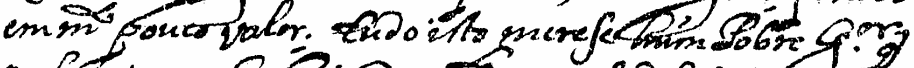

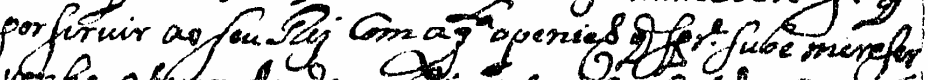

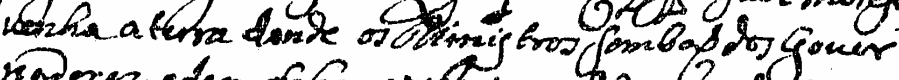

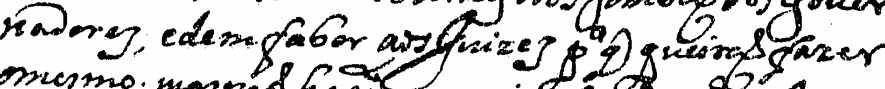

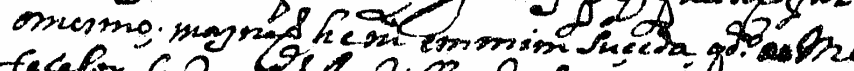

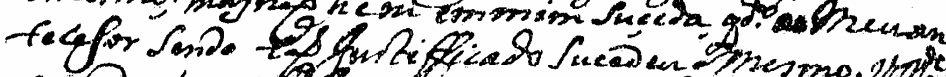
mandará aotalefin.

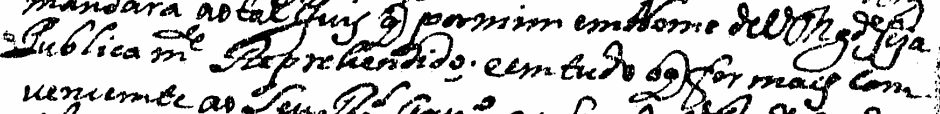

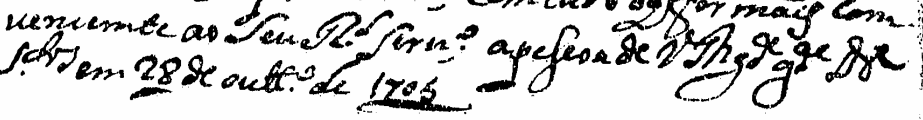
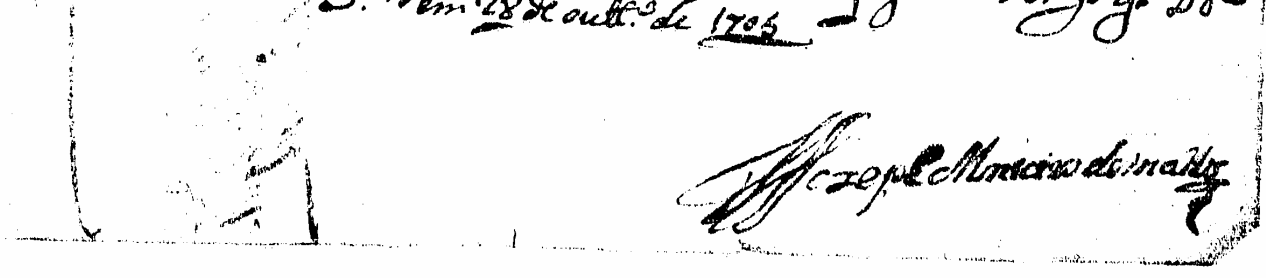
$\|2 \mathrm{r}$.

[[Ou]] elle ou o Cappitam naõ auiaõ de paçear, e que Se o Cappitam ${ }^{17}$

estaua noseruisso desua Magestade elle İria para asua fazenda

e ficaria aVilla Sem İustiça: disse: e eu Respondi, que fi

zese o que quizese; İsto he o que tem precedido; eelleSebem

5 o dise melhor o fez, por que alem de Se recolher á suafazenda

suzpendeo atodoz os escriuains que há nesta Villa e alCay

de; e Logo deu parte aoseu ouVidor Geral que sem duuida Re

dumdará pella má vontade que metém em algũa queixa

aVossaMagestade quando eu o deuia fazer, por menaõ querer dar pose

10 do meu officio ahũm Sogeito de minha caza, por aCo

modar aoutro dasua, [d]izendo que VossaMagestade me fizera Merce

da Propriedade do officio e deo poder vendér dár, e doár, maz ${ }^{18}$

naõ para poder aprezentar o escriuaõ que ade seruir, por que

aelleSó compete;

15 VossaMagestade Sobre hũm, eoutro particular disporá o que for Seruido, que neste do OuVidor e offiçio, Sabe VossaMagestade muitobem, que por me fazer merce para meu dezempenho, me empenha o dito mi niztro em Largar toda a esperança deoLograr, pondo o em muito pouco valor; tudo esto merese hũm Pobre Gouvernador que

20 por seruir ao seu Rej com aquella openiaõ que sempre sube mereser venha a terra donde os Ministros sombaõ dos Gouer nadorez, e dem fabor aos Juizez para que queiraõ fazer omesmo; maz naõ he muito em mim Suçeda, quando ao meuan tecesor Sendo taõ Justifficado Sucedeu omesmo VossaMagestade mandará ao tal Juis que por mim em Nome de VossaMagestadeseja

Publicamente Reprehendido; eem tudo oque for mais com ueniente ao Seu Real Seruiço; apessoa de VossaMagestade guarde Deos Sanctos em $\underline{28}$ de outtubro de $\underline{1705}$

\section{$\underline{\text { Jozeph Monteiro de mattos }}$}

\footnotetext{
${ }^{17}$ Acima da mancha, há uma marca redonda do carimbo da Biblioteca Nacional.

${ }^{18} \mathrm{Na}$ altura dessa linha, na margem esquerda, há uma marca redonda do carimbo do Arquivo Histórico Colonial.
} 
74

Documento 2: despacho escrito em 21 de março de 1710 em Lisboa, acompanhando representação escrita em 27 de agosto de 1709 em São Paulo.

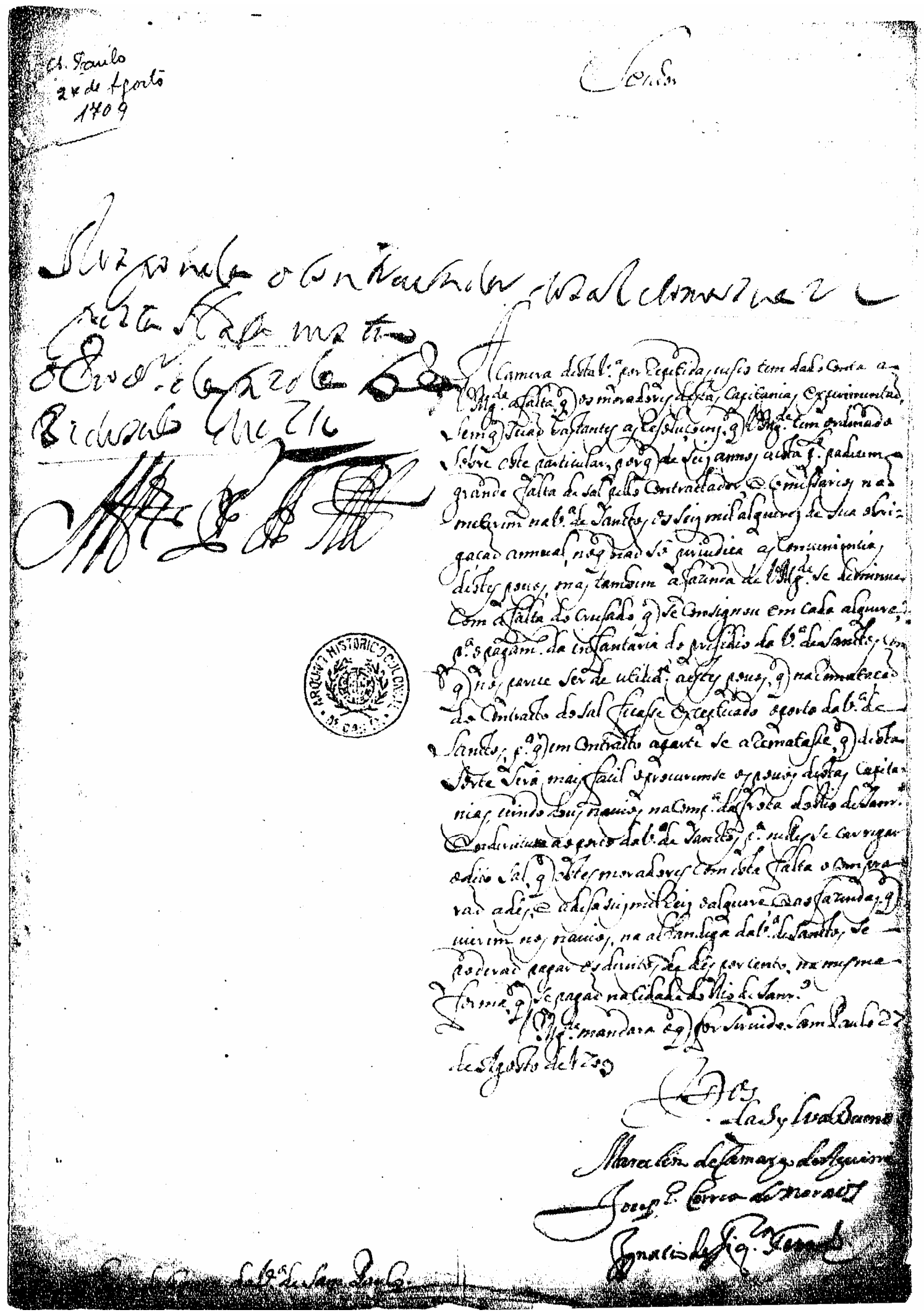




\section{Senhor ${ }^{19}$}

$<$ Responde o Contractador desal eComasua re

posta Haja vista

oProcurador da fazenda Lisboa

531 deMarco de $1710^{20}>$

A Camera desta Villa por repetidas ueses tem dado Conta a

VossaMagestade afalta que os moradores destas Capitanias experimentaõ,

Sem que Seiaõ bastantes as resoluçoens, que VossaMagestade tem ordenado

Sobre este particular, porque de Seis annos a esta parte padecem a

10 grande falta de Sal pello Contractador e Comissarios naõ

meterem na Villa de Sanctos os Seis mil alqueres de sua obri=

gaçaõ annual, noque naõ Sõ periudica as Conueniencias

destes pouos, mas tambem afazenda de VossaMagestade Se deminua

Com a falta do crusado, que se consignou em cada alquere,

15 para o pagamento da infantaria do presidio da Villa deSanctos $\operatorname{com}^{21}$

que nos parece Ser de utilidade aestes pouos, que na remataçaõ

do Contracto do Sal ficasse exceptecado o porto da Villa de

Sanctos, para que em Contracto aparte Se arematasse, que desta

Sorte Serã mais facil oprocuremse os pouos destas Capita-

20 nias, uindo dous nauios na Companhia da frota do Rio deIaneiro

e os dereitos do pouo da Villa de Sanctos para nelles Se carregar

odito Sal que estes moradores com esta falta o compra

raõ adés, e a desaseis mil reis oalquere, eas fazendas, que

uierem nos nauios, na alfandega da Villa de Sanctos Se

25 poderaõ pagar os dereitos de dés por cento, na mesma

forma que Se pagaõ na Cidade do Rio de Ianeiro

VossaMagestade mandara oque for Seruido. Sam Paulo 27

deAgosto de 1709

Domingos daSylvaBueno

Marcelino deCamargo deAguirre

Jozeph Correa deMoraiz

Jnacio desiqueira FerraS

[oficiais da Camara] da Villa de Sam Paulo.

\footnotetext{
19 À esquerda da mancha, há a seguinte anotação tardia: saõ Paulo | 27 de Agosto | 1709

20 Seguem rubricas.

${ }^{21} \mathrm{Na}$ altura dessa linha, na margem esquerda, há uma marca redonda do carimbo do Arquivo Histórico Colonial.
} 
76

Documento 3: minuta de consulta datada de 31 de março de 1710, escrita em Lisboa

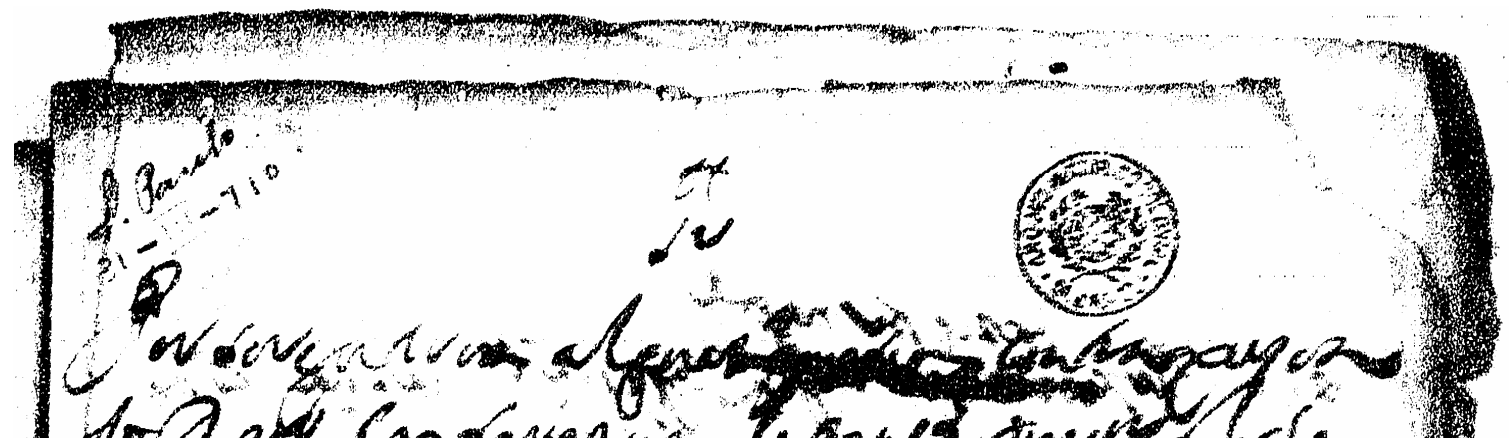

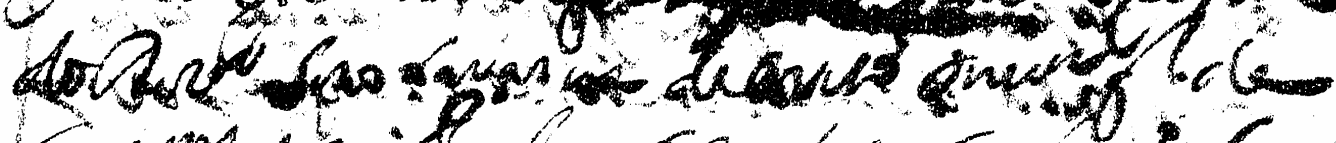

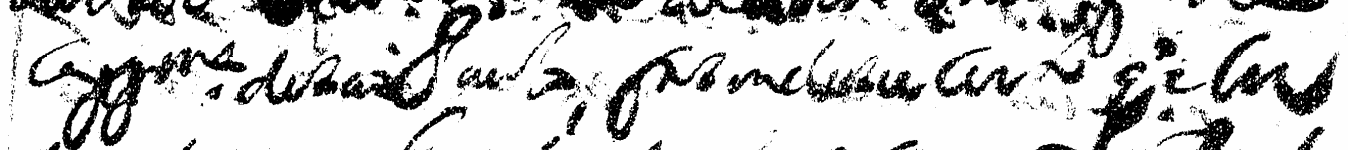

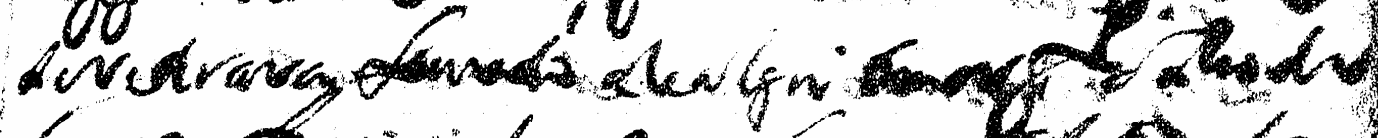

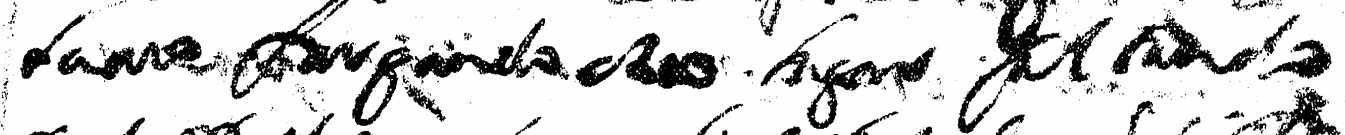

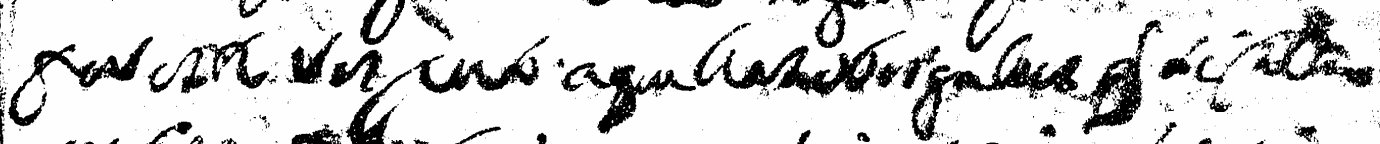

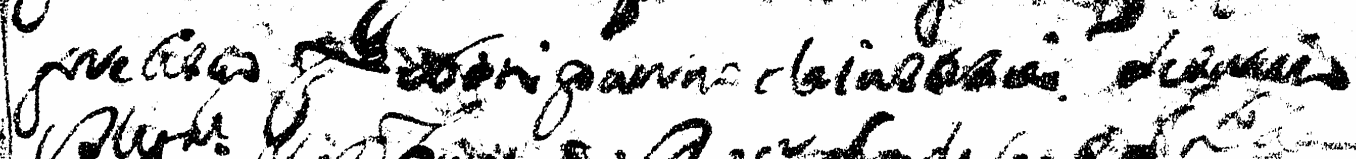

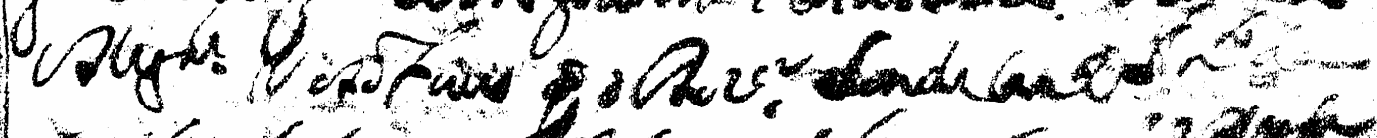

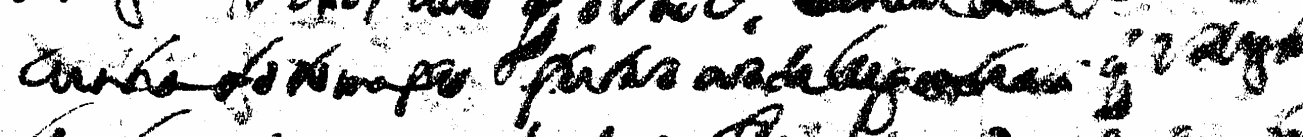

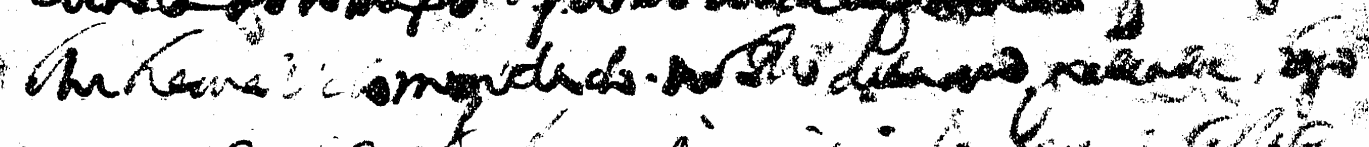

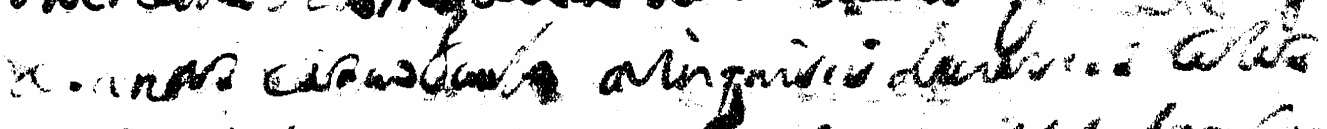

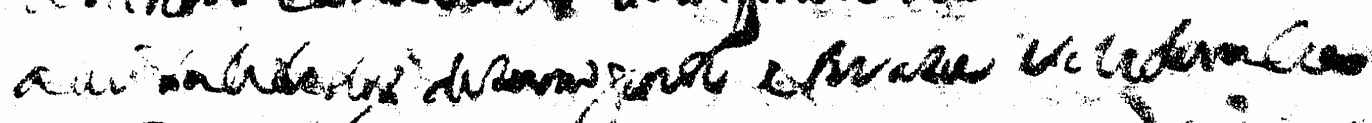

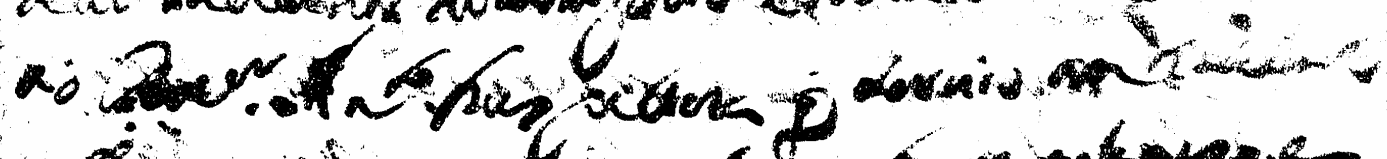

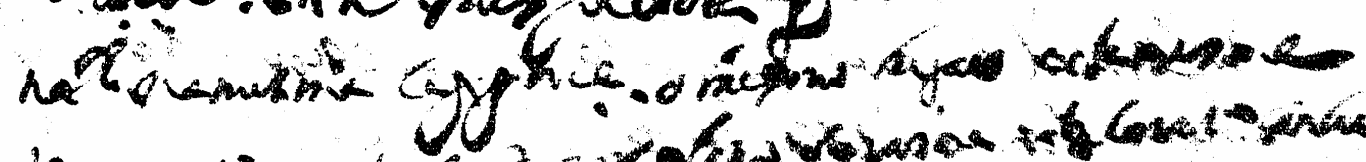

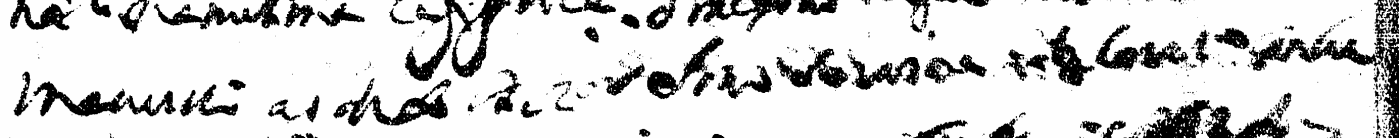

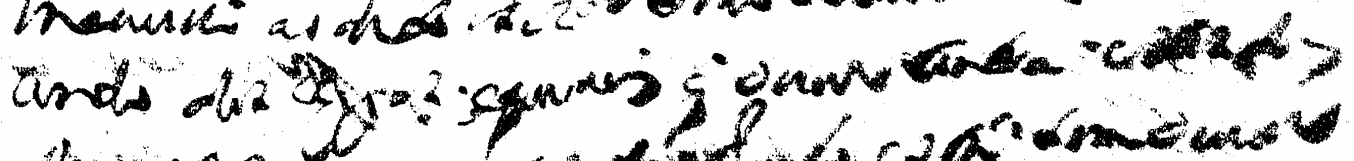

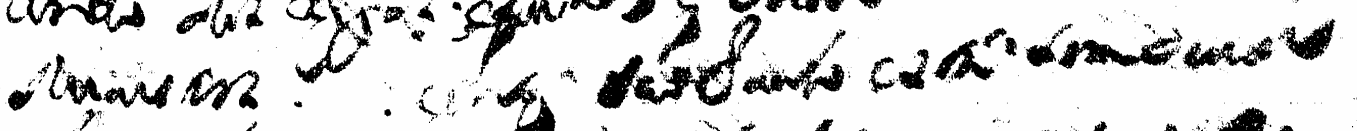

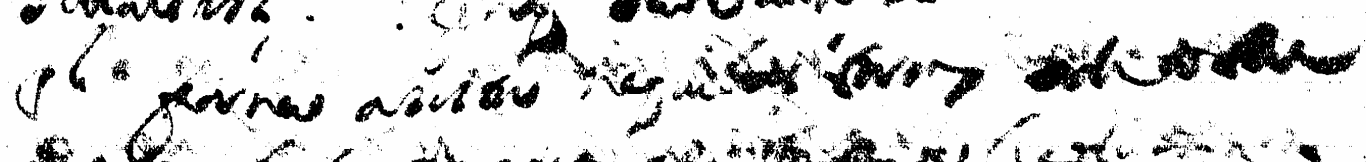

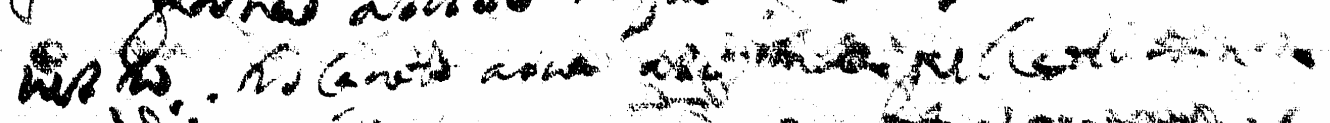

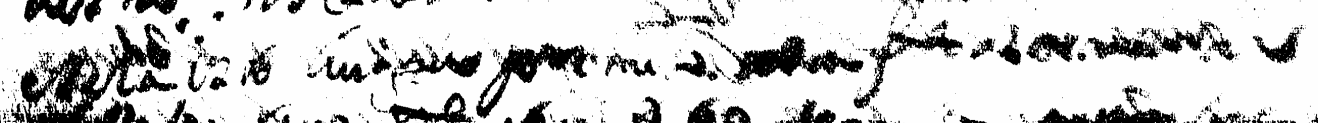

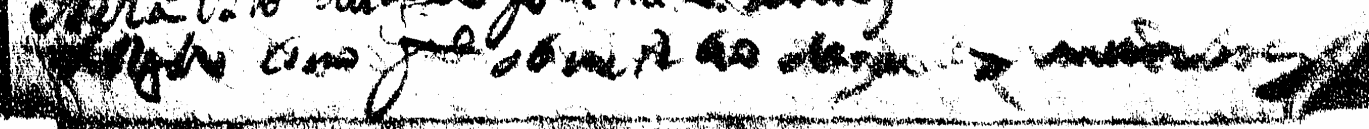


senhor

Por serepetirem alguas [queixas] Contraa[pesoa] ${ }^{22}$

doDezembargador Ioao saraiua de Carualho ouuidor geral da

Cappitania desao Paulo fasendosse Certo que elle

5 seretirara Leuado de algũ [temor] para oRio de

Ianeiro Largando oseo Lugar faltando

por este respeito aquellas obrigaCoes que sefa[Cao]

preCisao para o bon gouerno da iustisa seseruio

VossaMagestade resoLuer que o Dezembargador sindicanteAntonio da

10 Cunha soto ma[y]or feitas as dilligenCias que VossaMagestade

lhe hauia reConmendado noRio deianeiro pa[ssasse] Logo

$\mathrm{a}$ [s]antos easaoPaulo ainquirir de[uarios] Cazos

a[lli] suCedidos desumo porte etirasse residenCia

ao Dezembargador Antonio Luis pelleia que seruio ante[riormente]

15 [ilegível] namesma Cappitania o mesmo Lugar edamesma maneira ao dito Dezembargador Ioao saraiua de Carualho Conhe cendo dos [Cappitulos] equaes que ouue Contra estes do[i]s Ministros e [por] que sao Paulo esta semouuidor geral por nao asistir naquellas terras oditoMi

20 nistro troCando asua a[ssistenCia] pella de [santos] $\mathrm{e}$ [seia] isto [hugrande] preiuiso [asin] para o[seruisso] de VossaMagestade Como para o benefi Cio daquelles [moradores]

\footnotetext{
${ }^{22}$ Na margem superior, à esquerda, há a seguinte anotação tardia: São Paulo | 31 - III - 710. À direita, há uma marca redonda do carimbo do Arquivo Histórico Colonial.
} 
$\|\mathbf{1 v} \cdot\|$

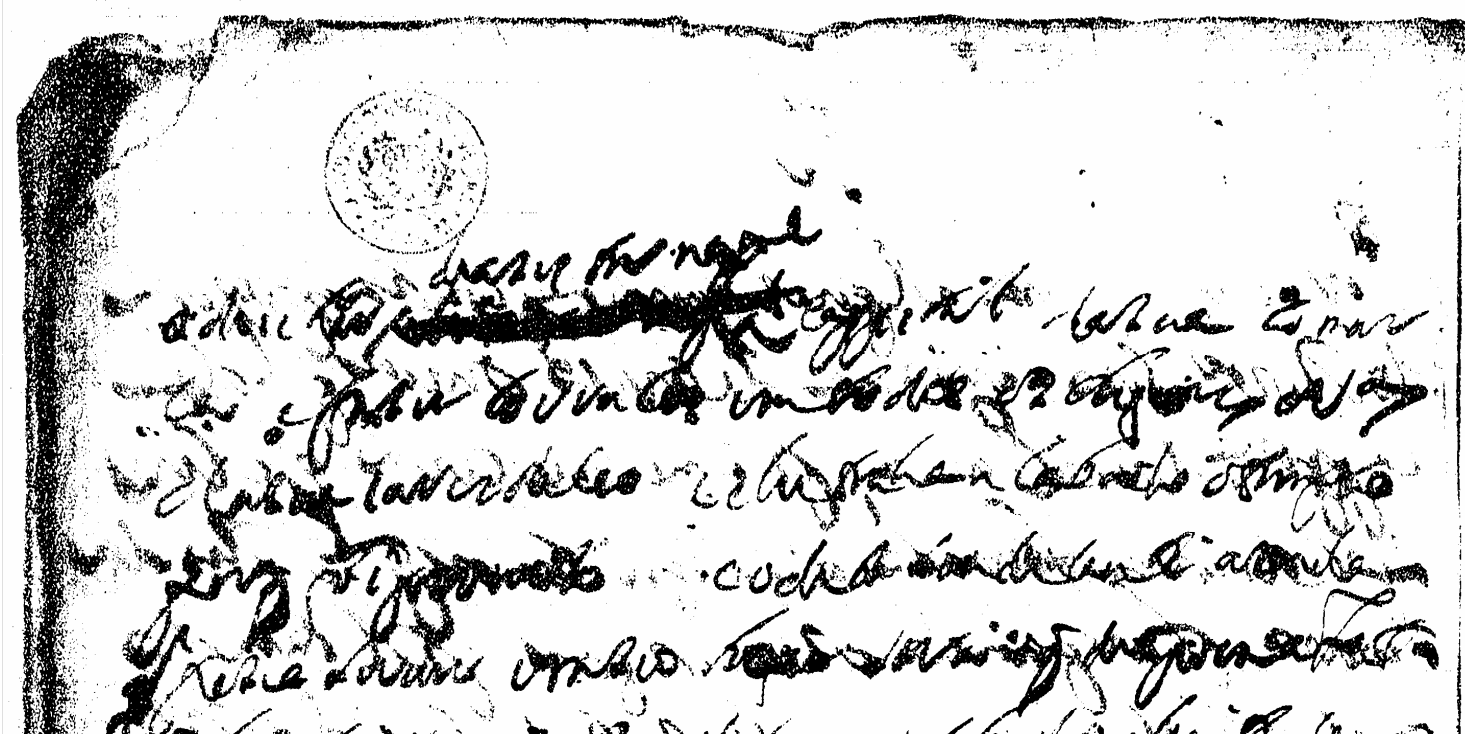

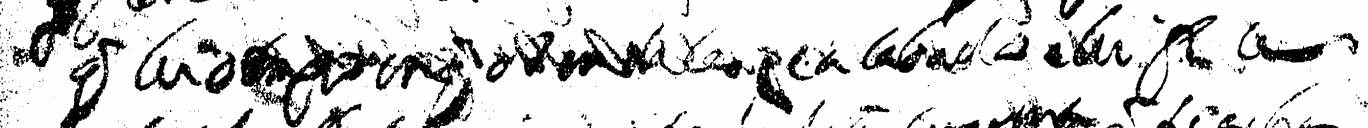

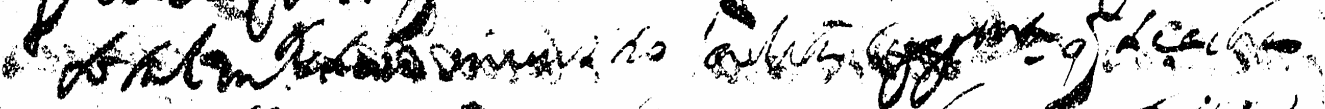

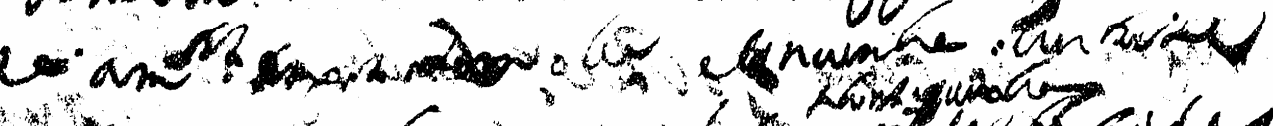

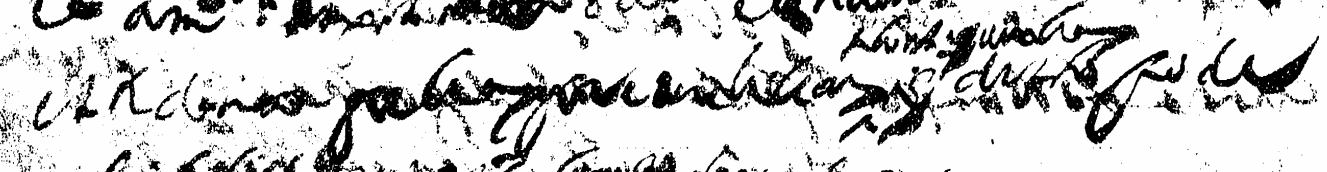

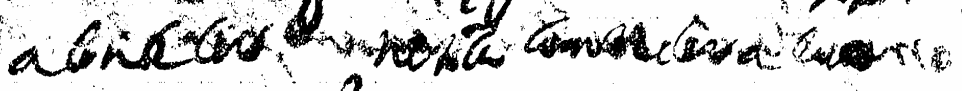

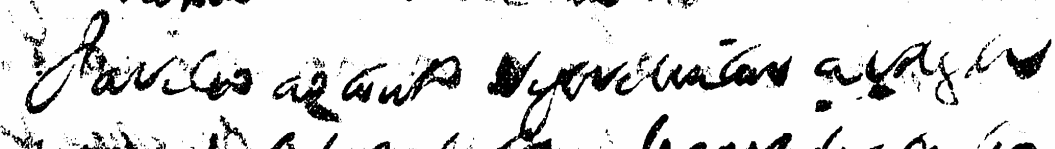

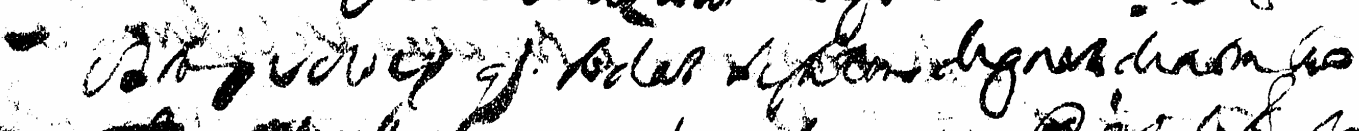

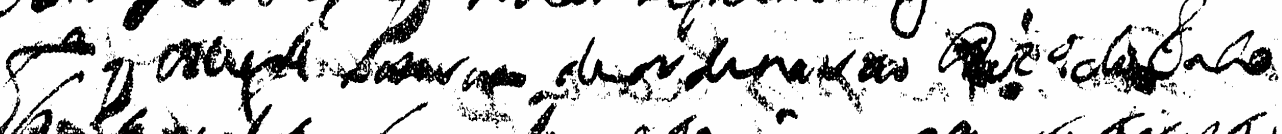

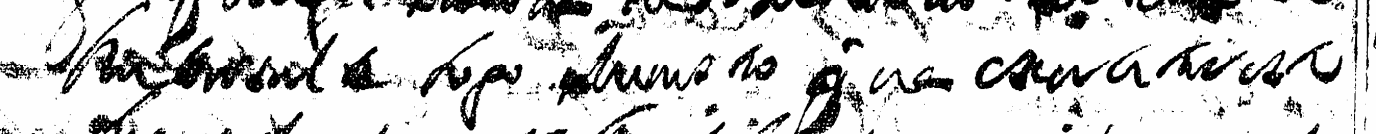

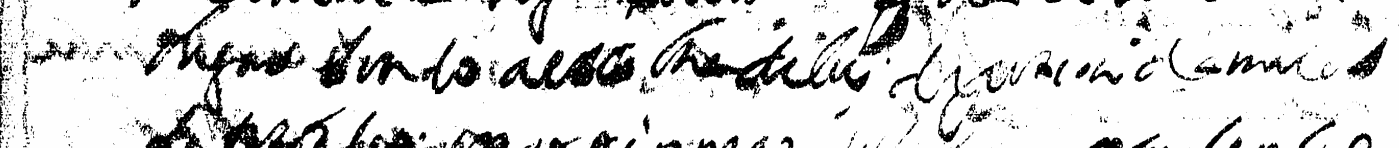

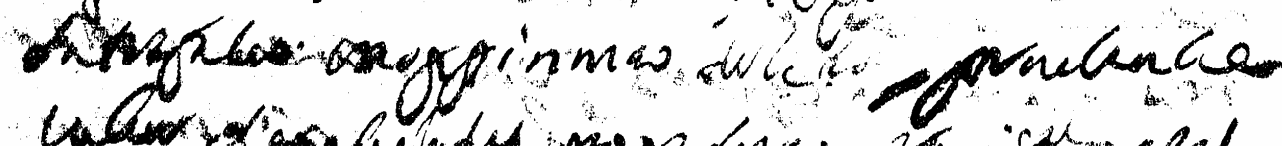

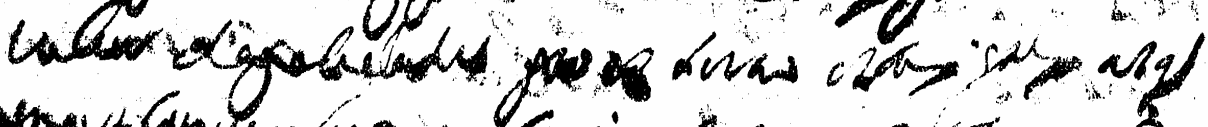

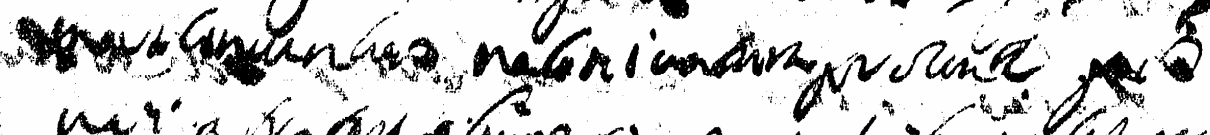

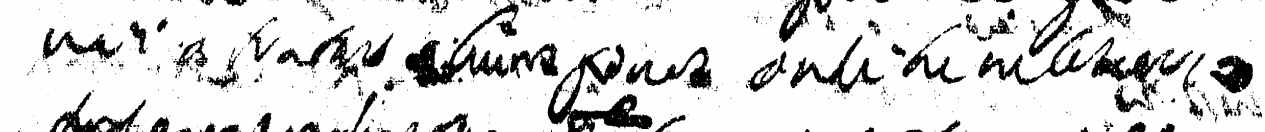

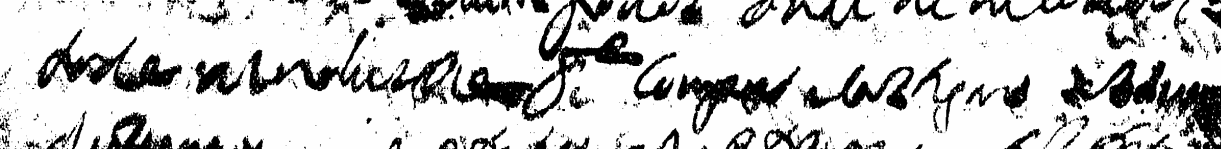

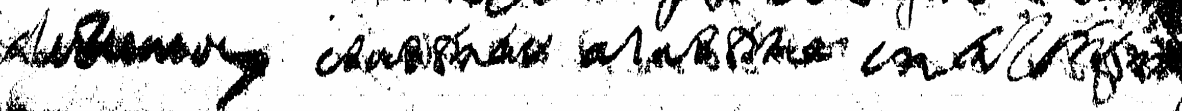




$$
\text { \|1v. }
$$

o deichar <deasistir naparte $>{ }^{23}$ Cappital dasua Comar ${ }^{24}$

Ca efazer CorreCao emtodos os Lugares eVillas

dasua iurisdiCao e elle tenha aCabado otempo

porque foi [prouido] e o dito sindiCante ainda

5 que pos[s]a seruir emseo Lu[gar] sera o que dispoenaLe[y]

que he o tempo enque osindiCa e aCabado elle fiCa

totalmente [sem] ministro adita Cappitania que seacha

[ia] amuitos [annos] sem elle eConuenha euitarse

este [danno] pellas preiudiCiais <ConsequenCias> que disto pode

10 aConteCer nesta ConsideraCao

PareCeo ao Conselho representar a VossaMagestade

estas rezoes que todas sefasen dignas deatenCao

para que VossaMagestade sesirua deordenar ao Dezembargador do PaCo

lhe Consulte Logo Ministro que ua exercitar este

15 Lugar sendo aescolha delle depessoa dama[ior]

satisfaCao enoppinniao de[letras] [e] prudenCia

uallor eCapaCidade pois serao estas partes as que

mais Conuenhao naConiuntura prezente pois

$\mathrm{ua}[\mathrm{y}]$ a tratar a huns pouos onde he neCessario

20 toda aindustria para Compor eCastigar assuas

dezu[niois] esustentar aiustisa entalforma

\footnotetext{
${ }^{23}$ Abaixo dessa inserção, há um trecho de tamanha semelhante, mas muito borrado e de difícil leitura.

${ }^{24}$ Acima dessa linha, há uma marca redonda do carimbo do Arquivo Histórico Colonial.
} 
||2r.||

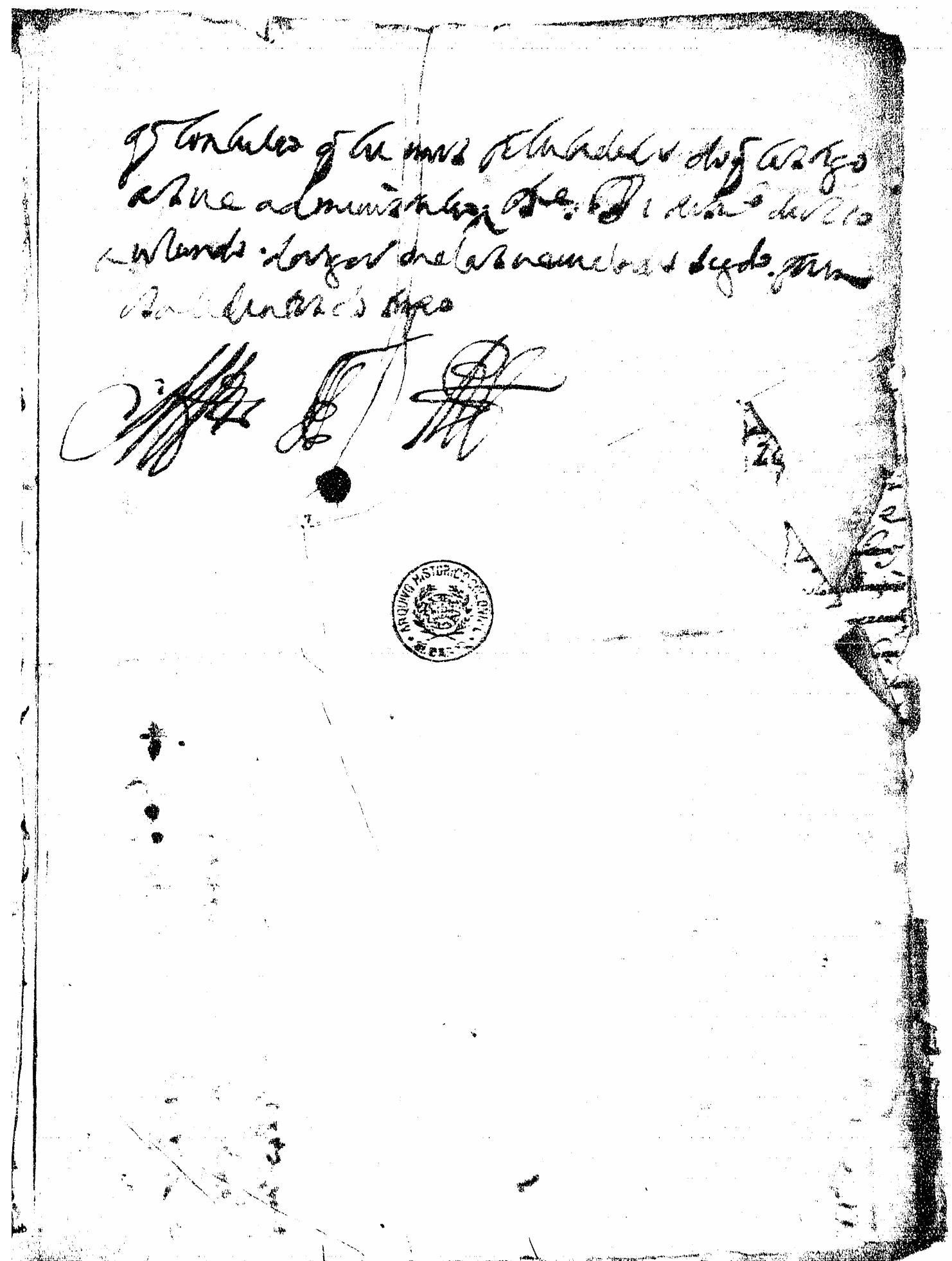

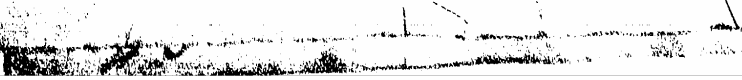


||2r. $\|$

queConheCao que he [mais] fellicidade do que Castigo

asua administraCao Lisboa 31 demarCo de1710

[uzando] dorigor [ou]desuauidade segundo foren

osaCidentes do tempo ${ }^{25}$

${ }^{25}$ Seguem rubricas. Abaixo delas, há uma marca redonda do carimbo do Arquivo Histórico Colonial. 
||3r.||

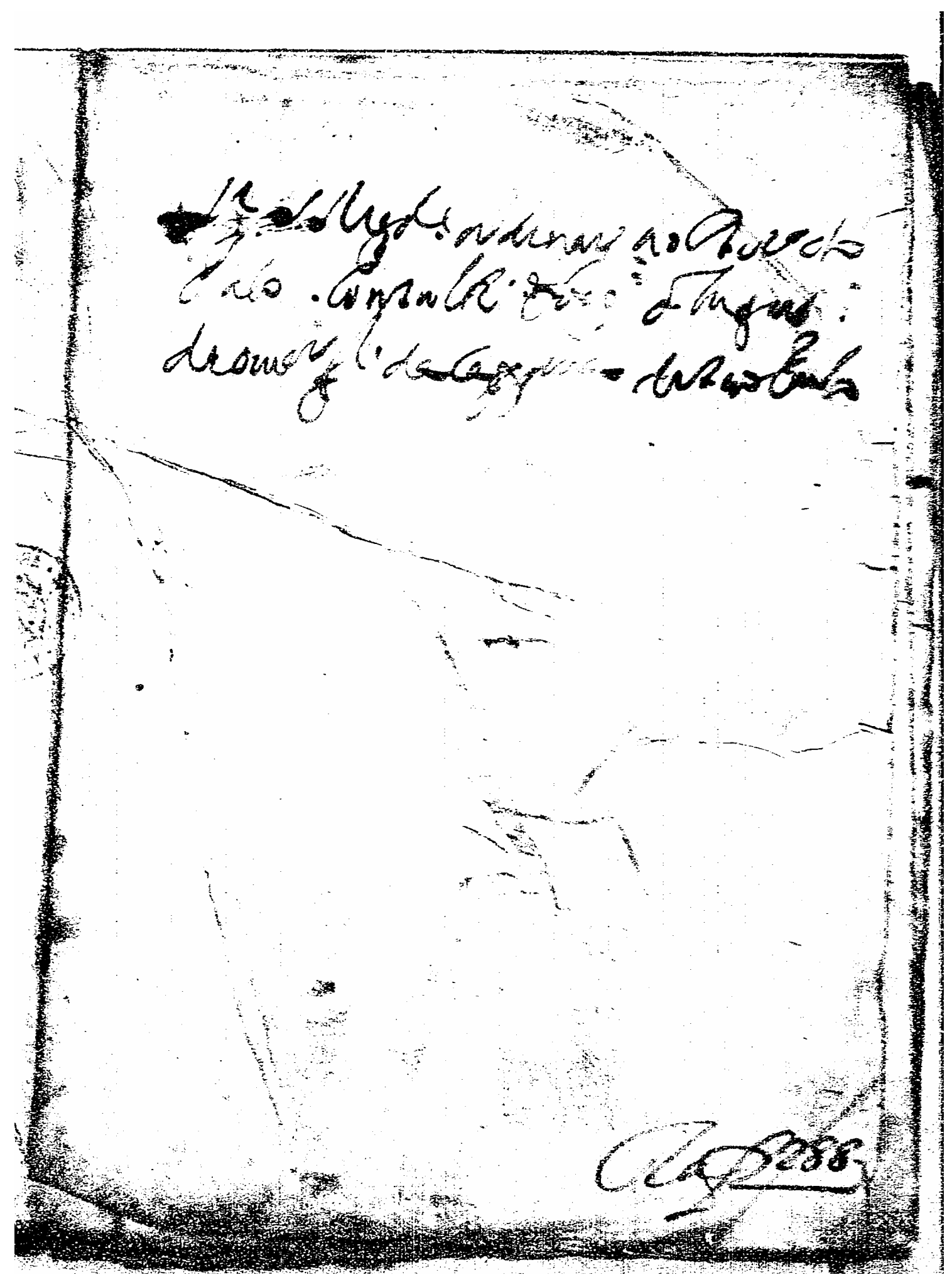


$\|3 r$.

segue sua Magestade ordenar ao Dezembargador do

Paço Consulte [logo] oLugar

de ouuidor geral daCappitania desaoPaulo

Registrada afolhas $\underline{288}$ 
Documento 4: minuta de parecer datada de primeiro de abril de 1710, escrita em Lisboa ${ }^{26}$.

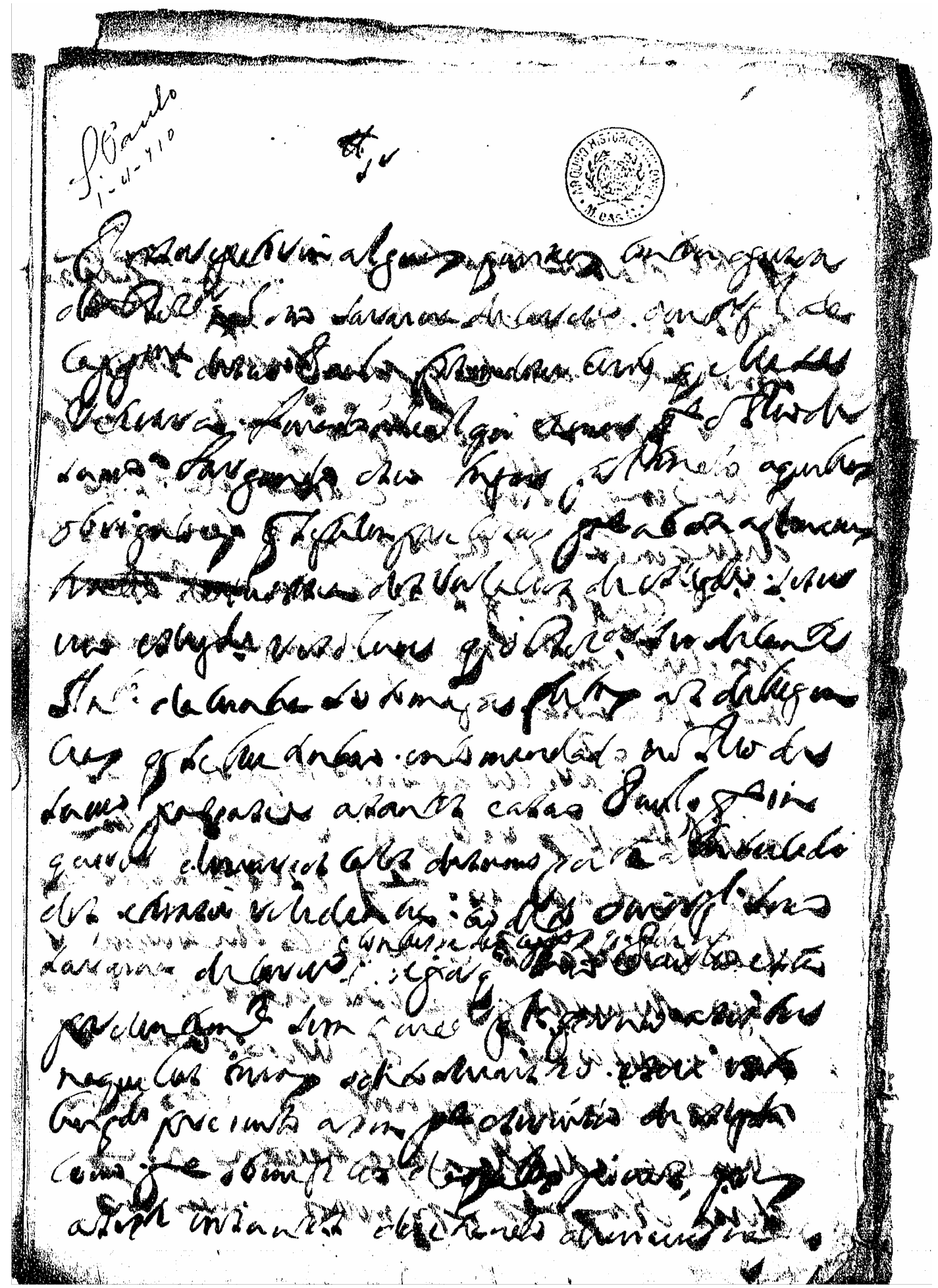

\footnotetext{
${ }^{26}$ Apesar da datação posterior à do documento anterior, ambos fazem referência ao mesmo assunto. Trata-se de duas versões da mesma minuta de consulta.
} 
Porserepetiren alguas queixas Contra apesoa ${ }^{27}$

doDezembargador Ioao saraiua de Carualho ouuidor geral da

Cappitania desao Paulo fasendosse Certo que elle se

retirara Leuado de algu [temor] para oRiode

5 Ianeiro Largando oseo Lugar faltando aquellas

obrigaCoes quesefazen pre Cisas para a [boa] [ilegível]

Æudo [das] [ilegível] dos VaCallos de VossaMagestade seser

uio VossaMagestade resoluer que o Dezembargador sindicante

Antonio da Cunha so to ma[y]or feitas as dilligen

10 Cias quese lhe tinhao enConmendado noRio de

Ianeiro pa[ssasse] asantos easao Paulo para in

querir deuarios Cazos desumo porte [ali] suCedi

dos etirasse residenCia ao dito ouuidorgeral Ioao

saraiua deCarualho <e Conhessa de Cappitulos que [se de no]> e por que sao Paulo esta

15 presentemente sem [ouuidor] geral por nao asistir

naquellas terras o dito Ministro e[seia] isto

[hugrande] preiuiso asin para oseruisso de VossaMagestade

Como para o benefi Cio daquelles pouos [pois]

asiste ensantos deichando de[uiuer] na

\footnotetext{
${ }^{27}$ Na margem superior, à esquerda, há a seguinte anotação tardia: São Paulo | 1 - 4 - 710. À direita, há uma marca redonda do carimbo do Arquivo Histórico Colonial.
} 
86

||1v. $\|$

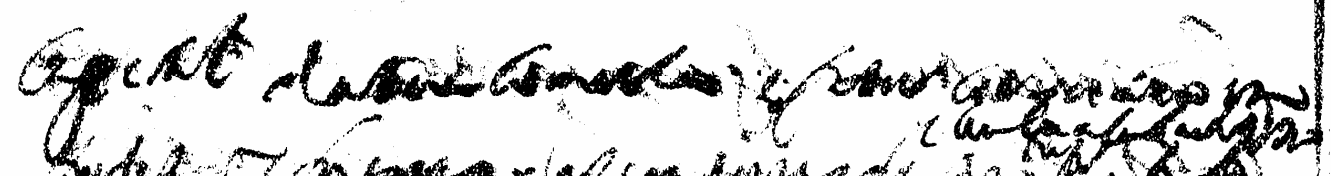

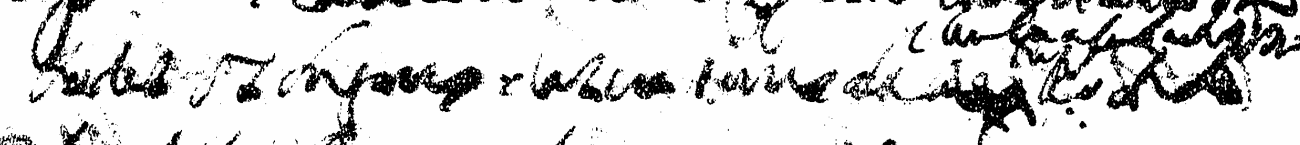

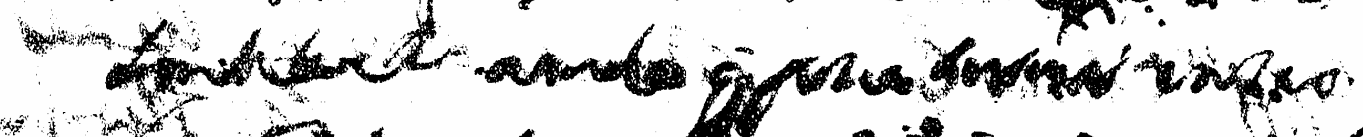

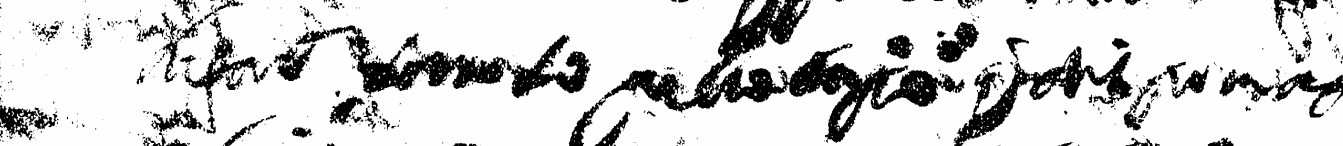

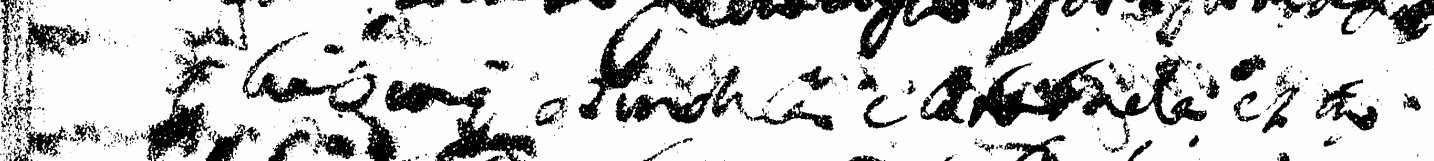

- dicios

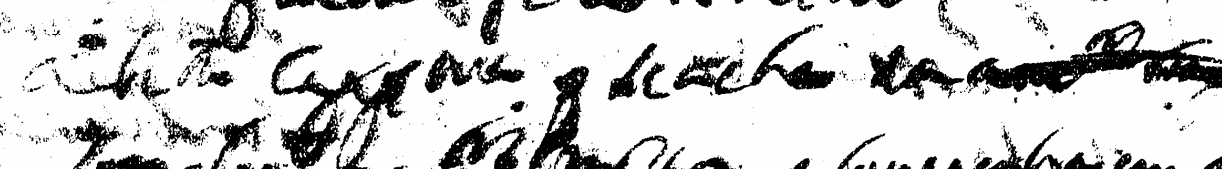

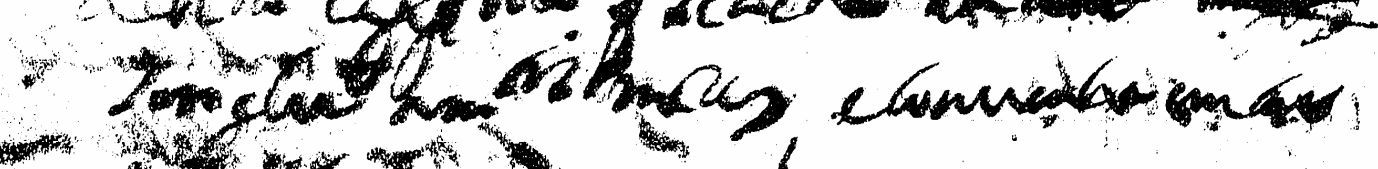

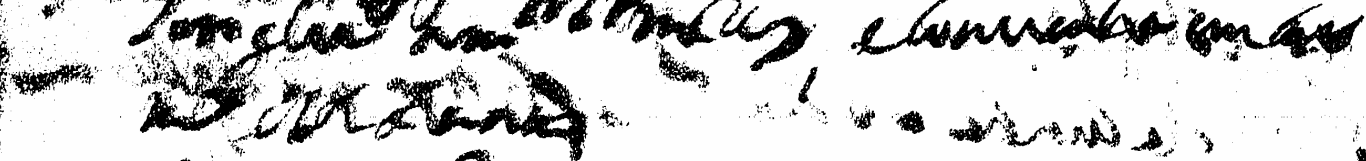

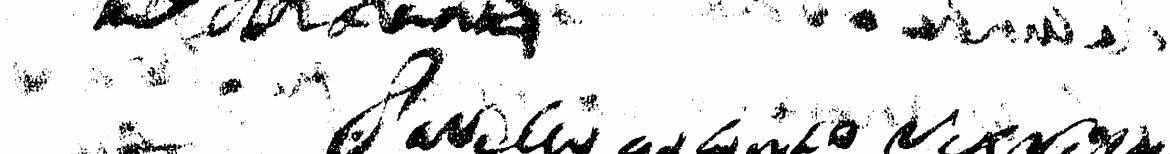

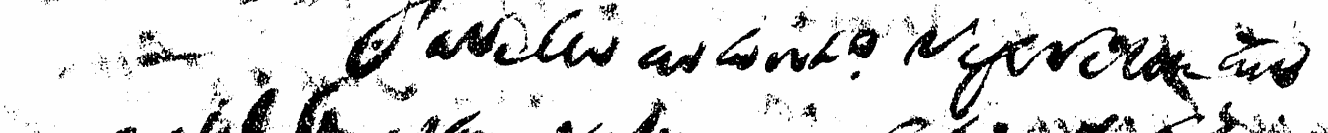

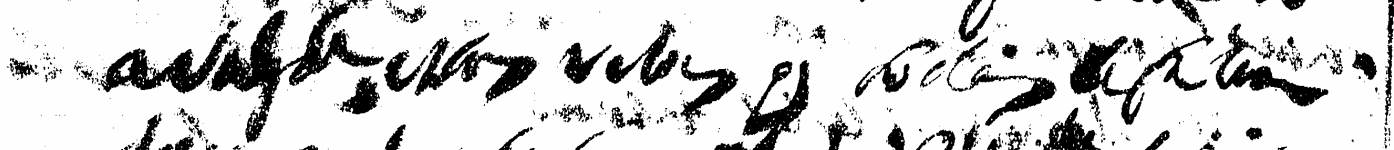

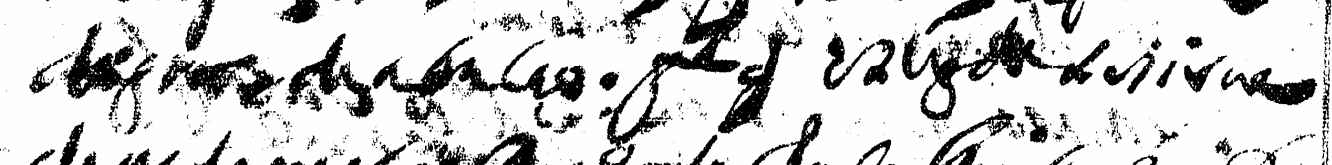

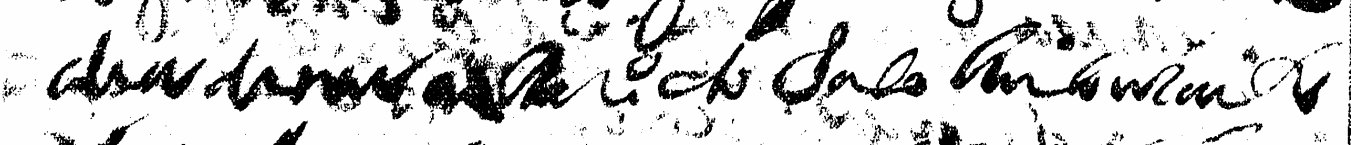

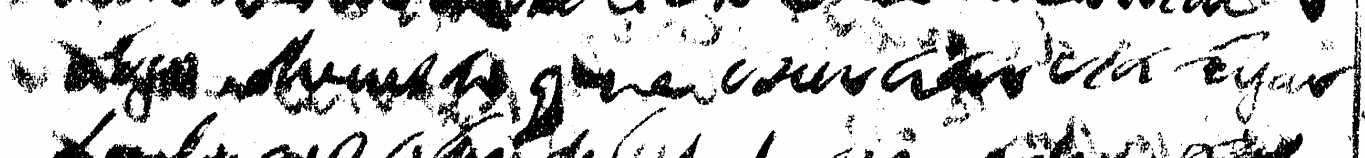

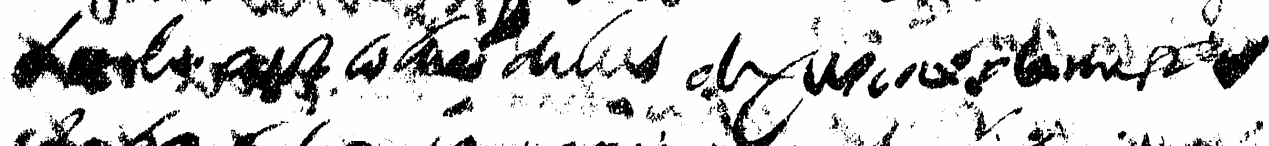

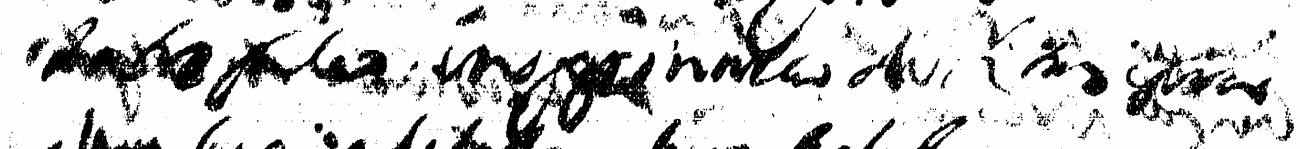

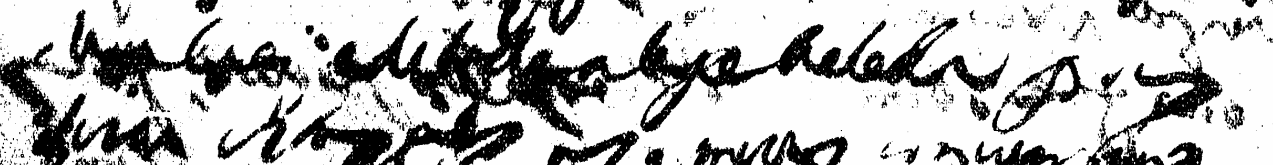

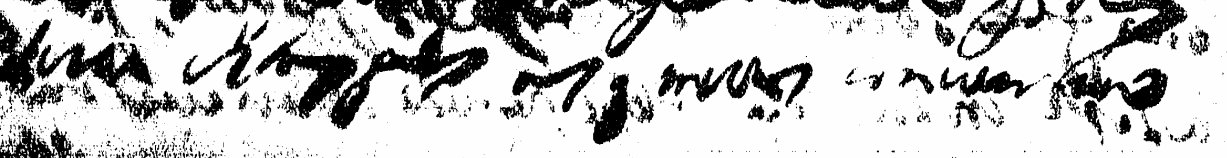




$$
\text { \|1v. }
$$

Capital dasua Com[arca] e faser [CorreCao] en

todos os Lugares dasua iurisdiCaoda $<$ [elle Ia aCabadono] $>$ ao dito

sindiCante ainda que possa seruir enseo

Lugar sera so pello [tenpo] que dispoen aLe[y]

5 que heo enque osindiCa e [ia] [aCabada] esta

dilligenCia fica totalmente sen ministro

a dita Cappitania que se acha ia amuitos tempos

sem elleamuitos mezes eConuenha euitar

[ilegível] este [danno]

Pareceo ao Conselho representar

aVossaMagestade estas resoes que todas se fasen

dignas de atenCao para que VossaMagestade sesirua

deordenar aoDezembargador do PaCo lheConsulte

Logo Menistro que ua exercitar este Lugar

15 [sendo] aescolha delle depesoa de ma[y]or

satisfaCao enoppin[niao] de[letras] epru

denCia e[uallor] eCapaCidade pois

serao estas partes as que [mais] conuenhao 
88

||2r.|

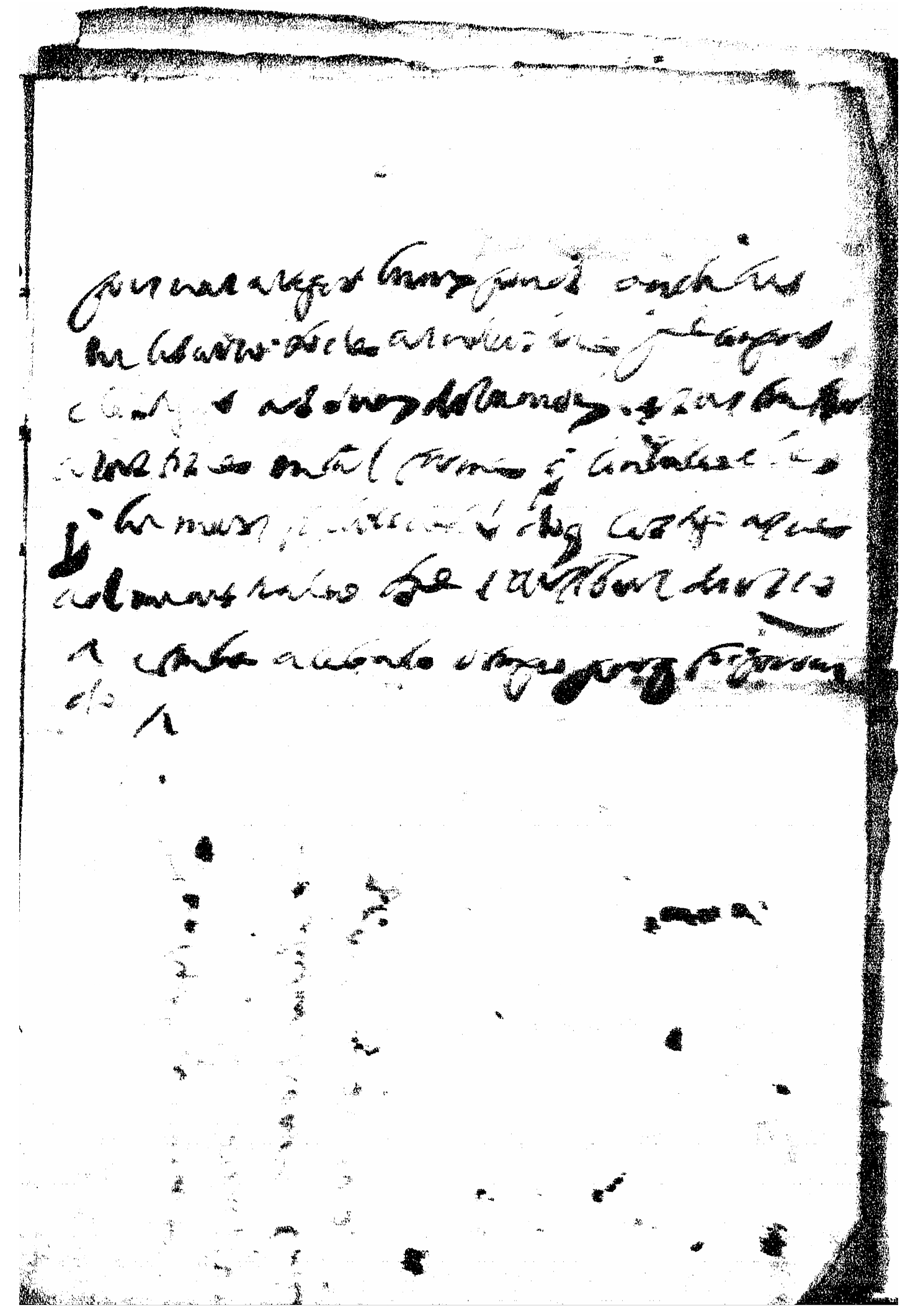


||2r.|

pois uai a[repor] huns pouos onde he

ne Cesario toda aindustria para [conpor]

e [Castigar] as suas [dezunioes] esustentar aiustisa ental forma que [ConheCao] [das]

5 que he [mais] [felliCidade] doque Castigo asua administraCao Lisboa 1 deAbril de 1710

[a etenha] aC[abado] o tempo por que [foiporsua] do 
||2v.||

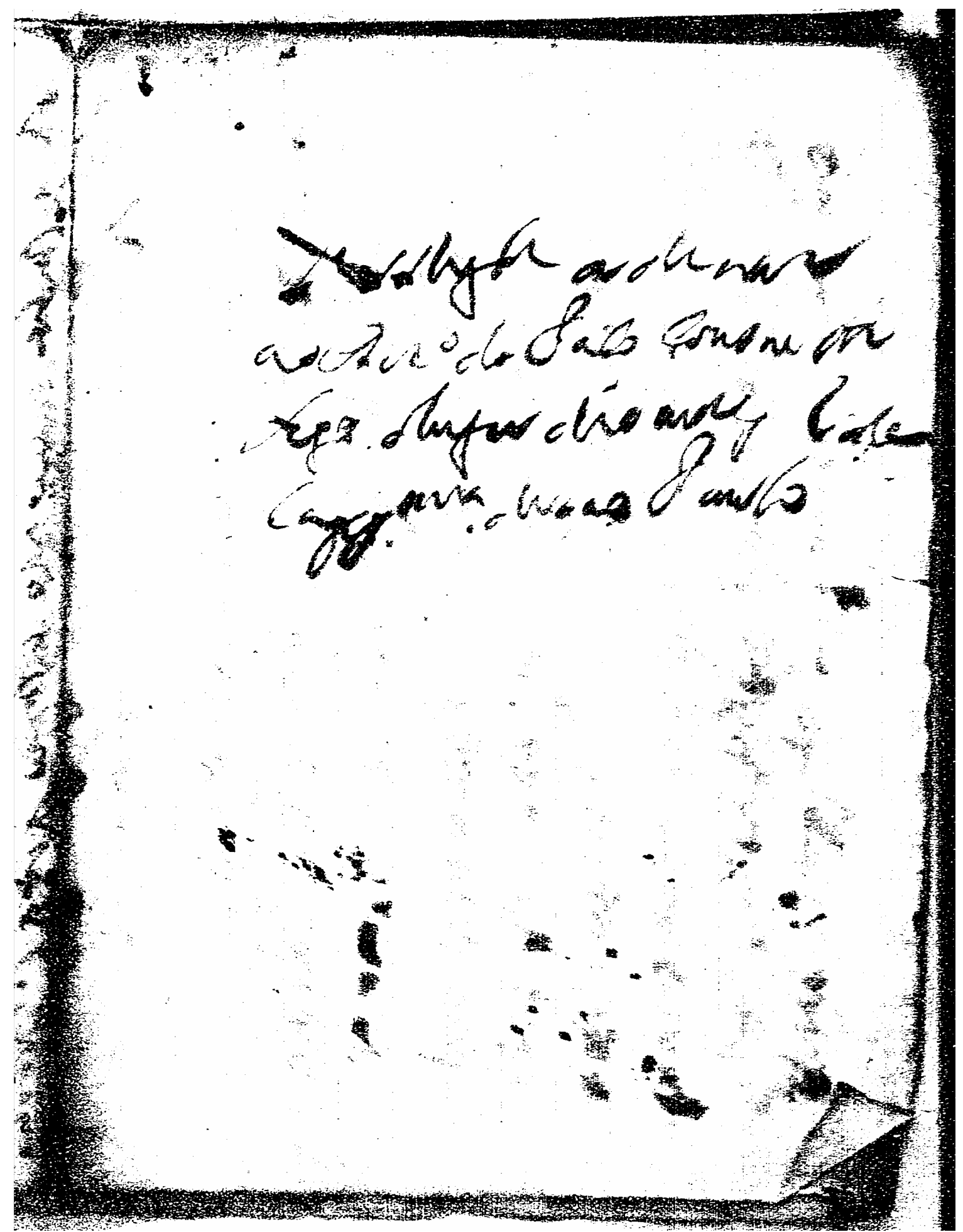


\|2v. $\|$

segue sua Magestade ordenar

ao Dezembargador do Paço Consulte

Logo oLugar deouuidor geral da

Cappitania desao Paulo 
Documento 5: despacho escrito em 20 de dezembro de 1710 em Lisboa, acompanhando requerimento escrito em São Paulo, sem datação.

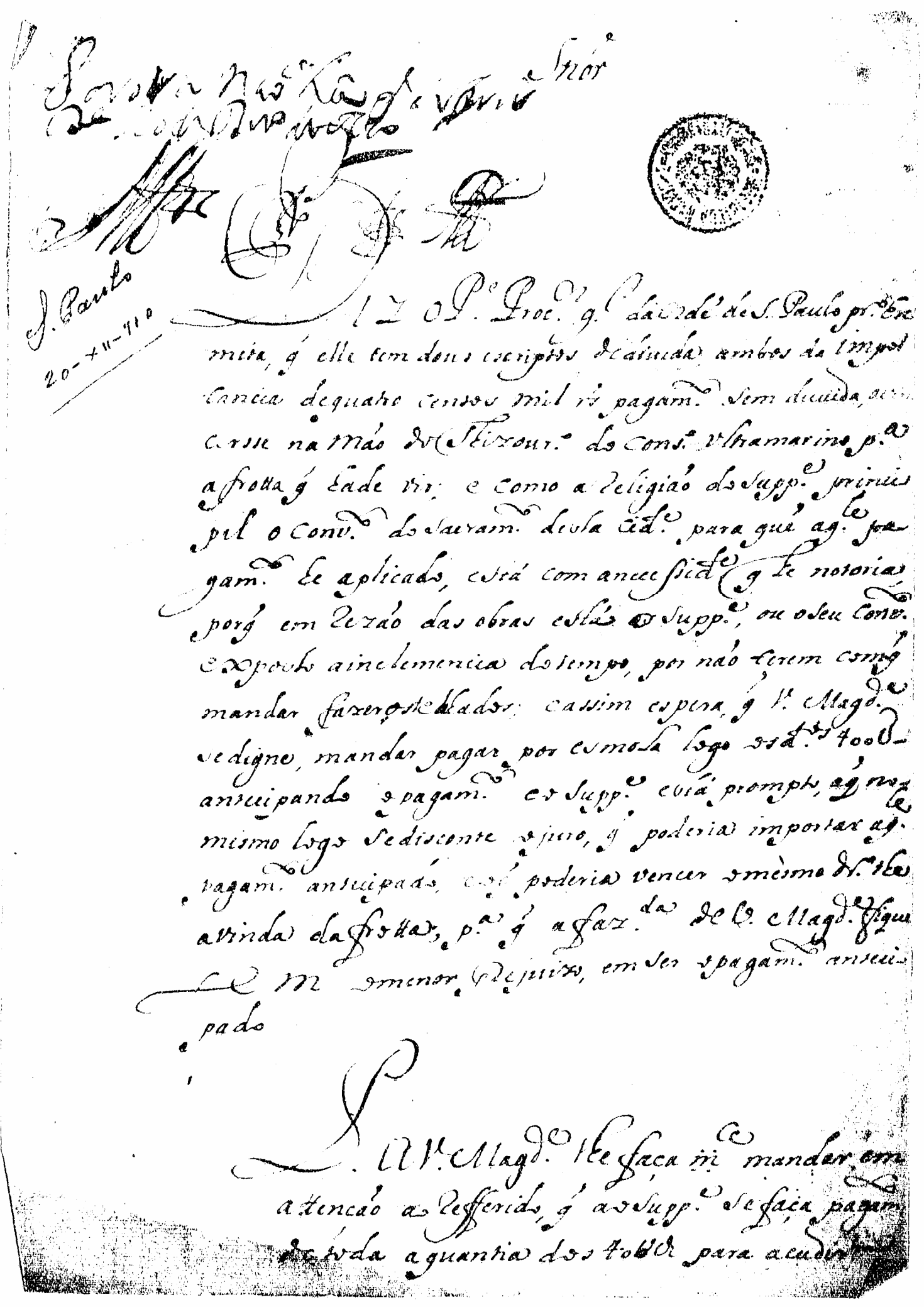




\section{Senhor ${ }^{28}$}

$<$ Por ora não hâ que suprir

Lisboa 20 deDezembro de $\underline{1710}^{29}>$

Diz o Padre Procurador geral da ordẽ de Saõ Paulo primeiro Ere ${ }^{30}$

5 mita, que elle tem dous escriptos de diuida ambos da impor

tancia de quatro centos mil reis pagamento Sem duuida, [acres-]

[cersse] na mão do Thizoureiro do conselho vltramarino para

a frotta que hade vir, e como a religiaõ do Supplicante princi

pal o convento do Sacramento desta cidade para quẽ aquelle pa

10 gamento he aplicado, está com a necessidade que he notoria, porque em rezaõ das obras está o Supplicante, ou o Seu convento exposto a inclemencia do tempo, por naõ terem comque mandar fazer ostelhados; e assim espera, que Vossa Magestade se digne, mandar pagar por esmoLa Logo os dittos 400 mil reis antecipando o pagamento e o Supplicante está prompto, aque nomesmo Logo Se disconte o juro, que poderia importar aquelle pagamento antecipado, e oque poderia vencer o mesmo direito the a vinda da frotta, para que a fazenda de Vossa Magestade fique sem omenor prejuizo, em Ser o pagamento antecipado

Pede a VossaMagestade lhe faça merce mandar em attençaõ ao refferido, que ao Supplicante se faça pagamento de toda a quantia dos 40[0] $\mathrm{mil}^{31}$ [reis] para acudir

\footnotetext{
${ }^{28}$ Abaixo do vocativo, há uma marca redonda do carimbo do Arquivo Histórico Colonial.

${ }^{29}$ Seguem rubricas.

${ }^{30} \mathrm{Na}$ altura dessa linha, na margem esquerda, há a seguinte anotação tardia: "São Paulo | 20 - XII - 710"

${ }^{31}$ No manuscrito, a unidade " 0 " do "400" vem sob a abreviatura por letra especial de mil.
} 
94

$\|\mathbf{1 v}$.
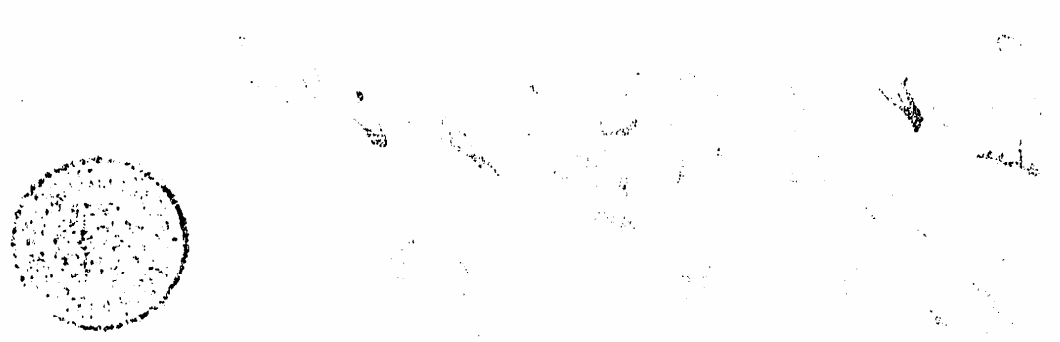

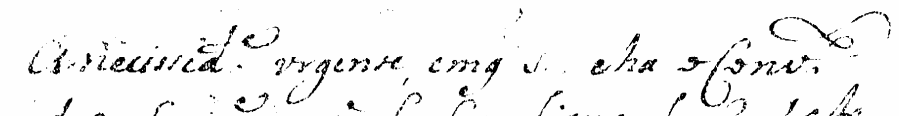

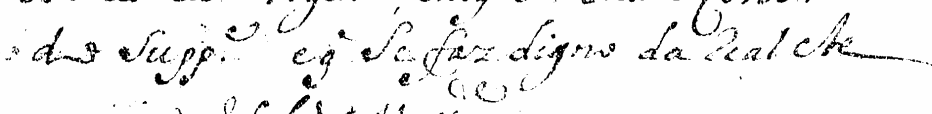

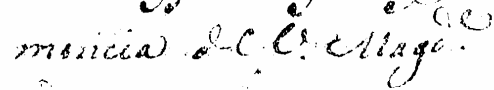

$$
\therefore \text { brencers }
$$

trotas

toras

(t) 


$$
\text { ||1v. }
$$

anecessidade vrgente, em que S[e] [a]cha o Convento

do Supplicante e que Se faz digno da real cle

mencia de Vossa Magestade.

\section{EsperaReceberMerce}


Documento 6: despachos escritos em 6 de junho de 1711 e em 17 de março de 1711, ambos em Lisboa, acompanhando carta de 12 de outubro de 1710 escrita em Vila de Santo Antônio de Guaratinguetá.

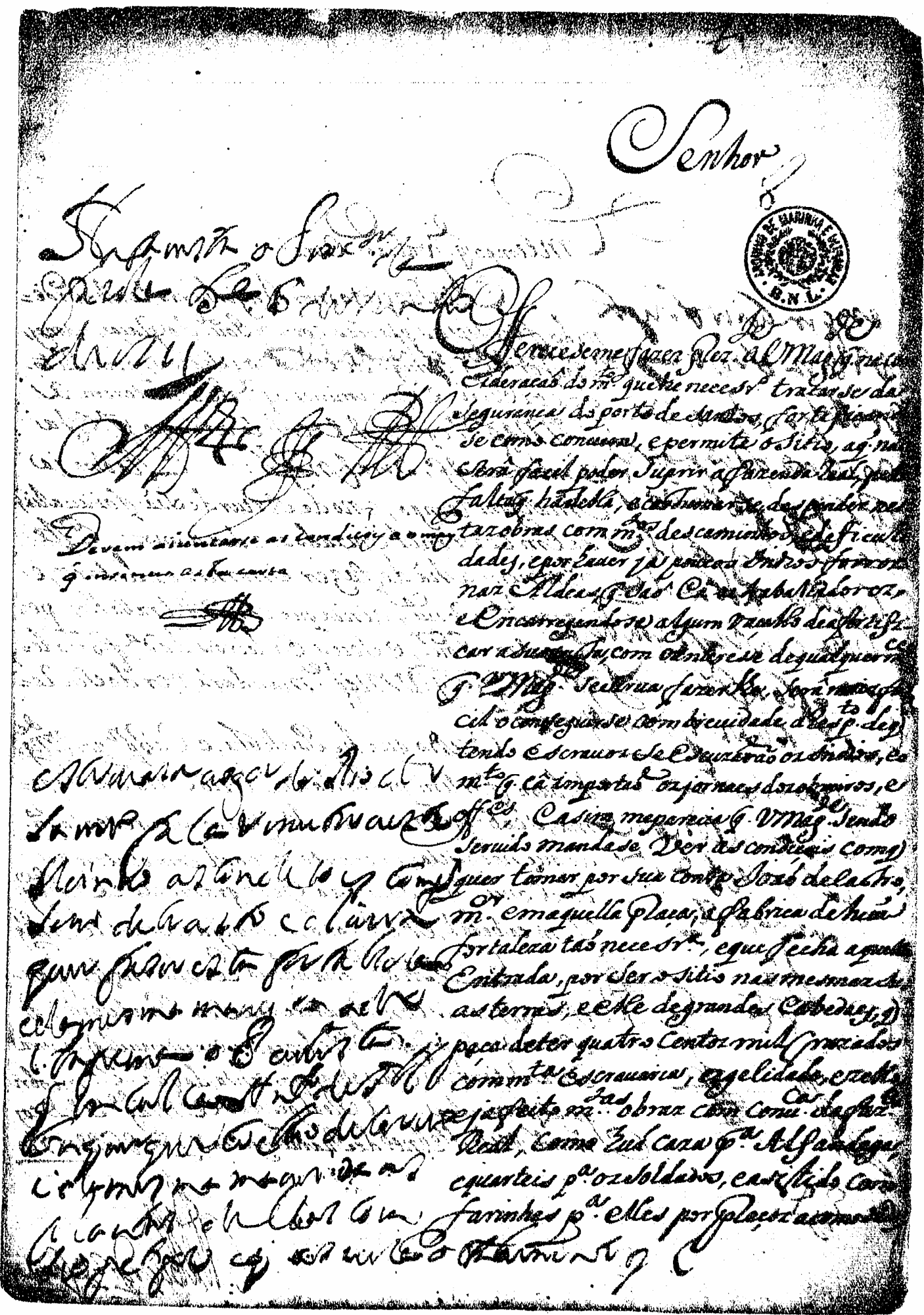


Senhor $^{32}$

$<$ Haja uista o Procurador da

fazenda Lisboa 8 deIunho

de $\left.1711^{33}\right\rangle$

$5<$ Devem aiuntarse as condiçois e o mais que interessar aesta carta ${ }^{34}>$

<escreuese ao gouernador do Rio de

Ianeiro face remeter aeste

Reinno as condicois comque

10 Ioao de Crasto e oliuera

quer faser esta fortalleza

eda mesma maneira ade

Itapema e Paulista

que inCulCa Antonio de $\mathrm{Al}$

15 buquerque Coelho deCarualho

e da mesma manda as

plantas dellas com

seo petipe eque [assim o] [transmite] que o>

Offereceseme fazer prezente aVossaMagestade que na co[n]

20 cideraçaõ do muito quehe necesario tratar se da

Segurança do porto deSantos, fortifica[ndo]

Se como conuem, epermite oSitio aque naõ

Serâ facil poder Suprir afazenda real, pela

faltaque hâdella, e costumarse despender nes

25 tazobras com muitos descaminhos, edeficul

dades, epor haver ja poucos Indios forroz

naz Aldeas, que saõ Cã ostrabalhadorez,

eencarregandose algum vaçallo deafortifi-

car asua custa, com ointerese dequalquer merce

30 que VossaMagestade SeSirua fazer lhe Serâ maiz fa

cil o conseguirse com breuidade a resposta deque

tendo escrauos Seescuzaraõ ozIndios, eo

muito que câ importaõ ozjornaes doz obreiros, e

officiaes, Casim meparecia que VossaMagestade Sendo

35 Seruido mandase Ver as condiçois comque

quer tomar por Sua conta Ioaõ deCastro,

morador em aquella praça, afabrica dehuã

fortaleza taõ necesaria, eque fecha aquella

Entrada, por Ser oSitio nas mesmazSu

40 as terras, eelle degrandes Cabedaes, que

paça deter quatro Centoz mil Cruzados

com muita Escrauaria, eagelidade, ezello

ejafeito muitas obraz com conuenienca dafazenda

Real, como huã caza para Alfandega,

45 equarteis para ozSoldados, easitido com

farinhas para elles por preçoz acomodados

\footnotetext{
${ }^{32}$ Abaixo do vocativo, há uma marca redonda do carimbo do Arquivo de Marinha e Ultramar.

${ }^{33}$ Seguem rubricas.

${ }^{34}$ Segue rubrica.
} 
||1v.|

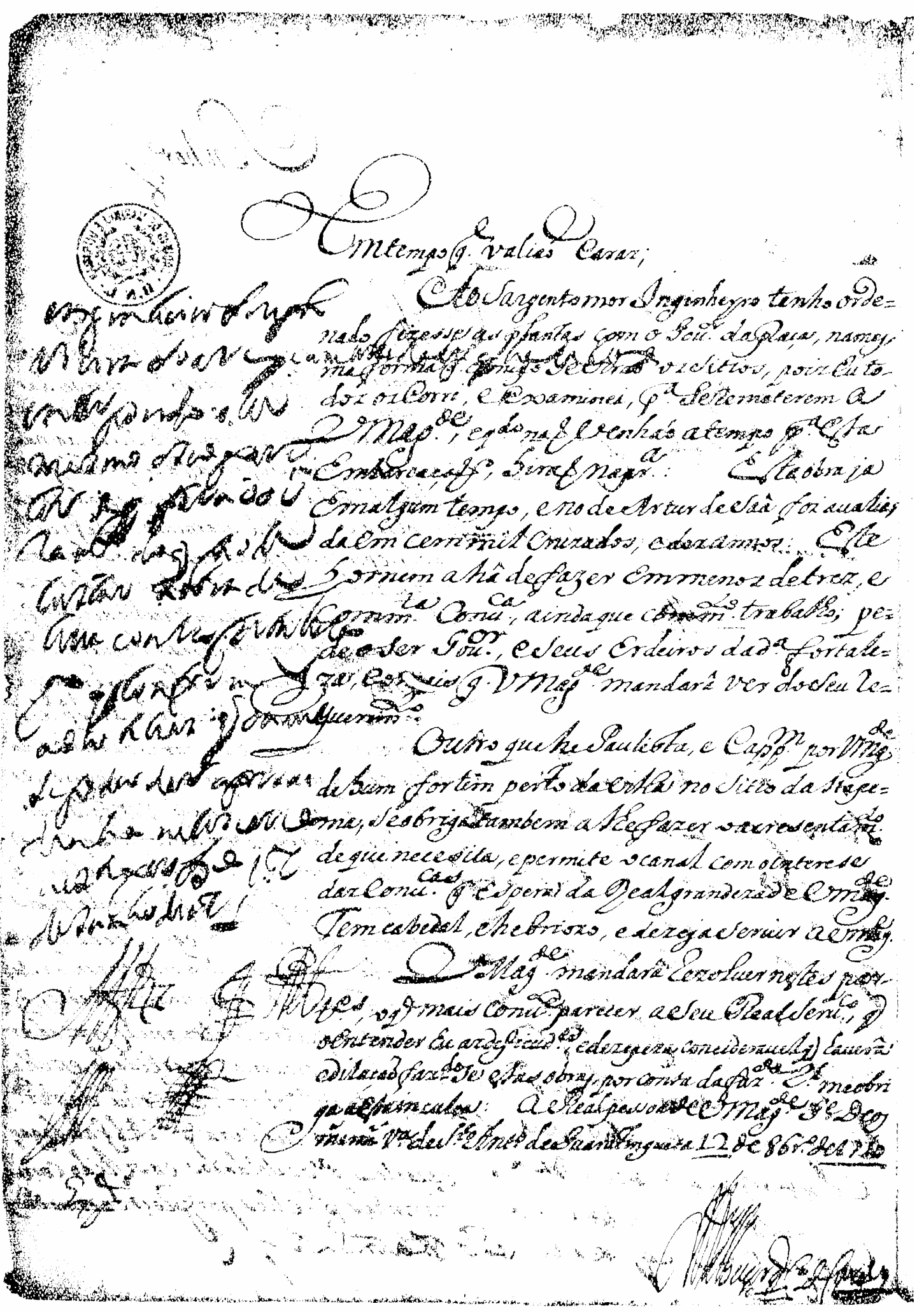


<engenheiroIoseph ${ }^{35}$

$\|1 \mathrm{v}$.

Vieira Soares

interpondo der

mesmo oseo pare

5 cer oque fara [dou]

[zar] doque pode

Custar aobra de

Cima eoutra fortaleza

para queconfiram

10 as[notiCias] [ilegível] que [ouuer]

sepoder dar apr[o]va

[dinha] necesaria

neste [parecer] Lisboa 17

deIunho de $1711^{36}>$

15 Emtempo que valiaõ Caraz;

Ao Sargento mor Ingenheyro tenho orde=

nado fizesse as plantas com oGouernador dapraça, names-

maforma que comigo Seuiraõ osSitios, poizEu to-

doz osCorri, eexaminei, paraSeremeterem a

20 VossaMagestade, equando naõvenhaõ atempo paraesta

Embarcaçaõ, hiraõnaproxima: Esta obra ja

Emalgum tempo, eno deArtur de Saâ foi aualia-

daem cem mil cruzados, edez annos: Este

homem ahâ defazer Emmenos detrez, e

25 commuita Conuenienca, aindaque commuito trabalho; pe=

de oSer Gouernador, eSeus Erdeiros daditafortale=

za, eos meios que VossaMagestade mandarâ ver doSeu re=

querimento.

Outro quehe Paulista, e Cappitam por VossaMagestade

30 dehum fortim perto davilla no Sitio daItape= ma, Seobrigatambem alhefazer oacresentamento deque necesita, e permite o canal com o interese dazConueniencas que Espera daRealgrandezadeVossaMagestade Tem cabedal, ehebriozo, edezejaSeruir aVossaMagestade

35 VossaMagestade mandarâ rezoluer nestes particulares, o que mais conueniente parecer aSeuRealSeruico, que oEntender Eu azdeficudades edezepeza conciderauelque hauerâ edilaçaõ fazendoSe estas obras por conta dafazenda real meobri ga aEstainculca: aRealpessoadeVossaMagestade Guarde Deos

40 muitosannos Villa de Santo Antonio deGuaratingueta $\underline{12}$ de outubro de1710 AntoniodeAlbuquerquedeCoelhodeCarualho

\footnotetext{
${ }^{35}$ Acima dessa linha, há uma marca redonda do carimbo do Arquivo de Marinha e Ultramar.

${ }^{36}$ Seguem rubricas.
} 
Documento 7: despacho escrito em 3 de agosto de 1711 em Lisboa, acompanhando carta de 8 de setembro de 1710, escrita em Santos.

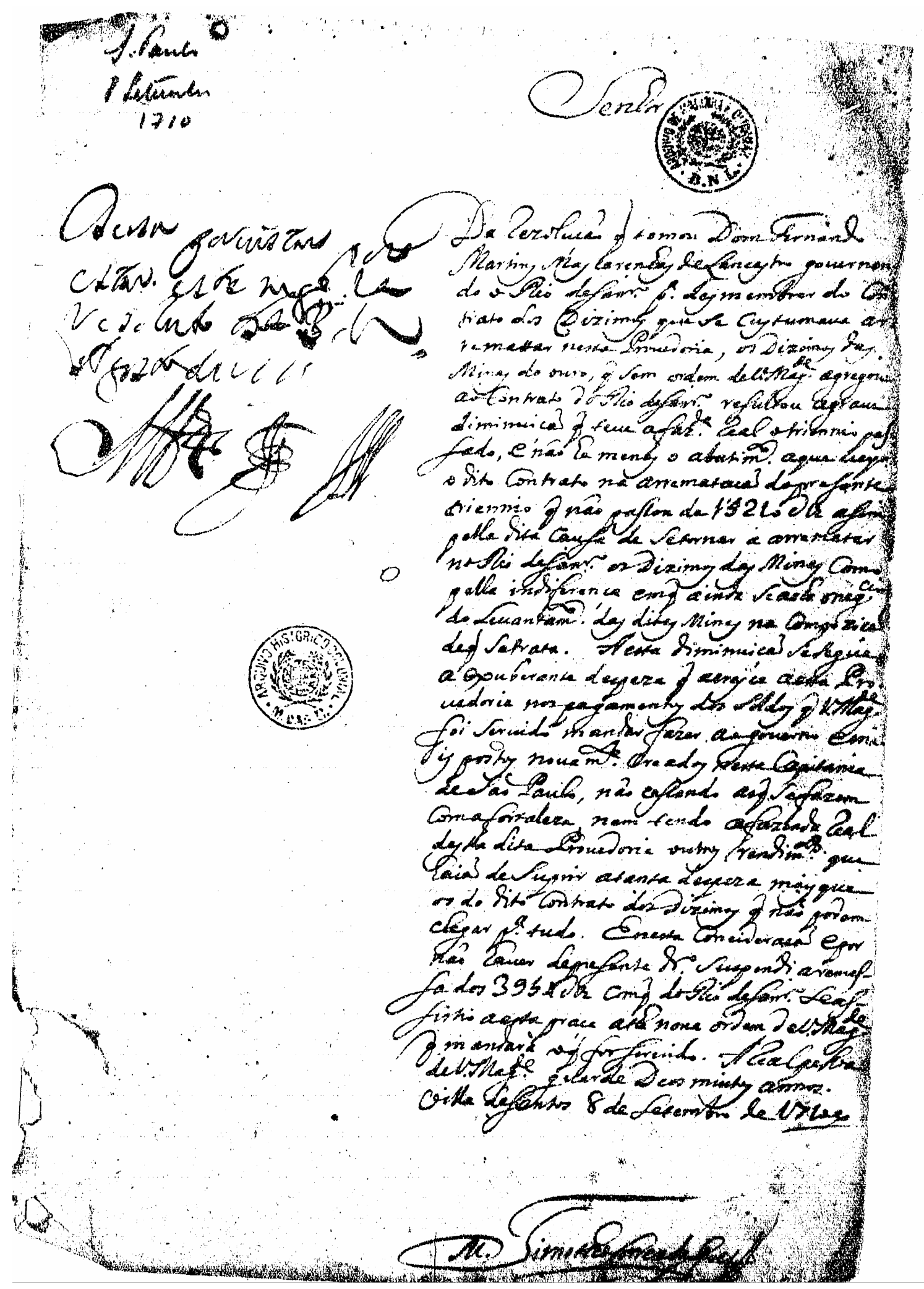


Senhor $^{37}$

$<$ [Deem] por uistar por

estar este neg[ocio] Ia

resoluto Lisboa 3 de

5 Agosto de $1711^{38}>$

Da rezoluçaõ que tomou Dom Fernando

Martins Mas Carenhas deLancastro gouernan

do o Rio deJaneiro para desmembrar do Con

trato dos Dizimos que Se Custumaua ar

10 remattar nesta Prouedoria, os Dizimos das

Minas do ouro, que Sem ordem deVossaMagestade agregou

aoContrato doRio deJaneiro resultou agraue

diminuiçaõ que teue afazenda real o triennio pas

sado, e não ha menos o abatimento aque [ueyo]

15 o dito Contrato na arremataçaõ dopresente

triennio que não passou de 15210 mil reis asim

pella dita Causa de Setornar a arrematar

noRio deJaneiro osDizimos das Minas Como

pella indiferença emque ainda Se acha onegocio

20 do Leuantamento das ditas Minas na Compoziçaõ

deque Setrata. A esta diminuiçaõ Sesegue ${ }^{39}$

a exuberante despeza que caresia aesta Pro

uedoria nospagamentos dos Soldos que VossaMagestade

foi Seruido mandar fazer aogouerno e ma

25 is postos nouamente creados nestaCapitania

deSaõ Paulo, não cassando asque Sefazem

Comafortaleza, nem tendo afazenda real

desta ditaProuedoria outros rendimentos que

haiaõ deSuprir atanta despeza mais que

30 os do dito Contrato dosDizimos que naõ podem

chegar para tudo. Enesta Concideraçaõ epor

naõ hauer depresente direito Suspendi aremes-

sa dos 3954 mil reis dos com emque doRio deJaneiro Seas-

sistio aesta praça athe noua ordem deVossaMagestade

35 que mandara oque forseruido. A realpessoa

deVossa Magestade guarde Deos muitos annos.

villa desantos 8 de setembro de 1710

TimotheoCorreadeGoes $^{40}$

\footnotetext{
${ }^{37} \mathrm{Na}$ margem superior esquerda, há a seguinte anotação tardia: "São Paulo | 8 Setembro | 1710”. Entre o vocativo e o início do texto, há uma marca redonda do carimbo do Arquivo Histórico Colonial.

${ }^{38}$ Seguem rubricas.

${ }^{39} \mathrm{Na}$ altura dessa linha, na margem esquerda, há uma marca redonda carimbo do Arquivo Histórico Colonial.

${ }^{40}$ Antes da assinatura, há uma rubrica.
} 
102

Documento 8: minuta de parecer escrita em 9 de março de 1712

$\int$

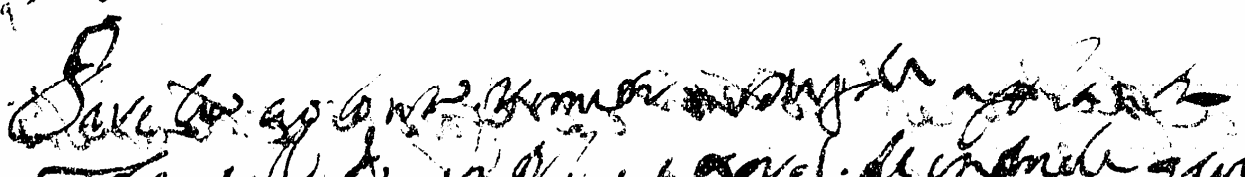

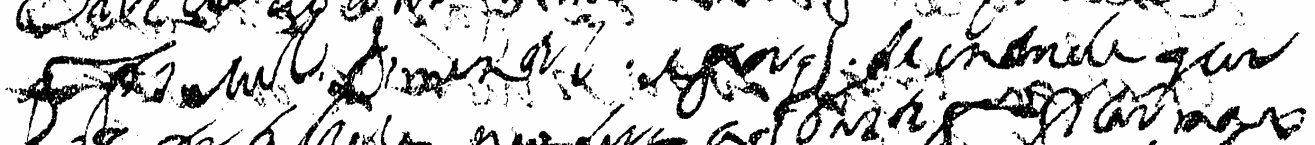

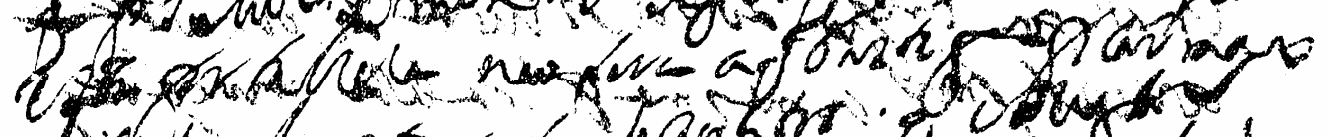

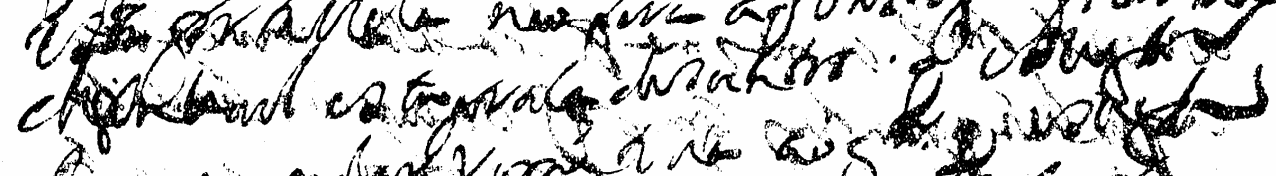

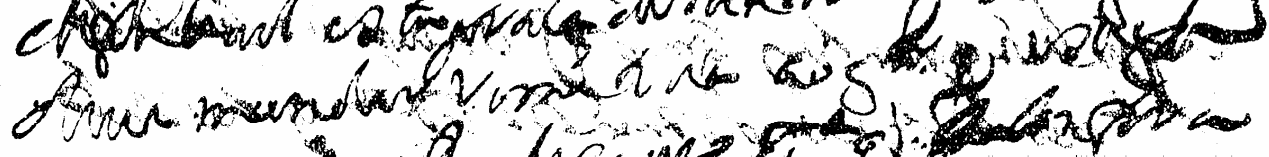

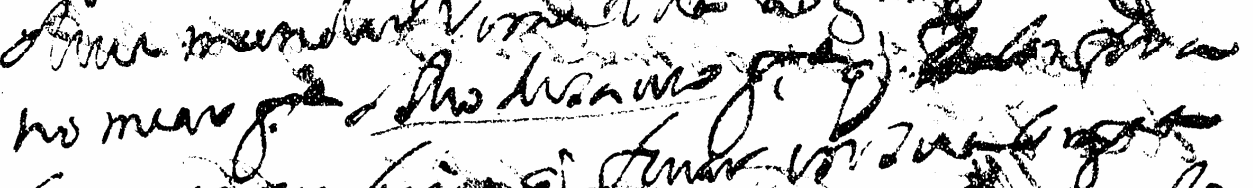

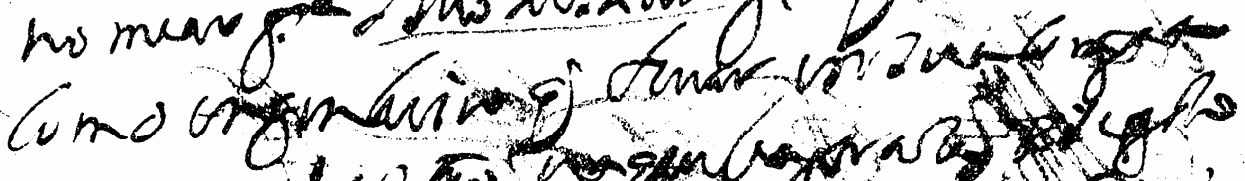

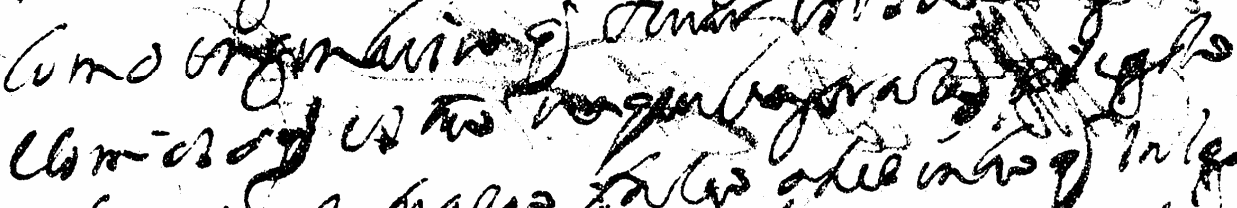

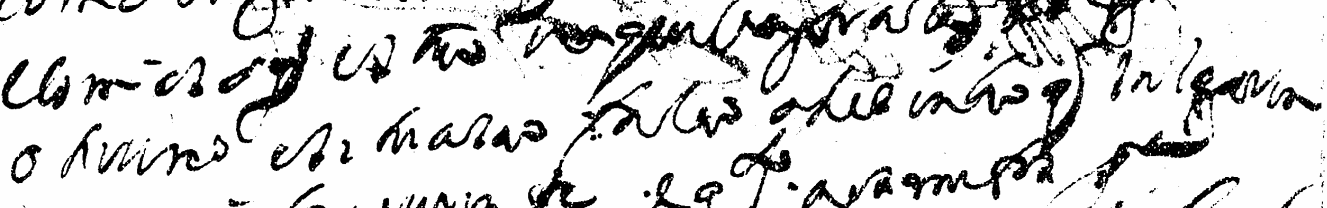

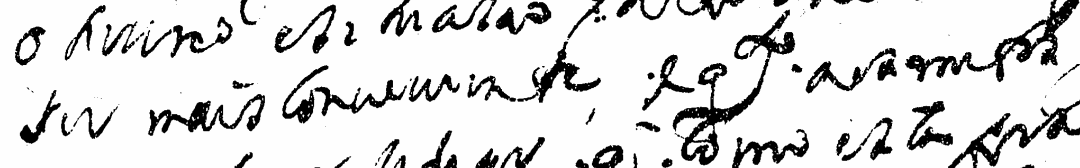

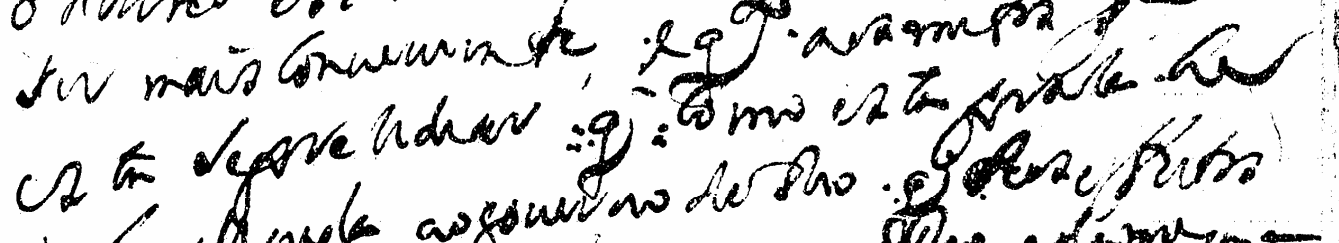

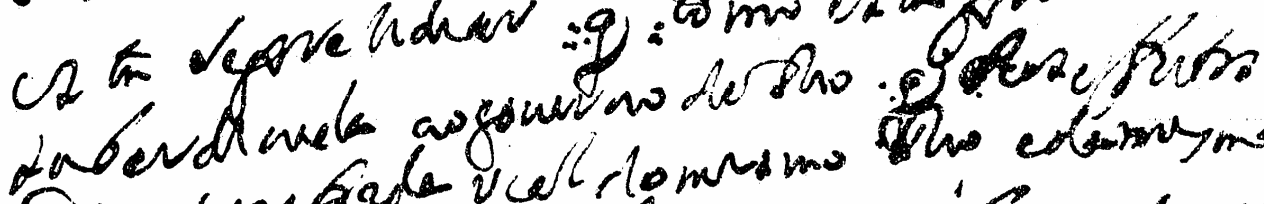

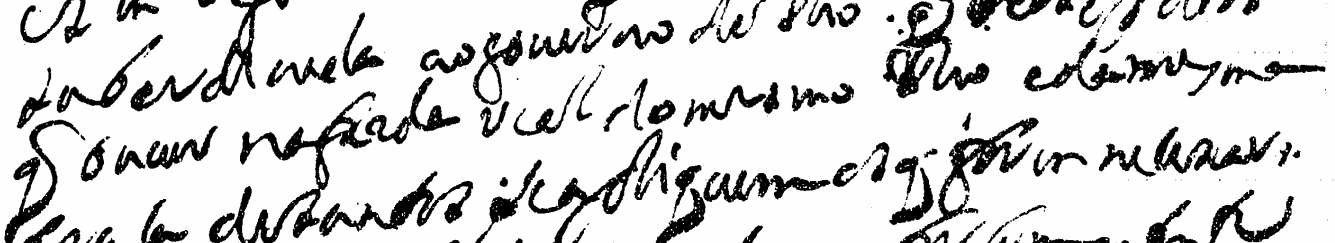

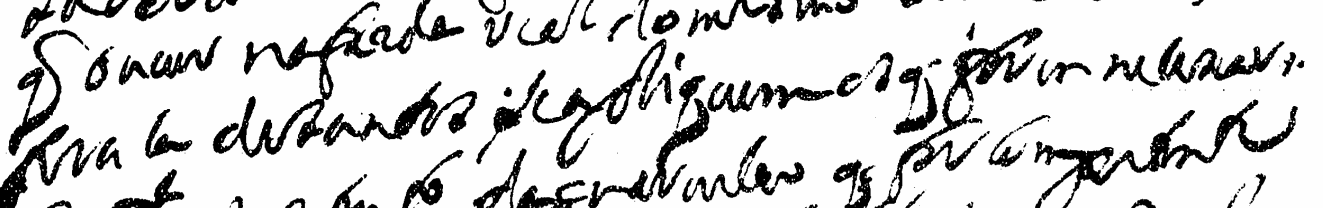

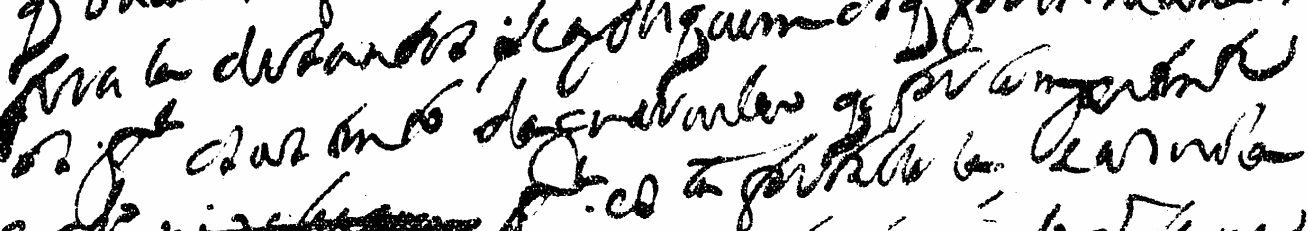

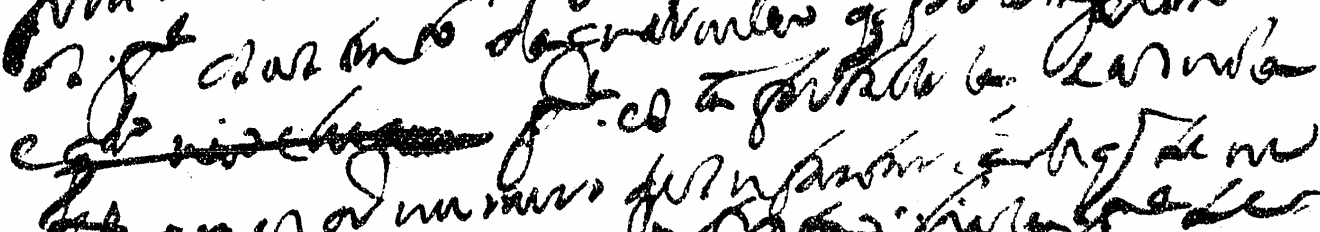

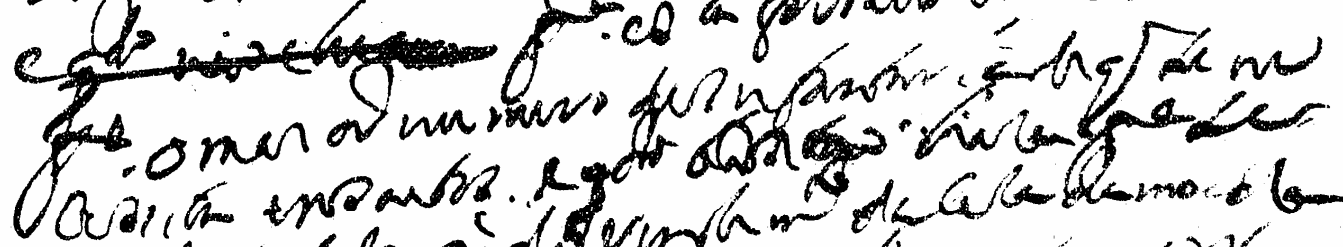

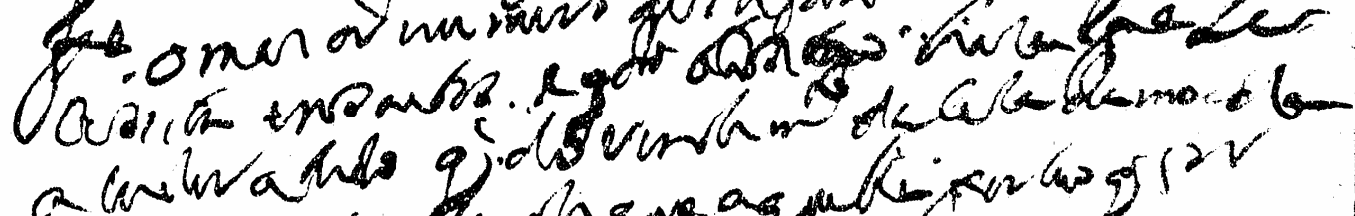

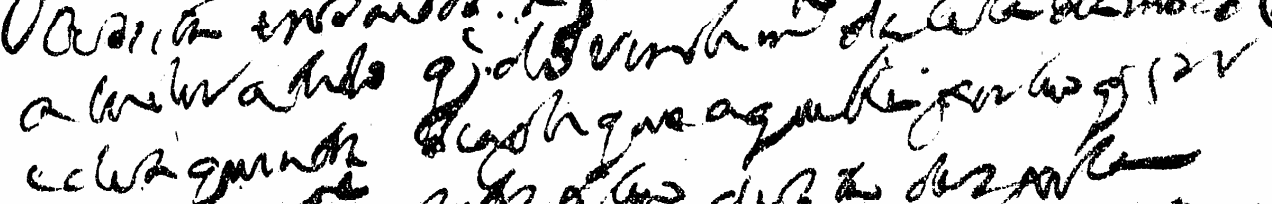

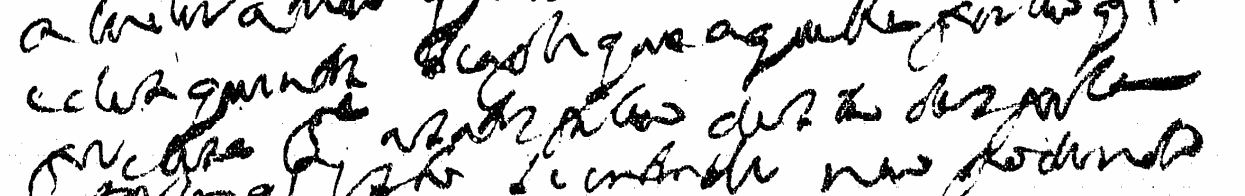

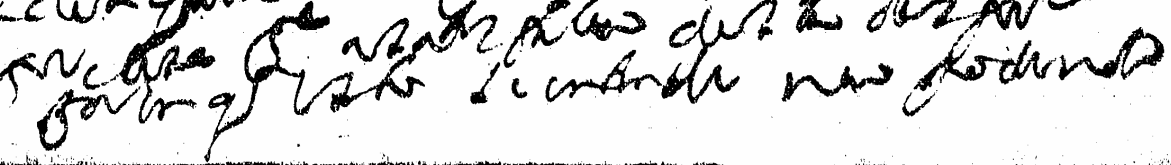


Pareceo ao Conselho remeter aVossaMagestade aplanta ${ }^{41}$

quefes Manoel Pimentel epor que se entende que esta fortallesa nao sera a que baste para ficar maes [defenCauel] esta praca desantos que VossaMagestade

5 deue mandar remete[1]la ao gouernador que VossaMagestade nomear para o Rio deianeiro para que [Se] Confira Como engenheiro que leuar ensuaCompanhia ecom [esa] que estao naquellaprasa e seguro o [terreno] esituasao faCao odesenho que Iulgaren

10 ser mais conueniente, e quanto aos [paga]mentos para esta seprezidiar que Como esta praCa he saber de auela ao gouerno doRio que dos effeitos que ouuer nafazenda real do mesmo Rio edamesma praCa desantos seapliquem os que forem necesari

15 os para osustento daguarnicao que for Competente e quando não cheguem para estafortalleza, e asaida para o maior numero deInfantarias e que se ne Cessita ensantos e quando $<$ naõ $>{ }^{42}$ bastao hera para se aCudir atudo que do rendimento daCaza da moeda

20 e dos quintos seaplique aquella percao que [for] precisa para asatisfacao desta despesa poren queisto se entende não podendo

${ }^{41}$ Acima da mancha, à esquerda, há a seguinte anotação tardia: "Saõ Paulo | 9-9-712".

${ }^{42} \mathrm{O}$ advérbio de negação aparece sobre a palavra "basta", indicando correção de próprio punho. 


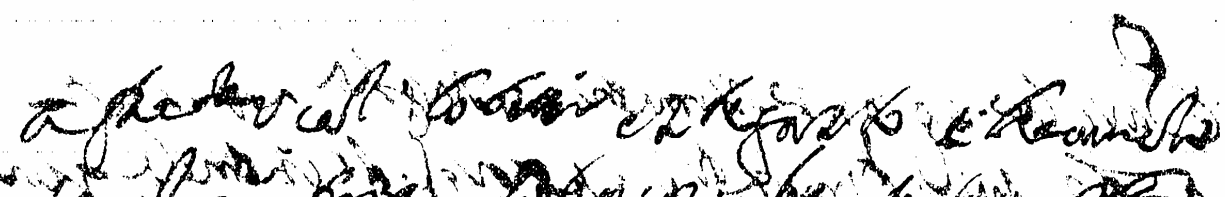

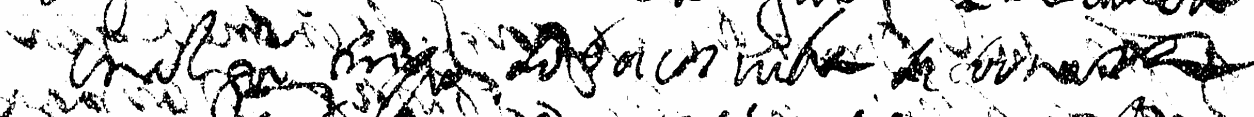

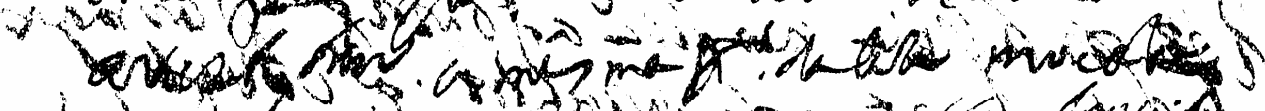

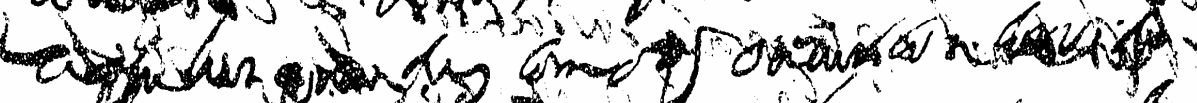

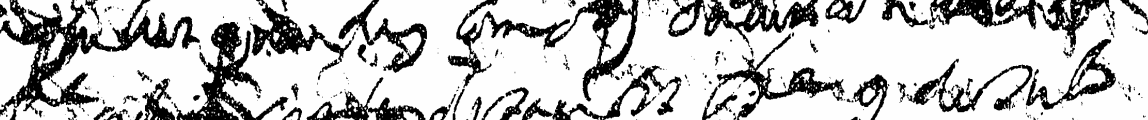

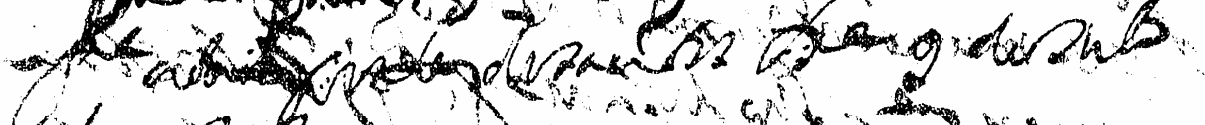
$6 x+2$.

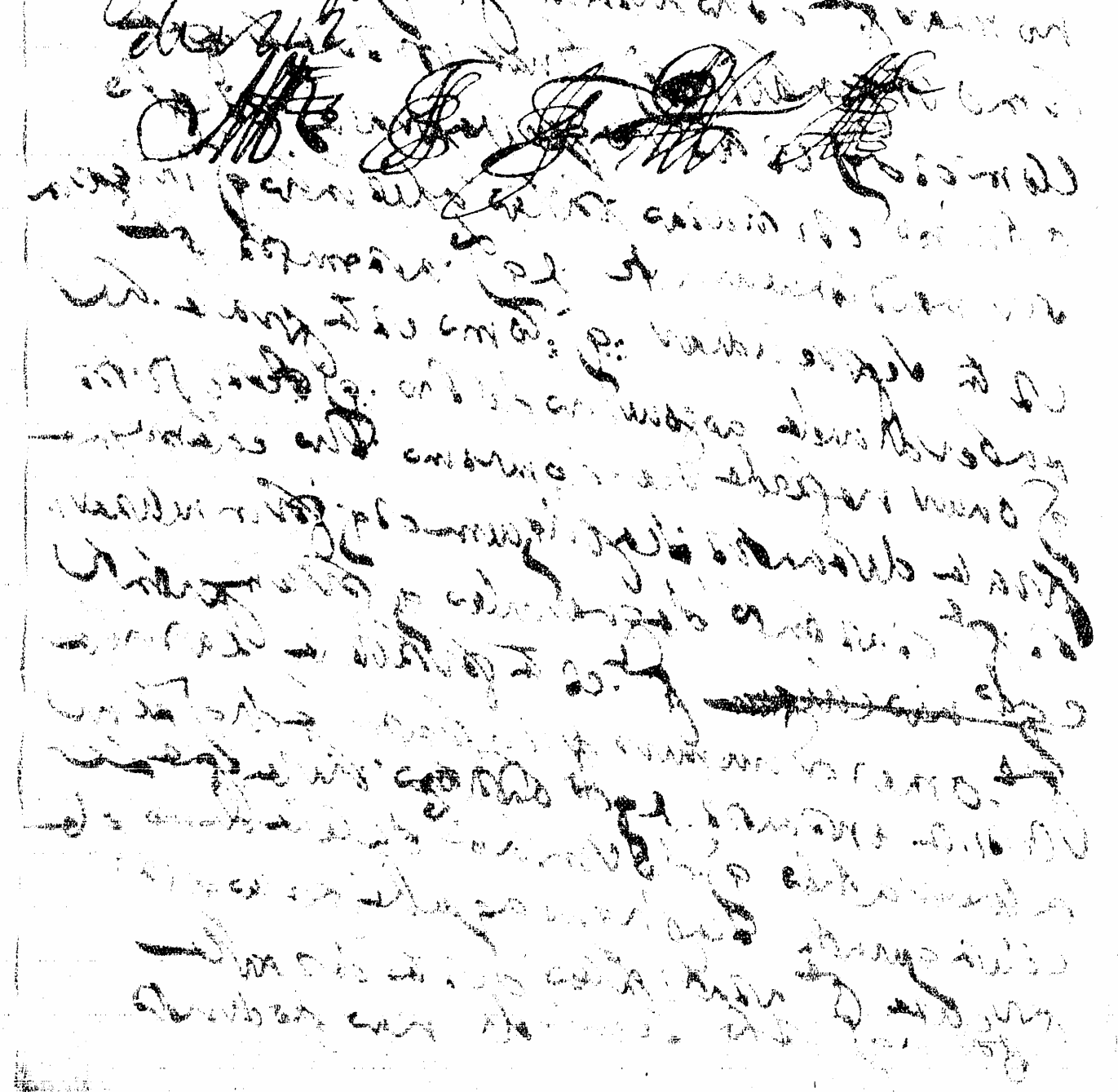




$$
\text { ||1v. }
$$

a fazenda real Cobrar estegasto e hauendo

enalgu tempo sob a [ilegível]ha se tornasse

oresto sem a mesma que daCaza moeda

aquelles quintos Comoque o auer Concorrido

5 para a ditta praca desantos Lisboa 9 deMarCo

de $1712^{43}$

\footnotetext{
${ }^{43}$ Seguem rubricas.
} 
106

Documento 9: abertura da minuta de parecer escrito em 10 de junho de 1712 em Lisboa

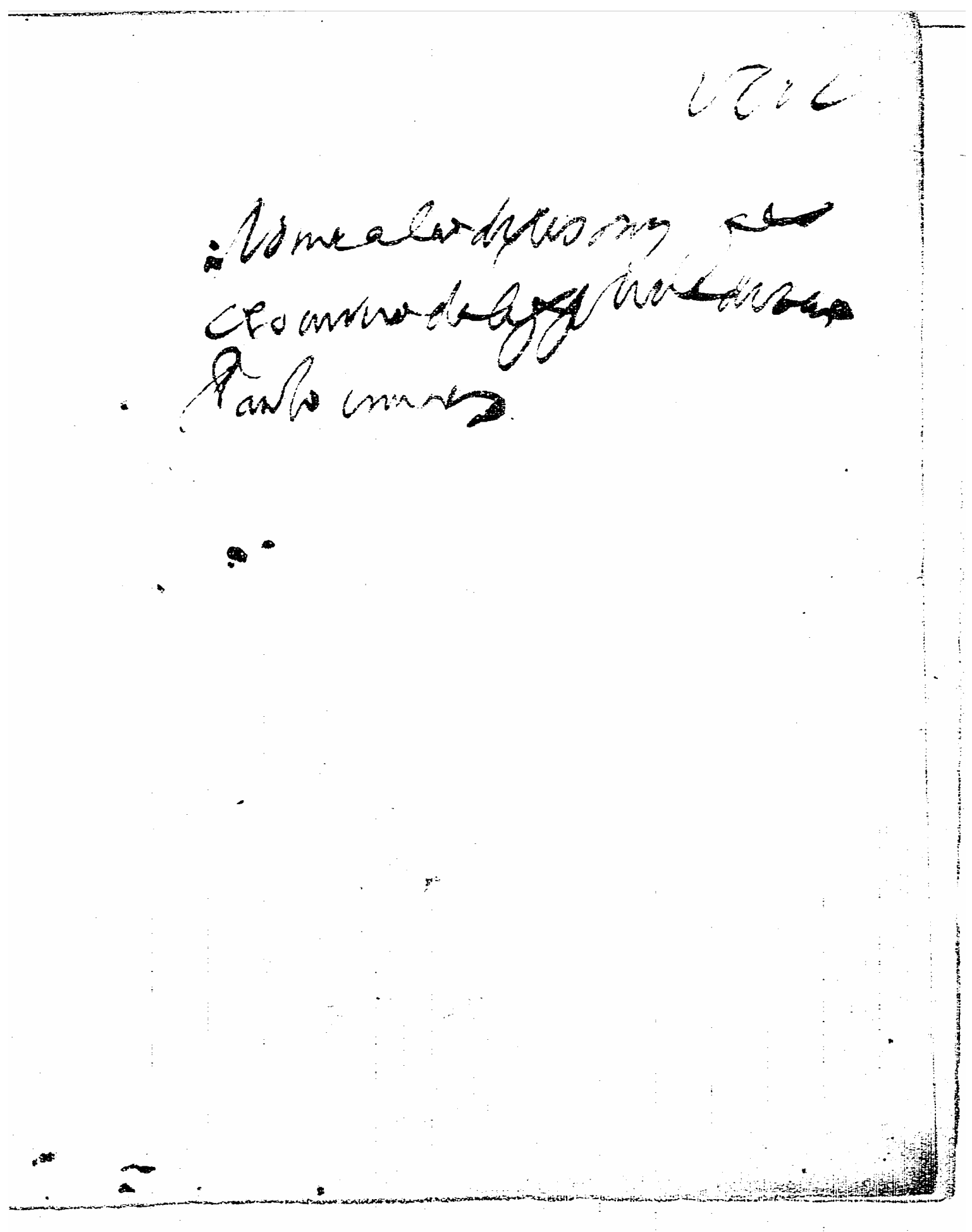


NomeaCao depesoas para

o[g]ouernodaCappitaniadesao

Paulo eminas 
108

$\|1 \mathrm{v}$.

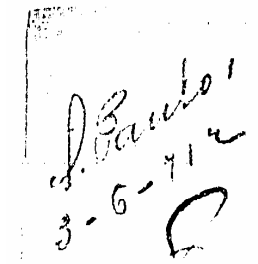

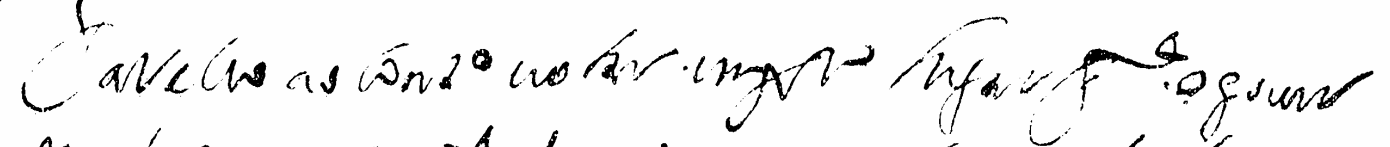

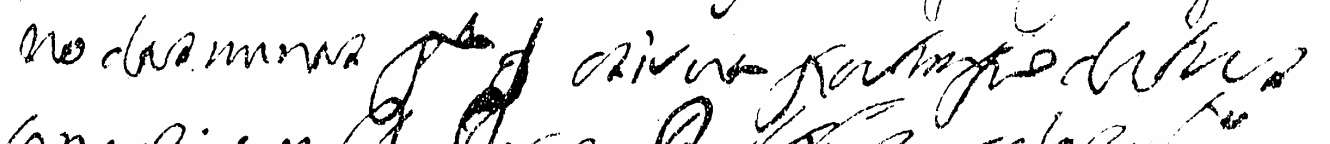

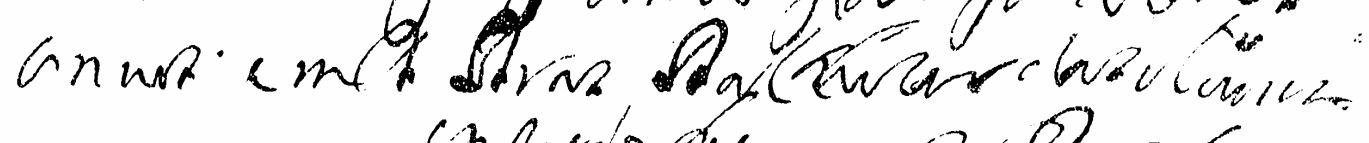

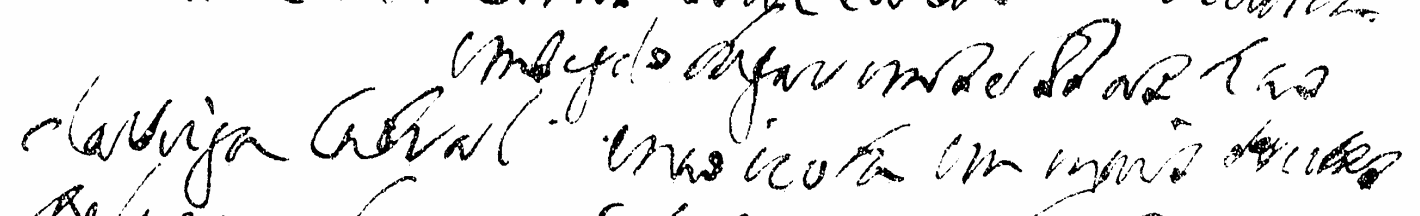

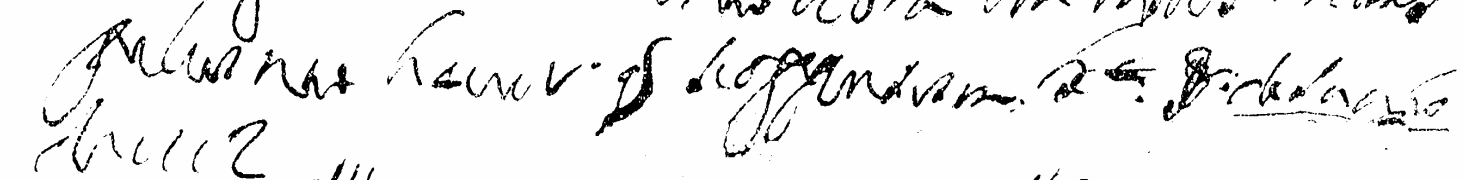
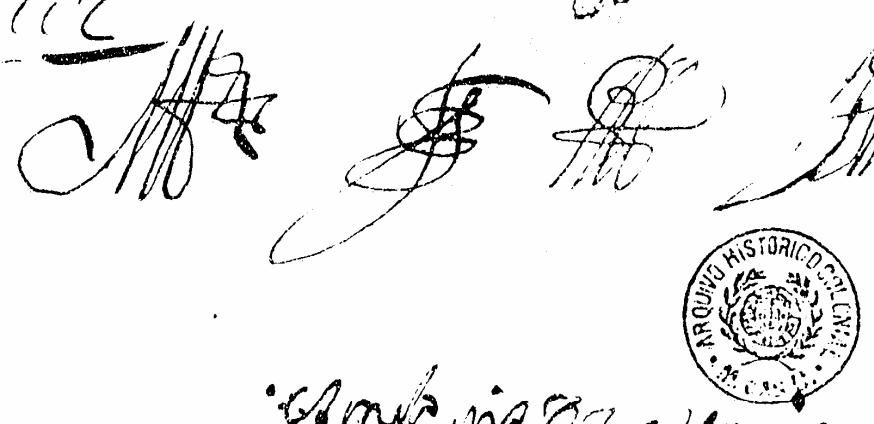

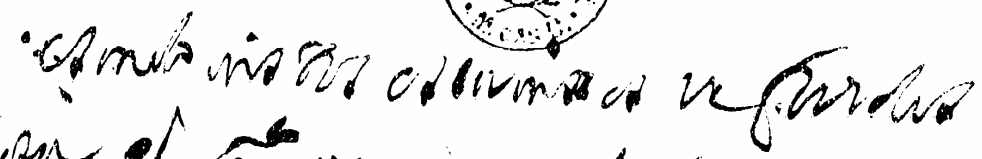

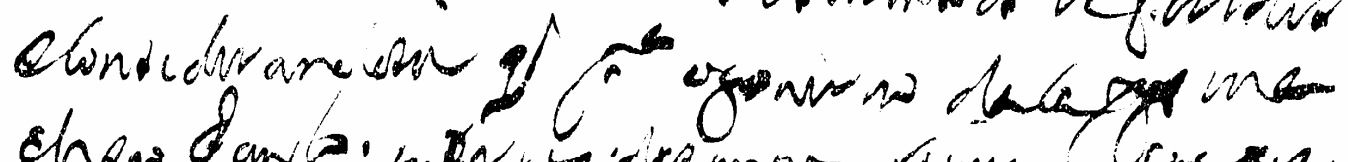

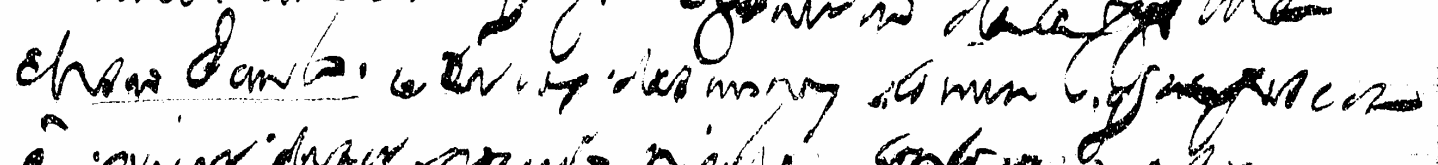

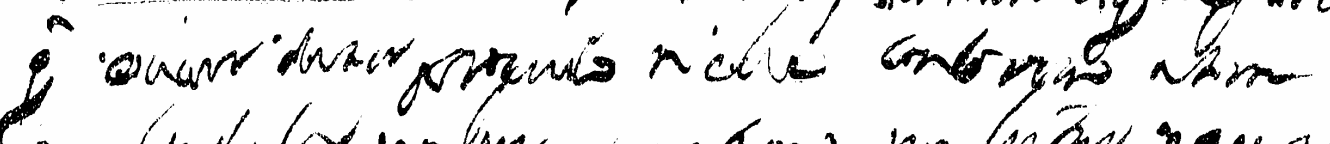

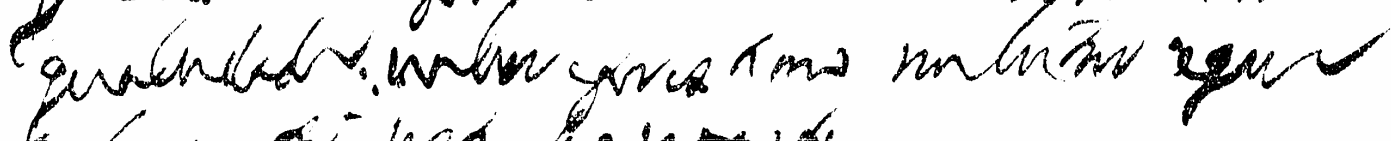

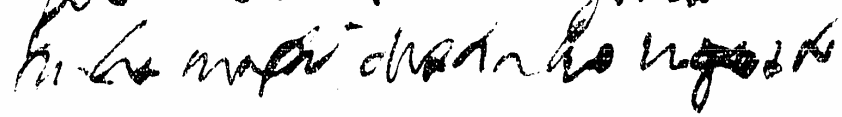




$$
\|1 \mathrm{v} .\|
$$

PareCeo ao Conselho uotar emprimeiro Lugar para o gouer ${ }^{44}$

no das minas para que osirua pertempo detres

annos emDom Balthezar dasilueira

$$
\text { emsegundo Lugar emseBastiao }
$$

5 daveiga Cabral enao uota em mais [ilegível]

[pellas] nao hauer que seoppusesen Lisboa [8] deIunho

de $1712^{45}$

$$
\text { esendo uistos os seruissos referidos }
$$

eConseserandosse que para o gouerno daCappitania

10 desao Paulo e terras das minas [Conuen] que [aspessoas]

que o auer deser prouido nelle ConCorrao asim

quallidade vallor eprestimo millitar eque

tenha ma[y]or distinCao [e gosto]

\footnotetext{
${ }^{44}$ Acima dessa linha, há a seguinte anotação: São Paulo | 3 - 6 - 712

${ }^{45}$ Seguem rubricas. Abaixo delas, há uma marca redonda do carimbo do Arquivo Histórico Colonial.
} 
Documento 10: parecer escrito em 24 de março de 1714 em Lisboa, acompanhando carta de primeiro de setembro de 1713 escrita em São Paulo

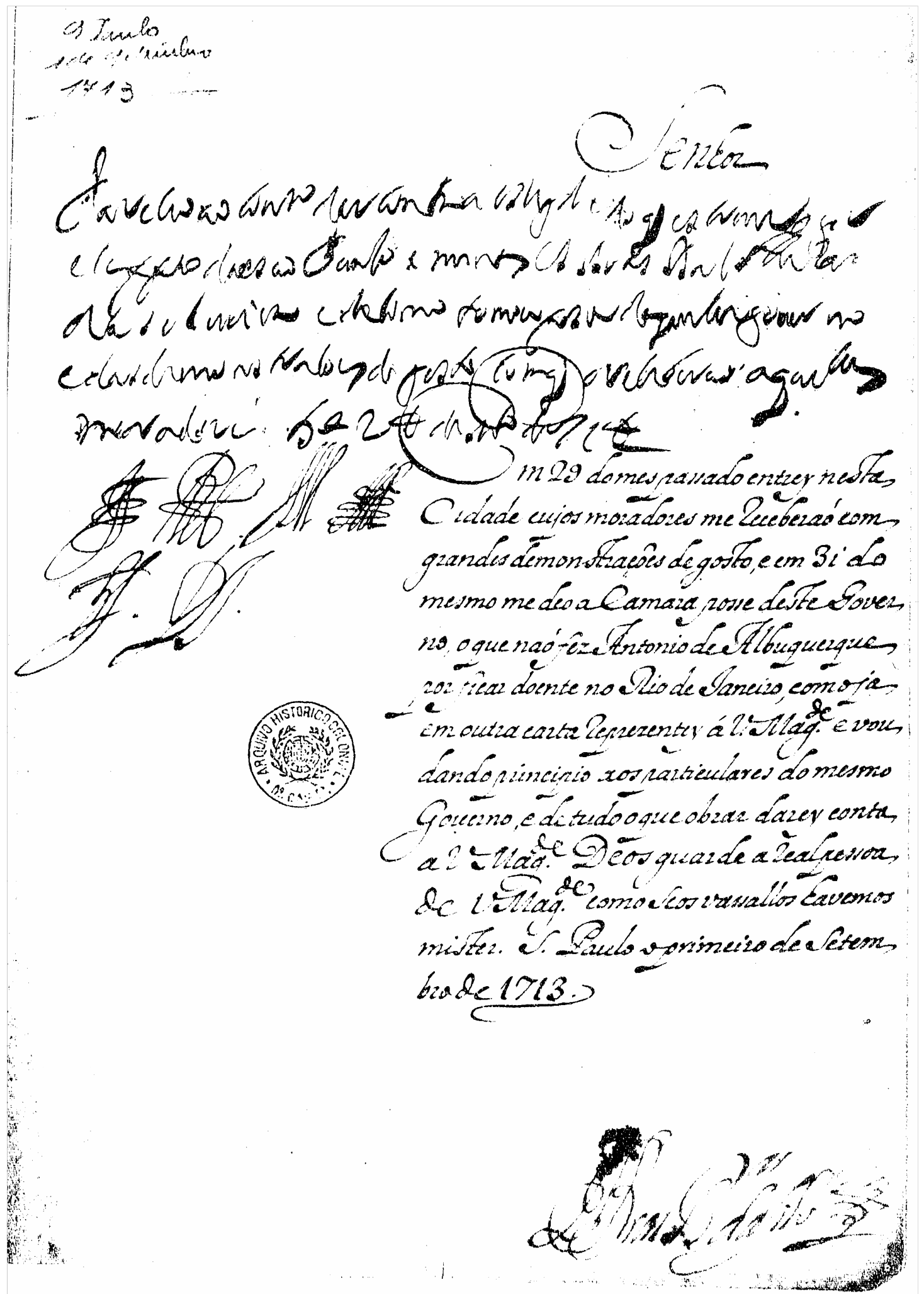




\section{Senhor $^{46}$}

$<$ Pareceo ao Conselho dar Conta a VossaMagestade do que escreve o governador e Cappitao desao Paulo e minas Dom Bras Balthezar da silueira e de Como tomou posse daquelle gouer no

5 e das demonstraCoes de gosto Com que o reCeberaõ aqueles moradores Lisboa 24 deMarco de $714^{47}>$ Em 29 do mes passado entrey nesta

Cidade cujos moradores me receberaõ com grandes demonstrações de gosto, e em 3i do

10 mesmo me deo aCamara posse desteGover no, o que naõ fezAntonio deAlbuquerque por ficar doente no Rio de Ianeiro, comoja ${ }^{48}$ em outra carta reprezentey á VossaMagestade e vou dando principio aos particulares do mesmo

15 Gouerno, e de tudo o que obrar darey conta a VossaMagestade Deos guarde a realpessoa de VossaMagestade como Seos vassallos havemos mister. Sã̃ Paulo oprimeiro de Setem bro de 1713.

\footnotetext{
${ }^{46}$ Na margem superior esquerda, há a seguinte anotação: "São Paulo | 1 de Stembro | 1713”.

${ }^{47}$ Seguem rubricas.

${ }^{48} \mathrm{Na}$ altura dessa linha, na margem esquerda, há uma marca redonda do carimbo do Arquivo Histórico Colonial.
} 
Documento 11: despacho escrito em 9 de agosto de 1718 em Lisboa Ocidental, acompanhando requerimento sem datações cronológica e tópica.

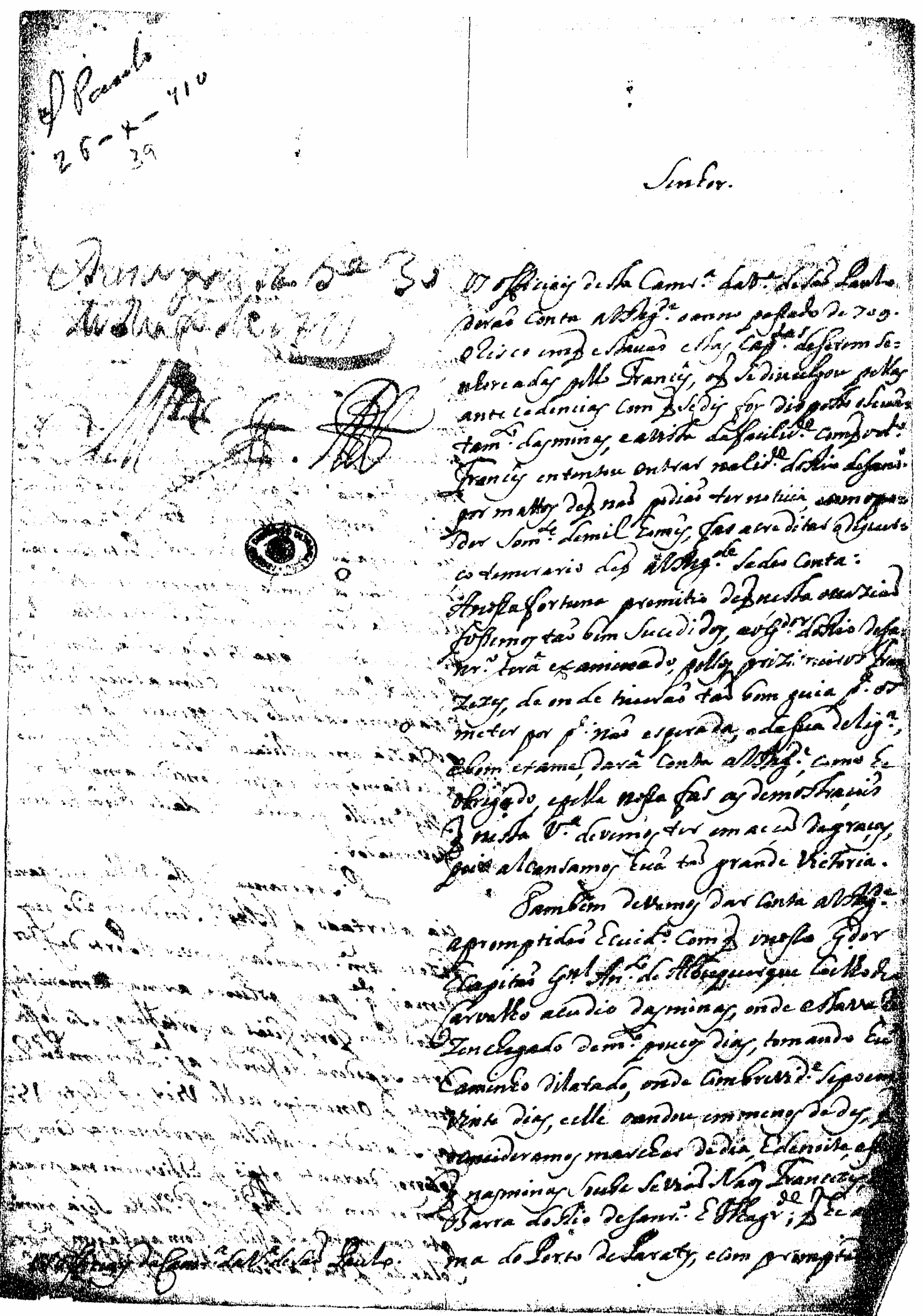


$<$ [Deem] por uista Lisboa 30

Senhor ${ }^{49}$

$<$ de [Iulho] de $\underline{1711^{50}}>$

Os officiais desta Camara daVila de Saõ Paulo

5 deraõ Conta aVossaMagestade o anno passado de 709.

o risco em que estauaõ estas Capitanias deserem $\mathrm{Se}=$

nhoreadas pello Francês, oque Se diuulgou pellas

antecedencias Com que Se dis foy disposto o [Leuã=]

tamento das minas, e avista dafacilidade comque odito

10 Francês ententou entrar naCidade doRio deJaneiro

por mattos deque naõ podiaõ ter noticia, ecom opo=

der Somente de mil homês, fas acreditar o discur $={ }^{51}$

ço temerario deque aVossaMagestade Se deo Conta =

Anossafortuna premitio deque nesta occaziaõ

15 fossemos taõ bem Sucedidos, aoGovernador doRio deJa=

neiro terâ examinado, pellos prizioneiros Fran

zezes, de onde tiueraõ taõ bem guia para os

meter por parte naõ esperada, e dasua deligencia,

ebom exame, darâ Conta a VossaMagestade, Como he

20 obrigado, epella nossa faz as demostraçoĩs

que nesta Vila devemos ter em acçaõ degraças,

pois alcanSamos huã taõ grande Victoria.

Tambem devemos dar Conta a VossaMagestade

apromptidaõ E cuidado Com que onosso Governador

25 E Capitaõ General Antonio de Albuquerque Coelho de

Carvalho acudio das minas, onde estava re

Zenchegado de muito poucos dias, tomando hũ

Caminho dilatado, onde Combrevidade Sepoem

vinte dias, e elle oandou em menos de des, que

30 ocuidaremos marchar de dia, E denoite, es[se]

que nas minas Soube Se viaõ Naos Francezes, [na]

Barra do Rio deJaneiro. E Ilhagrande; quehe a[mes]

$<$ Os officiais daCamara daVila de Sã̃ Paulo> ma do Porto deParaty, e com promptidaõ

\footnotetext{
${ }^{49}$ Na margem superior esquerda, há a seguinte anotação tardia: “São Paulo | 26 - X- 710”.

${ }^{50}$ Seguem rubricas.

${ }^{51} \mathrm{Na}$ altura dessa linha, na margem esquerda, há uma marca oval do carimbo do Arquivo Histórico Ultramarino.
} 
Documento 12: despacho de 8 de julho de 1718 escrito em Lisboa, acompanhando requerimento sem datações cronológica e tópica.

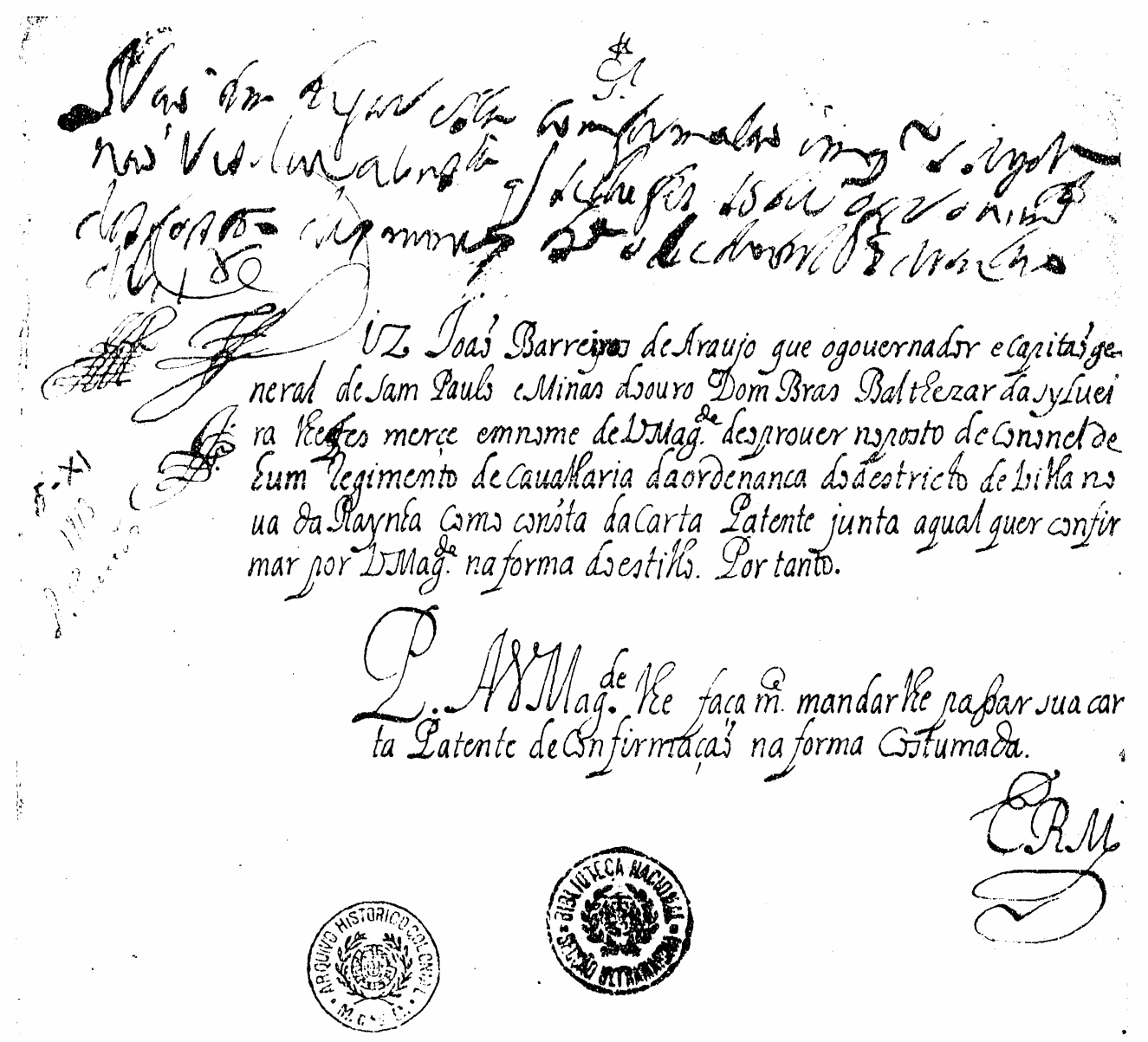




\section{Senhor}

$<$ Naõ tem Lugar esta ComfirmaCao emquanto Sua Magestade

naõ resoluer a Consulta que Selhe fes Sobre o prouimento

dos postos das minas Lisboa ocCidental 8 de iulho

5 de $1718^{52}>$

Diz Ioaõ Barreyros de Araujo que o gouernador e Capitaõ ge

neral de Sam Paulo e Minas do ouro Dom Bras Balthezar da syluei

ra lhefes merçe em nome de VossaMagestade deo prouer no posto de Coronel de ${ }^{53}$

hum regimento de Cauallaria da ordenanca do destricto de villa no

10 ua da Raynha Como consta da Carta Patente junta a qual quer confir

mar por VossaMagestade na forma do estillo. Por tanto.

Pede AVossaMagestade lhe faça merce mandar lhe passar sua car

ta Patente de Confirmaçaõ na forma Costumada ${ }^{54}$

Espera Receber Merce

\footnotetext{
${ }^{52}$ Seguem rubricas.

${ }^{53} \mathrm{Na}$ altura dessa linha, na margem esquerda, há a seguinte anotação: "5-XI | 1718 | São Paulo".

${ }^{54}$ Abaixo, ao lado da abrevitura, há duas marcas redondas de carimbos, um do Arquivo Histórico Colonial, outro da Biblioteca Nacional.
} 
Documento 13: despacho de 12 de agosto de 1719 escrito em Lisboa, acompanha carta de 6 de agosto de 1719, escrita em Santos.

\section{Tom priank to

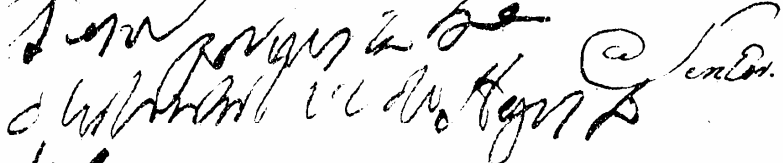
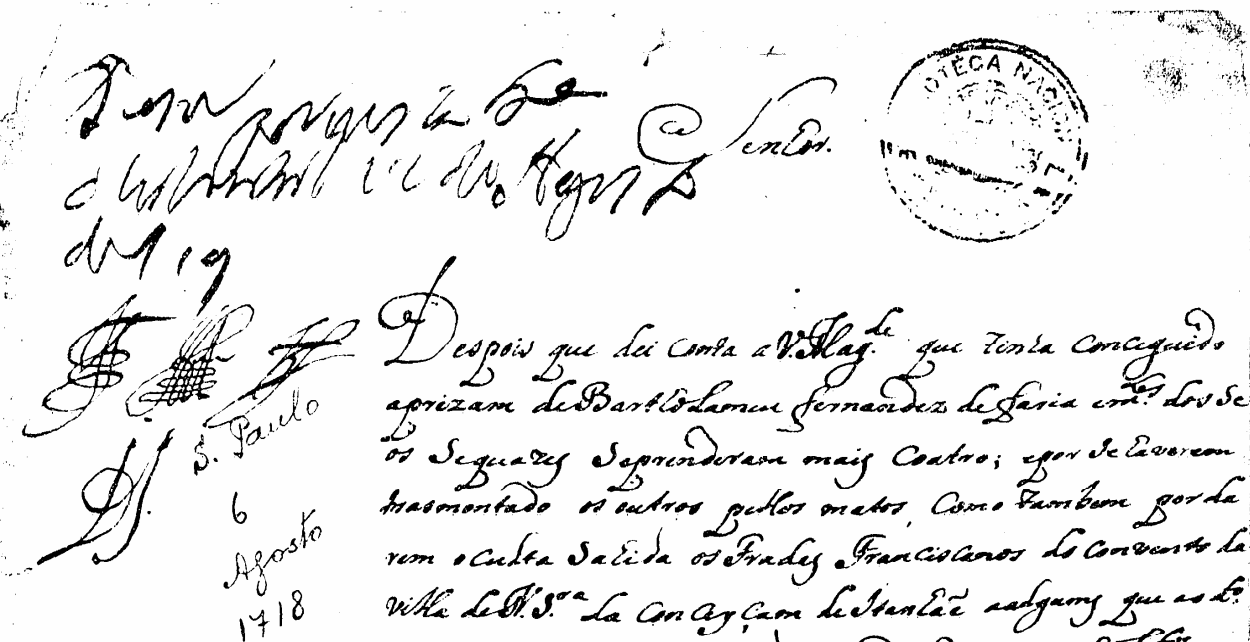

Qf.

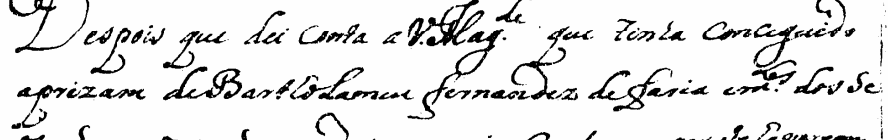

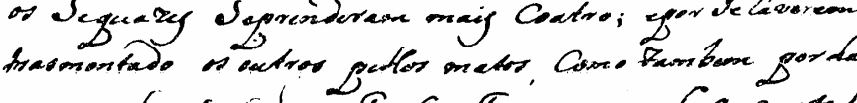

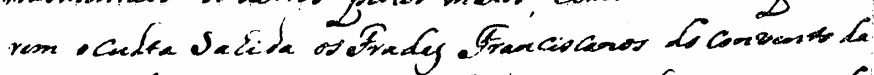

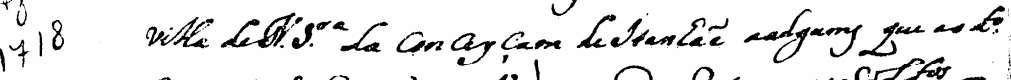

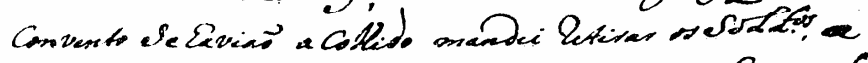

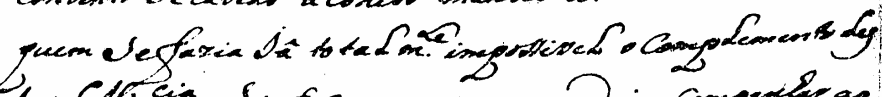

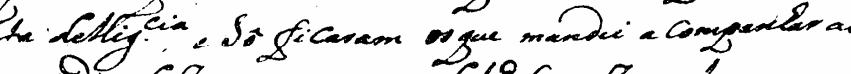

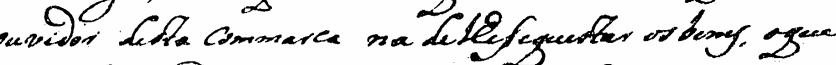

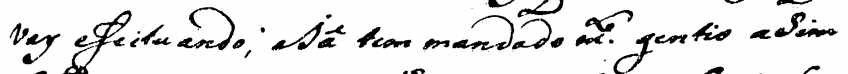

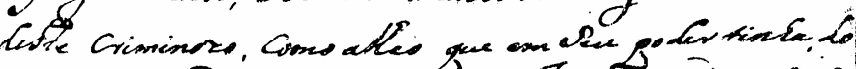

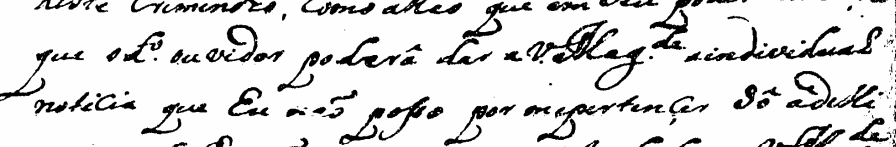

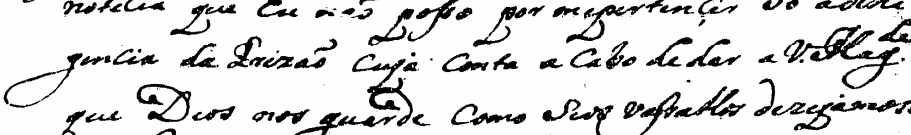

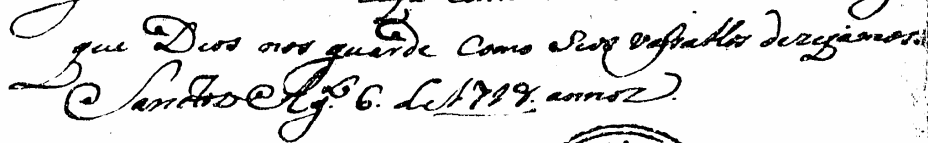

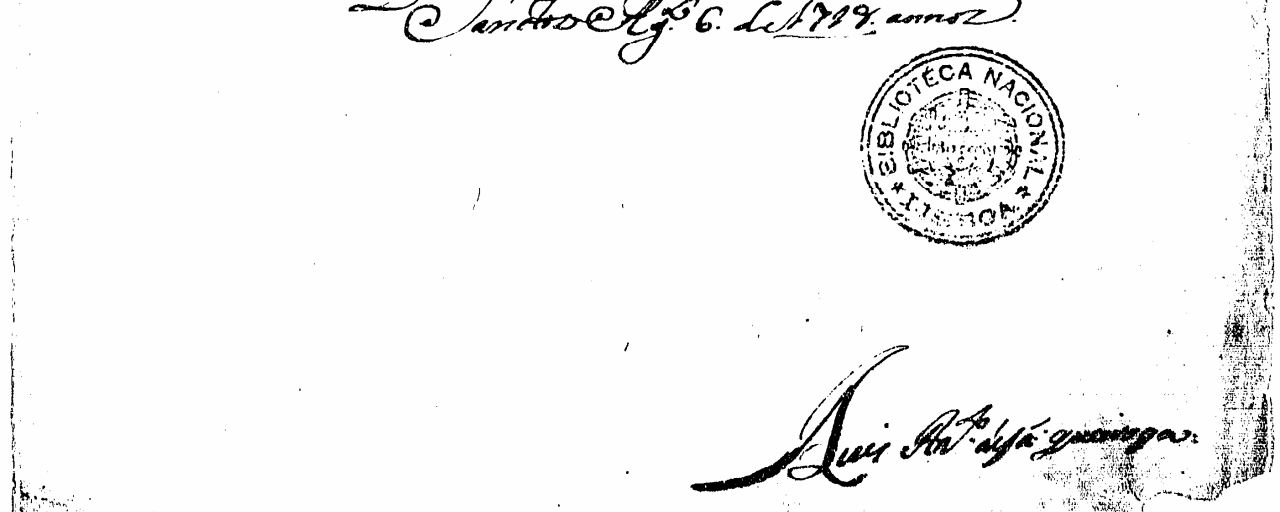

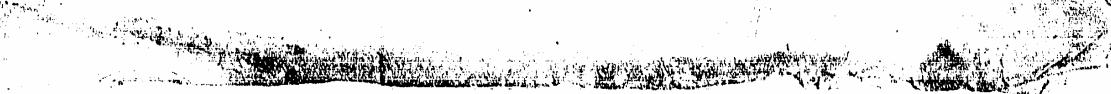




\section{Senhor $^{55}$}

$<$ Resta por uista Lisboa

oCidental 12 de Agosto

de $719^{56}>$

5 Depois que dei Conta a VossaMagestade que tinha ConCeguido

aprizam deBarthoLameu fernandez de faria e muitos dos $\mathrm{Se}^{57}$

os Sequazes Seprenderam mais Coatro; epor Se haverem

trasmontado os outros pellos matos, Como também por da

rem oCuLta Sahida os Frades Franciscanos do Convento da

10 villa deNossa Senhora da ConCepçam de Itanhaẽ aalgums que ao dito

Convento Se haviaõ a Colhido mandei retirar os SoLdados, a

quem Se fazia Iâ totaLmente impossiveL o Complemento des

ta delligencia e Sô fiCaram os que mandei a Companhar ao

ouvidor desta Commarca na delhe sequestar os bems, oque ${ }^{58}$

15 vay efeituando; eIâ tem mandado muito gentio aSim

deste Criminozo, Como alheo que em Seu poder tinha do

que o dito ouvidor poderâ dar a VossaMagestade a individuaL

noticia que Eu naõ posso por mepertenÇer Sô adelli

gencia da Prizaõ Cuja Conta a Cabo de dar a VossaMagestade

20 que Deos nos guarde Como Seos vassallos dezejamos.

SanctozAgosto 6 de $\underline{1718}$ annoz $^{59}$

Luis Antonio desá gueiroga

\footnotetext{
55 À direita do vocativo, há uma marca redonda do carimbo da Biblioteca Nacional.

56 Seguem rubricas.

${ }^{57} \mathrm{Na}$ altura dessa linha, na margem esquerda, há a seguinte anotação: "São Paulo | 6 | Agosto | 1718”.

${ }^{58} \mathrm{Na}$ altura dessa linha, na margem esquerda, há uma marca redonda do carimbo do Arquivo Histórico Colonial.

59 Abaixo, há uma redonda do carimbo da Biblioteca Nacional.
} 


\section{Considerações finais}

Há uma tendência a pensar que a escrita moderna, por tratar-se de prática corrente com a qual todos poderiam estar familiarizados, não necessitaria de aprendizagem especial para ser lida e decifrada, conseqüentemente, sem razão de ser auxiliada por procedimentos paleográficos. Para Glénison (1961) (Apud SPINA, 1977:18), por exemplo, a Paleografia era inútil após 1650, pois, segundo ele, qualquer escrita poderia ser decifrada sem aprendizado especial. No entanto, a que está presente nos documentos do Conselho Ultramarino demonstra que a dificuldade de leitura não reside obrigatoriamente no retrocesso cronológico. Esse tipo de escrita pode oferecer a mesma, ou até maior dificuldade do que a de tempos remotos.

A análise paleográfica, composta essencialmente pelo levantamento detalhado de seu alfabeto, e a comparação com os dados de detecção de mãos inábeis trabalhados por Marquilhas demonstraram que os aspectos que oferecem dificuldade de leitura não são decorrentes apenas da falta de habilidade do escriba, pode ser conseqüência também da velocidade empregada no processo de escrita, fazendo com que o traçado de seus elementos gráficos seja simplificado ou deformado. Exemplos dessa prática são as várias formas que uma letra assume em determinado contexto, como o $<$ r $>$ que se assemelha a um $<$ v $>$ quando em meio de palavra, ao perder parte de seu traçado inicial.

O levantamento do alfabeto e a sua descrição detalhada, acompanhando o trajeto de formação de cada letra, desenvolvendo as abreviaturas e estudando os nexos, representam etapas essenciais na eliminação de pendências causadas pela dificuldade de leitura. Ao se fazer um levantamento como este, o editor adquire um olhar paleográfico que o muni de mecanismos para o conhecimento da lógica da escrita, entendem-se as tendências do escriba para cada elemento gráfico, além de conseguir explicar as suas variações quanto às formas e aos traçados em diversos contextos. 
Espera-se que, com este trabalho, tenha-se oferecido subsídios para os estudos sobre a escrita do século XVIII, pois é rara a localização de bibliografia que dê conta da produção gráfica desse e de outros séculos. As obras encontradas tratam da história dos tipos de escrita e, entre outras discussões, apresentam seus respectivos alfabetos. Essa apresentação, grosso modo, é composta por formas padronizadas cuja representação se limita a um número muito reduzido de exemplos em comparação com a variação sofrida sob os punhos de diversos escribas. Mesmo quando isso acontece, geralmente, não vêm acompanhados pela indicação da fonte. Em geral, não explicam, com precisão, as formas assumidas nos documentos.

Visitando arquivos, institutos e bibliotecas que possuem manuscritos em seus acervos, observa-se um número considerável de documentos que, de tão deteriorados por papirófagos, ou até mesmo por falta de conservação, têm poucas chances de fazerem parte do corpus de quaisquer pesquisas. Se a dificuldade de leitura oferecida pela escrita de determinados manuscritos representar um empecilho a mais que os coloquem no mesmo patamar que os primeiros, cada vez menos, servirão como base para pesquisas lingüísticas, por conseguinte, a matéria ali discutida também será facilmente perdida.

Não há como negar que, em determinados casos, o estado da letra, do papel ou da tinta de qualquer documento represente um dos principais fatores para excluí-lo de qualquer corpus. Por essa razão, a análise paleográfica da escrita presente nos documentos do Conselho Ultramarino, acompanhada do levantamento meticuloso de seu alfabeto e da edição semidiplomática, vem à tona para desmistificar o que até então tem impedido que esse tipo de testemunho conste do corpus de muitos trabalhos filológicos. Tenta mostrar que por meio da utilização de procedimentos paleográficos é possível realizar a sua leitura e transcrição. 


\section{Bibliografia}

ACIOLI, Vera Lúcia Costa. A escrita no Brasil Colônia: um guia para leitura de manuscritos. 2. ed., Recife, Fundação Joaquim Nabuco, Editora Massanga, 2003.

ARRUDA, José Jobson de Andrade (coord.). Documentos manuscritos avulsos da Capitania de São Paulo : (1644-1830). São Paulo: EDUSC, 2000.

BLANCHE-BENVENISTE, Claire. Les unités: langue écrite, langue orale, In: Clotilde PONTECORVO E Claire BLANCHE-BENVENISTE (eds.) Proceeding of the Workshop on Orality versus Literaracy: Concepts, Methods and Data. Siena Italy: Estrasburgo: European Science Foundation, 1992, p. 133-194.

CAETANO, Marcelo. O Conselho Ultramarino: esboço da sua história. Lisboa: Agência Geral do Ultramar. 1967.

CAMBRAIA, César Nardelli. Introdução à crítica textual. São Paulo: Martins Fontes, 2005.

CUnHA, A.G., CAMBraiA, C. N., MEGAle, H. A Carta de Pero Vaz de Caminha. São Paulo: Humanitas Publicações, FFLH, USP, 1999.

FACHIN, Phablo Roberto Marchis. História nos manuscritos: conflito entre poder local e religiosos na Vila de Santos. Estudos Lingüísticos. São Paulo:, p.1584 - 1590, 2006.

FACHIN, Phablo Roberto Marchis. O português da chibata: relato do escrivão, que chicoteou um escravo e depois foi açoitado num convento, recupera costumes e falas coloniais. Revista Língua Portuguesa. São Paulo, p.56 - 57, 2005.

FIGUEIREDO, Manuel de Andrade de. Nova escola para aprender a ler, escrever, e contar: primeira parte. Lisboa Occidental: Officina de Bernardo da Costa de Carvalho, 1722.

FLEXOR, Maria Helena. Abreviaturas: manuscritos dos séculos XVI ao XIX. $2^{\mathrm{a} e d .}$ São Paulo: Edições Arquivo do Estado, 1991.

GLÉNISON, Jean. Iniciação aos estudos históricos. São Paulo: Difusão Européia do Livro, 1961. 
HIGOUNET, Charles. História Concisa da Escrita. Trad. 10 ed. Marcos Marciolino. São Paulo: Parábola Editorial, 2003.

HOUAISS, Antônio e VILLAR, Mauro de Salles. Dicionário Houaiss da Língua Portuguesa. Rio de Janeiro: Editora Objetiva, 2001.

MAIA, Clarinda de Azevedo. História do Galego-Português: estado lingüístico da Galiza e do Noroeste de Portugal desde o século XIII ao século XVI. Coimbra: Instituto Nacional de Investigação Científica, 1986.

MALLON, Jean. Paléographie Romaine. Madrid: Consejo Superior de Investigaciones Científicas / Instituto Antonio de Nebrija de Filologia, 1952.

MARQUILHAS, Rita. A Faculdade dasLetras. Lisboa: Imprensa Nacional-Casa da Moeda, 2000.

MARTÍNEZ, Tomáz Marín. Paleografía y Diplomática. Madrid: Universidad Nacional De Educación a Distancia, 1991.

MARTINHEIRA, José Joaquim Sintra (org.). Catálogo dos Códices do Fundo do Conselho Ultramarino Relativos ao Brasil existentes no Arquivo Histórico Ultramarino. Lisboa: Fundação Calouste Gulbenkian, 2001.

MEGALE, H. Pesquisa Filológica: Os Trabalhos da Tradição e os novos trabalhos em Língua Portuguesa. In: Seminário do Grupo de Estudos Lingüísticos do Estado de São Paulo (GEL), 1998, Campinas. Estudos Lingüísticos XXVII. Campinas: Editora da UNICAMP, 1998. v. 1. p. 3-28.

MENDES, Ubirajara Dolácio. Noções de Paleografia. São Paulo: Departamento do Arquivo do Estado de São Paulo/Secretária da Educação, 1953.

PETRUCCI, Armando (org.). Libri, scrittura e pubblico nel Rinascimento. Guida storica e critica. Roma-Bari: Laterza, 1979. 
SANTOS, Maria José Azevedo Santos. Da visigótica à carolina: a escrita em Portugal de 882 a 1172 (aspectos técnicos e culturais). Lisboa: Fundação Calouste Gulbenkian: Junta Nacional de Investigação Científica e Tecnológica, 1994.

SILVEIRA, Cláudia Damião Lopes. Edição de textos relativos à defesa, segurança e fiscalização portuária da Baixada Santista no período final do século XVIII e início do século XIX. São Paulo, 2004. 252f. Dissertação (Mestrado em Letras). Faculdade de Filosofia, Letras e Ciências Humanas, Universidade de São Paulo.

SPINA, Segismundo. Introdução à Edótica: crítica textual. São Paulo: Cultrix, 1977.

TEYSSIER, Paul. História da Língua Portuguesa. Trad. Celso Cunha. 2a ed. São Paulo: Martins Fontes, 2001.

TOLEDO NETO, Sílvio de Almeida. Variação grafemática consonantal no livro de José de Arimatéia (cod. ANTT643). São Paulo, 1966. 107f. Dissertação (Mestrado em Letras). Faculdade de Filosofia, Letras e Ciências Humanas, Universidade de São Paulo. 